\title{
How and Why Upper Colorado River Basin Land, Water, and Fire Managers Choose to Use Drought Tools (or Not)
}

Open-File Report 2018-1173 



\section{How and Why Upper Colorado River Basin Land, Water, and Fire Managers Choose to Use Drought Tools (or Not)}

By Amanda E. Cravens

Open-File Report 2018-1173 


\section{U.S. Department of the Interior \\ RYAN K. ZINKE, Secretary}

\section{U.S. Geological Survey James F. Reilly II, Director}

\section{U.S. Geological Survey, Reston, Virginia: 2018}

For more information on the USGS - the Federal source for science about the Earth, its natural and living resources, natural hazards, and the environment-visit https://www.usgs.gov or call 1-888-ASK-USGS.

For an overview of USGS information products, including maps, imagery, and publications, visit https://store.usgs.gov.

Any use of trade, firm, or product names is for descriptive purposes only and does not imply endorsement by the U.S. Government.

Although this information product, for the most part, is in the public domain, it also may contain copyrighted materials as noted in the text. Permission to reproduce copyrighted items must be secured from the copyright owner.

Suggested citation:

Cravens, A.E., 2018, How and why Upper Colorado River Basin land, water, and fire managers choose to use drought tools (or not): U.S. Geological Survey Open-File Report 2018-1173, 60 p., https://doi.org/10.3133/ofr20181173. 


\section{Acknowledgments}

This project was funded and supported by the U.S. Geological Survey Mendenhall program, the Department of the Interior North Central Climate Adaptation Science Center, and the Fort Collins Science Center Social and Economic Analysis Branch. The study objectives were jointly developed with Nolan Doesken and the Colorado Climate Center. Alicia Marrs and Chad McNutt of the National Integrated Drought Information System and Elizabeth McNie, Jeff Lukas, and Ursula Rick of Western Water Assessment at the University of Colorado provided useful input into the research design. The project benefited from the intellectual and personal connections between this project and two related drought projects, the "Advancing the Use of Drought Early Warning Systems in the Upper Colorado River Basin" project led by Ben Livneh and Lisa Dilling, and the Science for Nature and People Partnership Ecological Drought Working Group led by Shawn Carter, Molly Cross, and Kimberly Hall. The author would like to thank all the water, land, and fire managers who generously shared their experiences and perspectives regarding drought information in the Upper Colorado River Basin. She would also like to thank Nina Burkardt, Adam Wilke, Jeff Lukas, Theresa Jedd, Jack Friedman, Rebecca Page, Nicola Ulibarri, Rebecca Nelson, and Anne Siders for comments on earlier versions of this research and report. 


\section{Contents}

Acknowledgments ..........................................................................................................................ii

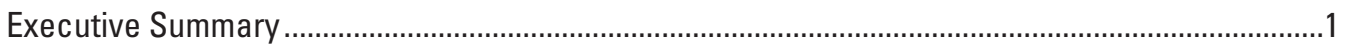

1 Introduction ................................................................................................................

1.1 Role of Drought Early Warning Systems (DEWS) in Drought Preparedness ....................3

1.2 Drought in the Upper Colorado River Basin .................................................................

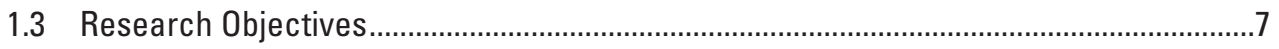

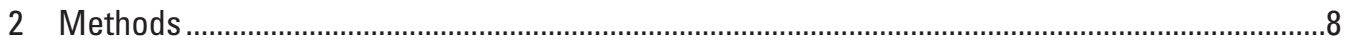

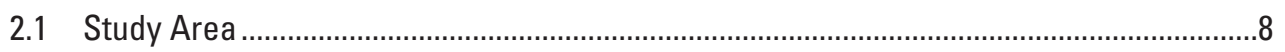

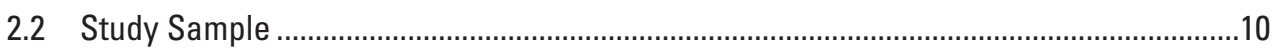

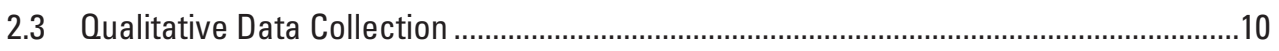

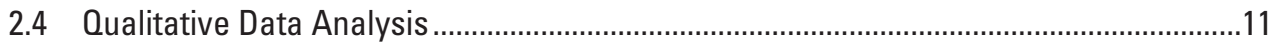

3 Managing for Drought in the Upper Colorado River Basin .....................................................12

3.1 Resource Management Decisions Impacted by Drought in the UCRB..........................12

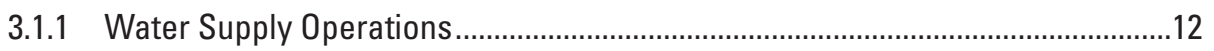

3.1.2 Ecological Health and Resiliency ................................................................12

3.1.3 Rangeland Management...............................................................................13

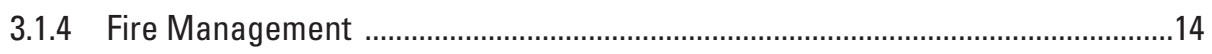

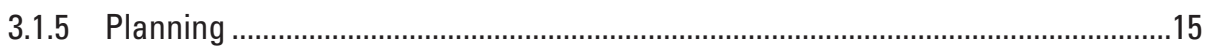

3.1.6 Other Drought Impacts ..............................................................................15

3.1.7 Participants Who Do Not Manage for Drought As Such...................................16

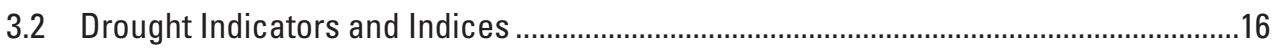

3.3 Inductively-Derived "Profiles" of Drought Managers ......................................................33

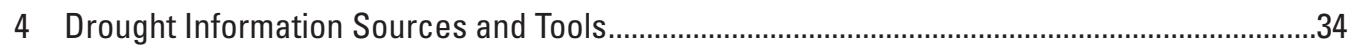

4.1 A Note About Use of Drought Information ....................................................................

4.2 Drought Information Sources on Which Managers Rely …………...............................35

4.3 Using or Not Using Common Information Categories .....................................................35

5 Selecting Among Available Drought Tools............................................................................

5.1 How Managers Find Out About Drought Information and Tools .....................................4

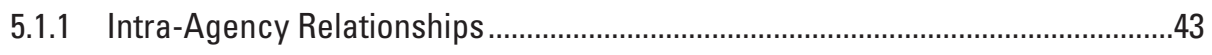

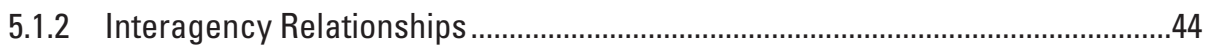

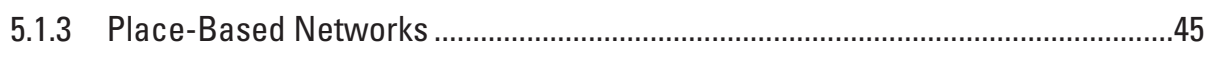

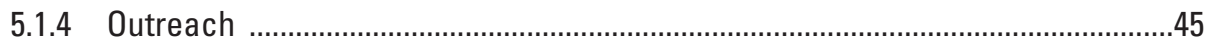

5.1.5 Breakdowns in the Flow of Knowledge About Tools .........................................45

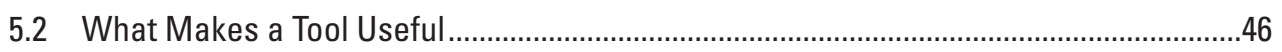

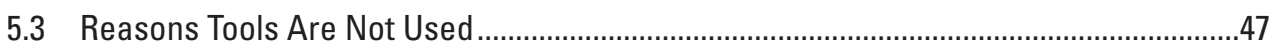

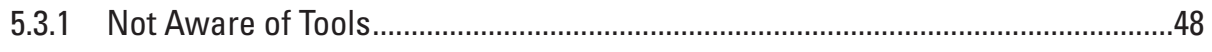

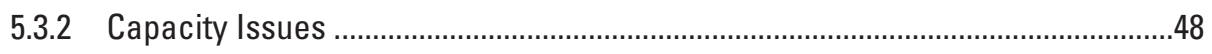

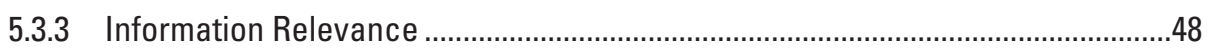

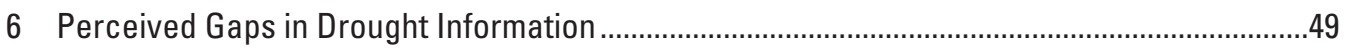

$6.1 \quad$ Higher Resolution Monitoring Data ........................................................................ 49

6.2 Gaps in Scientific Understanding of Drought and its Impacts ......................................50

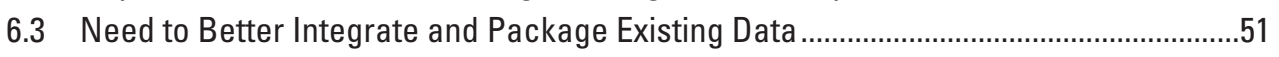


7 Conclusion - Summary of Key Findings and Implications ……...............................................51

7.1 Designing for Five Types of Drought Decision Makers with Distinct Information Needs

7.2 Supporting Users Within an "Ecosystem" of Drought Information Sources, Products, and Tools in the UCRB .............................................................................52

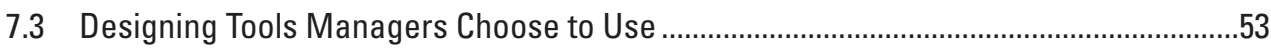

7.4 Using Existing Networks to Optimize Outreach Efforts...................................................53

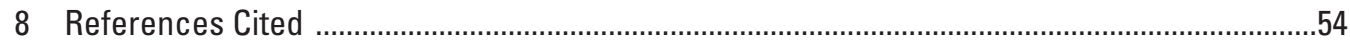

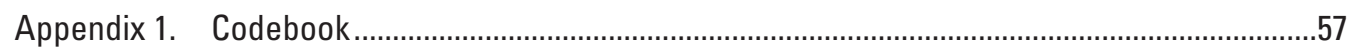

Section 3. Managing for Drought in the Upper Colorado River Basin.......................................57

Section 4. Drought Information Sources and Tools ..............................................................58

Section 5. Selecting From Among Available Tools ...................................................................59

Section 6. Perceived Gaps in Drought Information ...................................................................60

\section{Figures}

1. Map showing National Integrated Drought Information System regional drought early warning systems ....................................................................................................

2. Map showing annual precipitation in the Colorado portion of the Upper Colorado River Basin

3. Graph showing fraction of Colorado in multiyear drought, based on the 48-month Standardized Precipitation Index, 1890-2012

4. Map showing Colorado Water Divisions and Federal land management units on the Colorado Western Slope, used as the sampling frame for the study ......................

5. Graph showing summarized use of drought information by user profile ..........................35

\section{Tables}

1. Drought indicators reported by respondents........................................................18

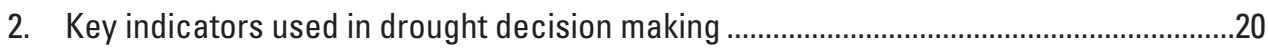

3. Decision context and timing, key indicators, and key information sources

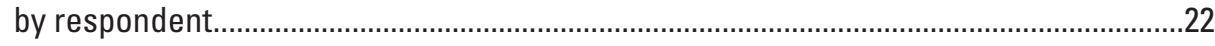

4. Drought information sources used by different user types..............................................37

5. Perceived gaps in drought information by user profile type ............................................49 


\section{Abbreviations and Acronyms}

\begin{tabular}{|c|c|}
\hline BLM & Bureau of Land Management \\
\hline $\mathrm{CCC}$ & Colorado Climate Center \\
\hline CBRFC & Colorado Basin River Forecast Center \\
\hline DEWS & drought early warning system \\
\hline DOI & Department of the Interior \\
\hline DSS & decision support system \\
\hline DWR & Colorado Division of Water Resources \\
\hline FERC & Federal Energy Regulatory Commission \\
\hline IMW & Intermountain West \\
\hline NCCASC & North Central Climate Adaptation Science Center \\
\hline NIDIS & National Integrated Drought Information System \\
\hline NEPA & National Environmental Policy Act \\
\hline NOAA & National Oceanic and Atmospheric Administration \\
\hline NPS & National Park Service \\
\hline NRC & National Research Council \\
\hline NRCS & Natural Resources Conservation Service \\
\hline NWS & National Weather Service \\
\hline RAWS & remote automatic weather stations \\
\hline Reclamation & Bureau of Reclamation \\
\hline RMCC & Rocky Mountain Area Coordination Center \\
\hline SNOTEL & snow telemetry \\
\hline SPI & Standard Precipitation Index \\
\hline SWE & snow-water equivalent \\
\hline SWSI & Surface Water Supply Index \\
\hline UCRB & Upper Colorado River Basin \\
\hline USFS & United States Forest Service \\
\hline USGS & United States Geological Survey \\
\hline USFWS & United States Fish and Wildlife Service \\
\hline WAPA & Western Area Power Administration \\
\hline WWA & Western Water Assessment \\
\hline
\end{tabular}




\title{
How and Why Upper Colorado River Basin Land, Water, and Fire Managers Choose to Use Drought Tools (or Not)
}

\author{
By Amanda E. Cravens
}

\section{Executive Summary}

On the Western Slope of Colorado, variable climate and precipitation conditions are typical. Periods of drought—which may be defined by lack of water, high temperatures, low soil moisture, or other indicators - cause a range of impacts across sectors, including water, land, and fire management.

U.S. Congress created the National Integrated Drought Information System Act of 2006 (NIDIS; Public Law 109-430) within the National Oceanic and Atmospheric Administration (NOAA) with an interagency mandate "to coordinate and integrate drought research, building upon existing Federal, Tribal, State, and local partnerships in support of creating a national drought early warning information system (NIDIS, 2016)".

The Upper Colorado River Basin (UCRB) was one of the first pilot areas in which NIDIS implemented a drought early warning system (DEWS) in 2009. NIDIS presently supports eight regional DEWS; as of 2016, the UCRB DEWS has been incorporated into an expanded Intermountain West (IMW) DEWS. The selection of the UCRB for an initial DEWS reflects the regional importance of drought information for managing water supply for agriculture and other uses, and the need for effective decision support related to drought. Additionally, new drought information products were developed specifically for the UCRB DEWS, and a number of others have been created since 2009, adding to the preexisting toolkit for drought decision making.

The various elements of the UCRB drought early warning system can be expected to be more or less suitable for the needs of different decision makers. As a result, the UCRB makes an ideal case study to examine the use of scientific information products and tools in which the broad decision context (managing drought) is defined, but information needs of current and prospective users vary. Thus decision makers will make varied choices about which of the available tools to use or not use, depending on the particular management and institutional context in which they work. The author aimed to identify factors that affect the choices of decision makers about whether and how to use particular information sources, products, and tools. The investigation focused on the following research questions:

- What decisions do managers make related to drought in the Upper Colorado region and particularly the Western Slope of Colorado? About which impacts of drought are they most concerned?

- What indicators and information products do decision makers rely on to manage for the impacts of drought in this region?

- How do decision makers find out about and choose between available drought information sources, products, and tools?

- What gaps (if any) do they perceive in currently available drought information and tools?

In both its definition of drought information and decision support tools and in its sampling design, the author deliberately took a broad approach. The author intentionally defined information sources, products, and tools broadly. The goal was to document as many sources of information as possible that respondents reported using to assist in preparing for, responding to, or managing the impacts of drought. A range of information products and tools were identified, ranging from monitoring datasets (for example, SNOTEL network), to modeling tools (for example, USGS StreamStats), to web portals or dashboards (for example, Western Water Assessment [WWA] Dashboard). Other kinds of information sources also appear, ranging from manager reliance on other people to use of scientific research to mental models based on experiential knowledge (Section 4). In this study, the author collectively considers these information sources, products, and tools as decision support. The project investigated how and why information sources and tools for understanding weather, climate, precipitation, and drought impacts are used by managers on the Colorado Western Slope. 
Studies of decision support tools or information sources often concentrate on the known users of a given tool(s). Such an approach can yield useful information; it provides rich insight into the experiences of users and can suggest design modifications to make existing tools more effective. Yet it is not an effective approach to capture the perspectives and needs of prospective tool users or to investigate the factors that affect whether or not someone chooses to use tools in the first place. Essentially, sampling based on known tool users is a case of sampling on the dependent variable (tool use) (Geddes, 1990). In the case of the UCRB DEWS, the known tool users represent known participants in the DEWS network, but the challenge was to identify those who might benefit who were not currently participating. To overcome this challenge, in this study the author instead used a geographically based sampling strategy (Section 2.2) in which a range of natural resource managers from preidentified Federal management units and selected State agencies on the Western Slope were considered prospective users of tools. Prospective users were then asked to describe in an open-ended fashion what information and tools they do or do not use and why. This approach allowed for respondents to report both use and nonuse of tools, and thus the ability to identify factors that influence information and tool use choices by managers.

The report is presented in seven main sections. The Introduction sets the context, considering the need for drought information and the goals of drought early warning systems. It then describes drought in the UCRB region. Section 2 describes the design and methods of the study.

Section 3 addresses the question of who manages for drought impacts in the UCRB. The intentionally broad sampling strategy of the study resulted in conversations with a wide range of State and Federal managers, who work under a variety of regulatory frameworks and manage a variety of natural resources. As a result, they are concerned about a wide range of drought impacts and use a corresponding wide range of indicators to understand the state of their resources of concern. This section captures the range of variability, while grouping together decision makers who share similar concerns and make use of similar indicators. The range of decision contexts and indicators emphasizes that views of drought held by managers are shaped by the way drought conditions affect the resources for which they are responsible. Understanding the information needs of a manager requires first understanding the decision space in which the manager operates, as this decision space determines the indicators of concern and the timeframe of information needed.

Section 4 turns to the tools and information sources on which decision makers rely. It links the indicators described in the previous section to specific sources of data and information, describing the agencies, websites, and people on which managers depend to understand and manage for drought. A key theme that emerges in this section is redundancy: the same underlying datasets are often accessed in different ways by different individuals.

Section 5 reports results of how managers find out about available tools or information sources and how they evaluate usability of tools. One key difference that emerges is the strong horizontal network among water management agencies juxtaposed with the tendency for information to move vertically within the land management agencies. Almost all participants in the study agreed on the basic factors that affect tool usability: something that is easy to use and relevant to their management challenges, though their specific decision contexts determined what those challenges might be. Section 6 then addresses perceived gaps in drought information and tools; the most-often-mentioned gap in drought information was soil moisture information for the right scale and locations to meet particular needs of managers.

Section 7 presents key findings and implications. First, based on analysis of their drought impacts and indicators of interest (Section 3), the information sources on which they rely (Section 4), and the information networks and communities of practice to which they belong (Section 5), respondents were inductively classified into five "profiles" or types of drought managers: water supply managers, rangeland managers, ecological managers, fire managers, and those who are not actually managing for drought, despite having responsibilities related to water. These profiles provide an answer to the remark by Redmond (2002, p.1,147) that droughts are like rainbows, with everyone experiencing their own version. In the UCRB, drought impacts appear to come in distinct flavors that can be viewed as analogous to the colors of the rainbow, even if each individual might experience a slightly different shade of green or brown. They suggest that drought information providers should consider the distinct information needs of their audience(s) in designing information products and tools. Second, drought indicators and sources in the UCRB form an information ecosystem with overlap. This redundancy appears beneficial, as managers may access the same dataset through different websites or portals. Third, respondents emphasized information sources and tools are used when they are salient and credible, suggesting that information providers need to consider salience as well as technical credibility in tool design. Finally, water managers described a robust interagency community of practice that kept them informed about new information sources while land and fire managers relied primarily on intra-agency relationships to stay informed. These differences in how respondents reported finding out about tools and information sources suggest different outreach strategies are needed for information providers who want to reach these groups of managers. 


\section{Introduction}

\subsection{Role of Drought Early Warning Systems (DEWS) in Drought Preparedness}

Drought is a pervasive, widespread natural hazard that causes significant damages, but it can be challenging to define (Wilhite and Vanyarkho, 2000). The existence of drought depends both on a hydrological or meteorological hazard-generally defined as deviation from a baseline condition of "normal" water availability - and on the inability of those exposed to withstand such a hazard (Agnew and Warren 1996; Wilhite, Svoboda, and Hayes, 2007). At the most basic level, drought can be defined as "insufficient water to meet needs" for a given purpose or in a given region (Redmond 2002, p. 1,144). Drought has been called the "creeping" natural hazard; its stopping and starting points may be difficult or even impossible to identify except in retrospect (Wilhite and Vanyarkho, 2000).

Further complicating the question of definitions is the fact that individuals, communities, and economic sectors experience drought through its wide variety of impacts, including direct and indirect economic, environmental and social impacts. Drought "produces a complex web of impacts that not only ripple through many sectors of the economy but may be experienced well outside the affected region, extending even to the global scale" (Wilhite and Vanyarkho, 2000, p. 247). In the heavily humanmodified watersheds and riverscapes of 21st century North America, meteorological, hydrological, environmental, and social causes and impacts of drought are tightly interrelated and often feed into one another (Van Loon and others, 2016).

Another way to approach the challenge of defining drought is through the monitoring of specific indicators. A particular threshold level of a particular indicator variable for a particular period of time can be used to define what is normal, what represents drought onset, and what represents drought recovery (Steinemann, Iacobellis, and Cayan, 2015). As a result, drought monitoring and the availability of accurate, timely information about the status of indicator variables is a key element of an effective strategy for preparing for and responding to drought; knowing the value of an indicator variable helps mark drought onset and recovery as well as guide response during the drought itself. Yet given the diverse impacts that drought can manifest, there are no "one size fits all" indicators that apply in every situation. Thus an effective drought early warning system (DEWS) incorporates a range of monitoring approaches and indicators that provide information pertaining to the relevant impacts of drought in the region in which it is being implemented (Wilhite, Sivakumar, and Wood, 2000; Heim, 2002; World Meteorological Organization (WMO) and Global Water Partnership (GWP), 2016). Redmond (2002, p. 1147) summarized the need for multiple ways of monitoring and depicting drought: "Drought is a many-headed creature, and its full description requires an equally diverse menagerie of indices and indicators."

In the United States, the National Oceanic and Atmospheric Administration (NOAA) National Integrated Drought Information System (NIDIS; http:/www.drought.gov) program facilitates, convenes, and funds regional DEWS, each of which is comprised of a range of partner organizations. Authorized by Congress in 2006, the NIDIS mandate is "interagency coordination and integrated drought research that builds upon existing federal, tribal, state, and local partnerships to create a national drought early warning system (DEWS)." NIDIS is working toward the eventual goal of a national DEWS by supporting a network of regional DEWS (fig. 1). Each regional DEWS provides climate and drought information and is made up of "relevant partners and community members across its region, including universities, the private sector, and Federal, Tribal, State, and local entities. Stakeholders participate in the NIDIS consultation process, and they support NIDIS priorities by leveraging existing resources, programs, and partnerships" (NIDIS 2017, p. 3).

The NIDIS 2017-2018 Strategic Plan for the Intermountain West (IMW) DEWS describes the evolution of drought early warning in the Nation and the importance of the Upper Colorado River Basin, which is the geographical focus of this report (Section 1.2 and 2.1):

"NIDIS launched the Upper Colorado River Basin (UCRB) DEWS in 2009; the UCRB was the first pilot DEWS in the nation. Following a series of stakeholder engagement meetings, interviews, and an in-depth gaps assessment in 2009-2010, the Colorado Climate Center (CCC) at Colorado State University became a key partner in implementing the UCRB DEWS. In response to the feedback during this scoping process, and in an effort to avoid, or at least mitigate the impacts associated with the drought of 2002, the CCC, NIDIS, and other State and local partners began a proactive monitoring process which evolved into the UCRB weekly drought assessments. These assessments, now posted weekly on the CCC website and delivered regularly by webinar, not only provide Upper Basin stakeholders with timely information on drought and climate information and forecasts, but also foster a dialogue that helps shape the region's weekly recommendations to the U.S. Drought Monitor.

The importance and popularity of these regular monitoring and forecasting activities was further magnified during the 2012 drought. Since that time, the UCRB weekly drought assessments have become a model for consistent and easily digestible dissemination of drought and climate information in the region. 


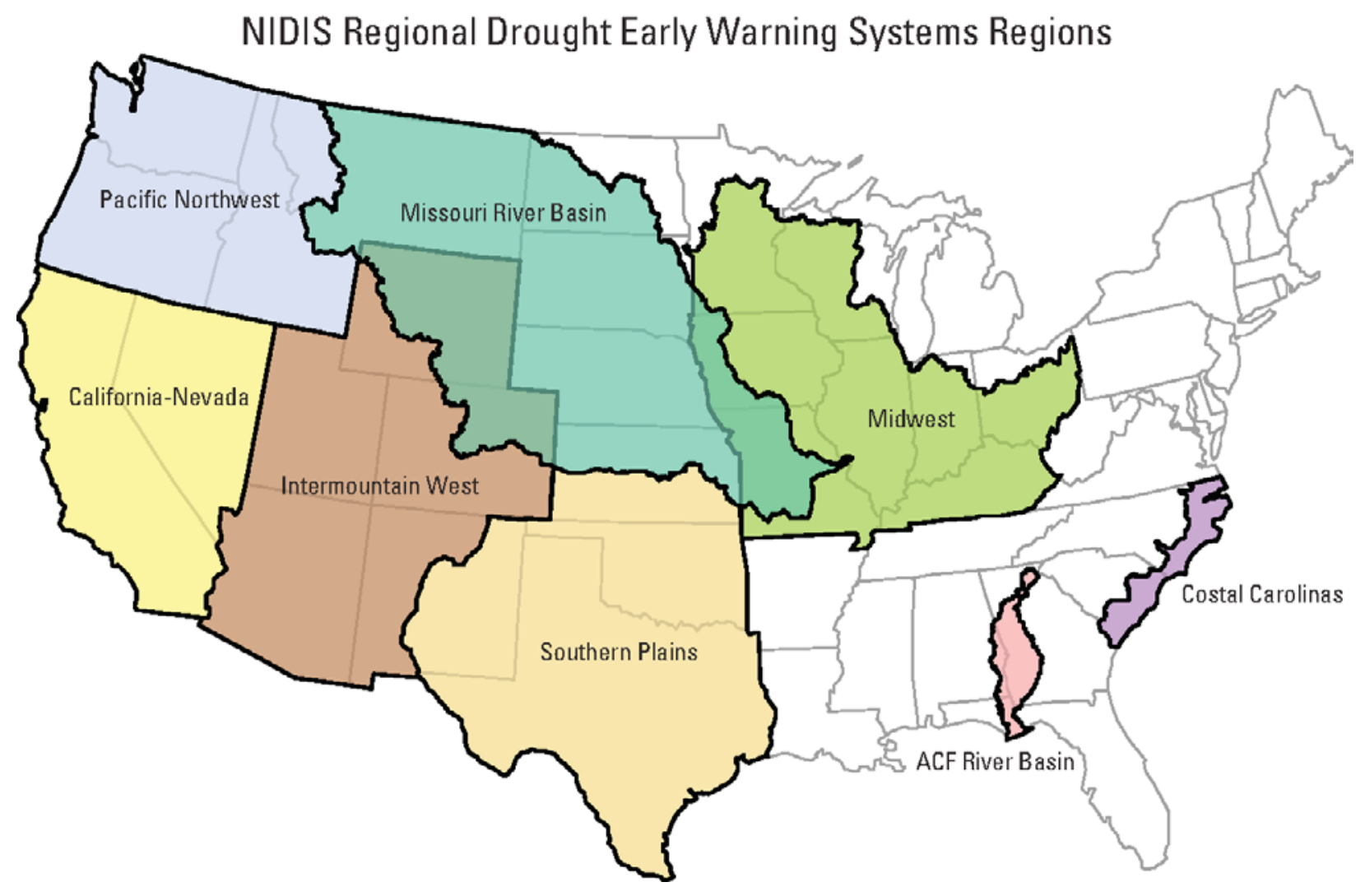

Figure 1. National Integrated Drought Information System (NIDIS) regional drought early warning systems (DEWS).

In 2016, the Upper Colorado River Basin (UCRB) DEWS and the Four Corners Tribal Lands DEWS were combined to form the Intermountain West (IMW) DEWS. The IMW DEWS boundary expanded to include Arizona, Colorado, Utah, Wyoming, and western New Mexico. (NIDIS 2017, p. 4)"

From 2009 to present, then, the UCRB has been central to the NIDIS mandate to facilitate drought early warning. Their main partners in this effort, the Colorado Climate Center, were a key impetus behind the present study.

The vision for the expanded IMW DEWS combining the former UCRB DEWS and the Four Corners Tribal Lands DEWS is reflected in the IMW DEWS 2017-2018 Strategic Plan, developed in late 2016 and early 2017 (NIDIS 2017). The research described in this report, which focuses on the portion of the UCRB in Colorado (Section 2.1), builds on previous efforts to evaluate the UCRB DEWS (for example, McNie, 2014) and was designed to provide insights to support the implementation of the expanded IMW DEWS.

\subsection{Drought in the Upper Colorado River Basin}

As drought is defined as deviation from baseline or "normal" conditions, an understanding of drought in any given location requires first understanding baseline climate and precipitation patterns. Colorado is an arid state, averaging 17 inches of precipitation annually statewide with significant variation across the state (McKee and others, 2000). The dry San Luis Valley averages 7 inches annually while certain high elevation locations in the mountains receive as many as 50 inches annually. All of the surface water in Colorado comes from precipitation, as there are no rivers that flow into the state. At the same time, the state is a headwater source for several major river basins. While precipitation in many parts of the world shows strong seasonal patterns, Colorado is distinct for the spatially complex seasonality of precipitation between locations geographically close together.

This study focused on the Western Slope of Colorado (see Section 2.1), which is the portion of the state located west of the Continental Divide and within the Upper Colorado River Basin. Water that falls east of the Continental Divide eventually flows into the Atlantic Ocean while water that falls west of it flows down the Colorado River and eventually to the Pacific Ocean.

Figure 2 shows average annual precipitation by state water division for the Western Slope. 
The Western Slope (fig. 2) is the source of 70 percent of the surface water in the state (State of Colorado, 2016). However, much of this water is allocated for use outside the area, either downstream to other states through the Colorado River Compact or through transmountain diversions to meet needs east of the Continental Divide, where both municipal and agricultural demands are more intense. This results in two kinds of drought exposure for the water users who live on the Western Slope: direct exposure to diminished precipitation and indirect exposure due to drought outside the region that produces greater demands for Western Slope water. At the same time, the impacts of drought on the Western Slope may extend geographically far beyond western Colorado, given the water supply linkages to eastern Colorado and downstream states.

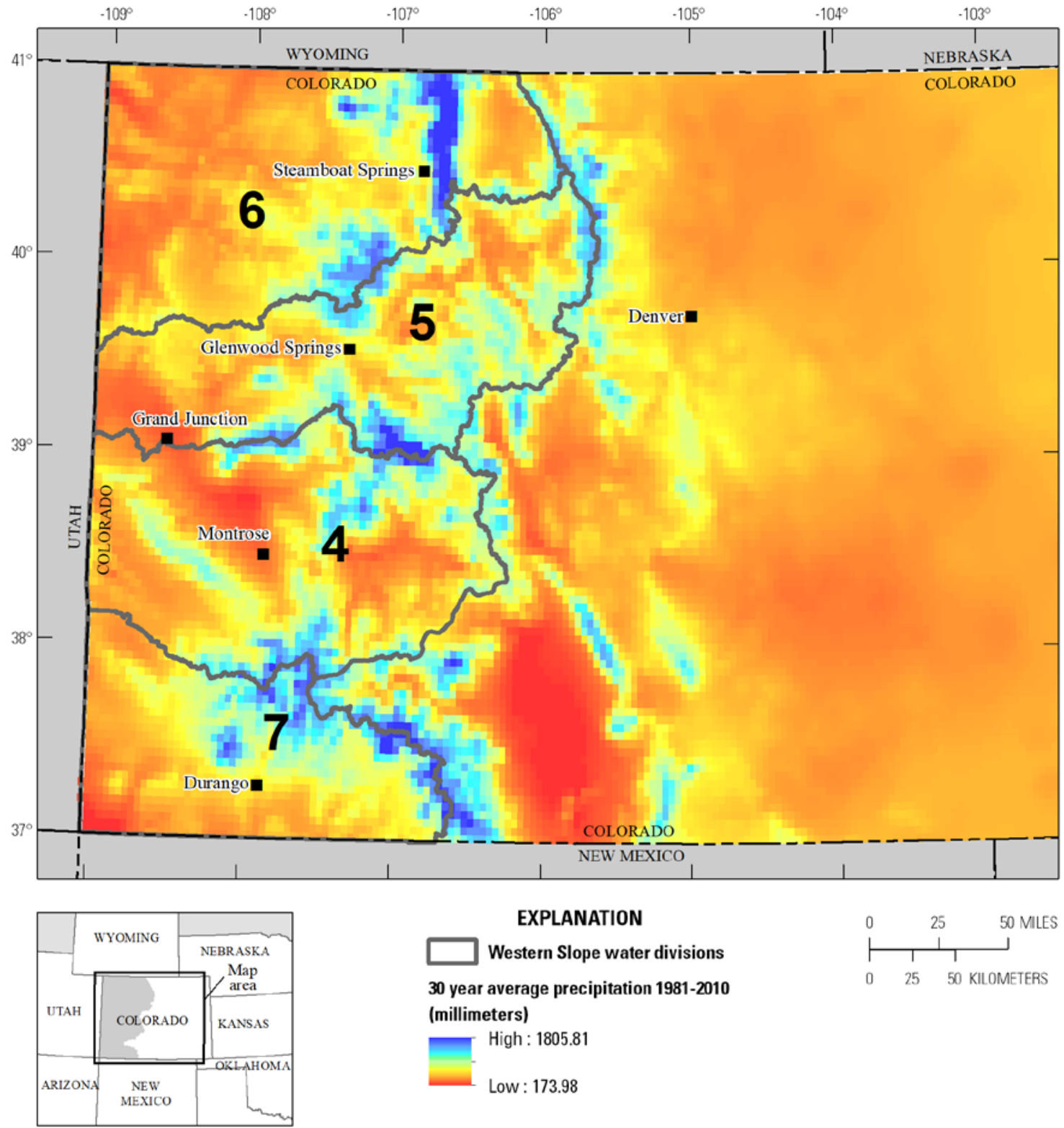

Figure 2. Annual precipitation in the Colorado portion of the Upper Colorado River Basin. The map depicts the four Colorado water divisions located west of the Continental Divide, an area termed the Western Slope. Water Divisions are used by the Colorado Division of Water Resources (DWR) for water right administration and management. (By Wilson Sinclair and Tammy Fancher, USGS) 
Besides the geographical extent of water demands, Western Slope precipitation is used to meet a range of water demands across the agricultural, municipal, recreational, environmental, and energy sectors; drought conditions in the region can have a correspondingly wide range of impacts (McKee and others, 2000; Ryan and Doeskan, 2013; Colorado Water Conservation Board, 2013; McNeeley, 2014). Agriculture remains the primary water demand in Colorado, using 89 percent of the water consumed in the state (State of Colorado, 2015, section 5-3). The major cities in Colorado are east of the Divide; Western Slope water contributes to municipal supplies for many of them. Recreational uses of water include ski resorts (both snowpack for skiing and water for early season snowmaking), whitewater rafting or kayaking, and boating or fishing on lakes and reservoirs. Land management agencies rely on water for maintaining species and habitats as well as supplying buildings and other infrastructure on these public lands. Increased wildfire risk due to drought is also a significant concern. Colorado water is also used for hydropower generation, which can be impacted by low reservoir levels or streamflow during drought.

Droughts have been a frequent and regular occurrence in Colorado over the period for which reliable weather and climate data is available (McKee, Doesken and Kleist, 1999). Figure 3 depicts the fraction of the state in drought based on a 48-month Standard Precipitation Index (SPI) analysis since 1890. Past droughts have shaped current management experiences and response strategies (McNeeley, Beeton, and Ojima, 2016); for instance, the short but intense droughts of 1976-1977 and 1980-1981 led to the initial Drought Response Plan for Colorado in 1981 (McKee and others, 2000). This initial plan was subsequently revised in 1986, 1990, 2001, 2007, 2010, and 2013 (Colorado Water Conservation Board, 2013).

Fraction of Colorado in multi-year drought, based on the 48-month SPI

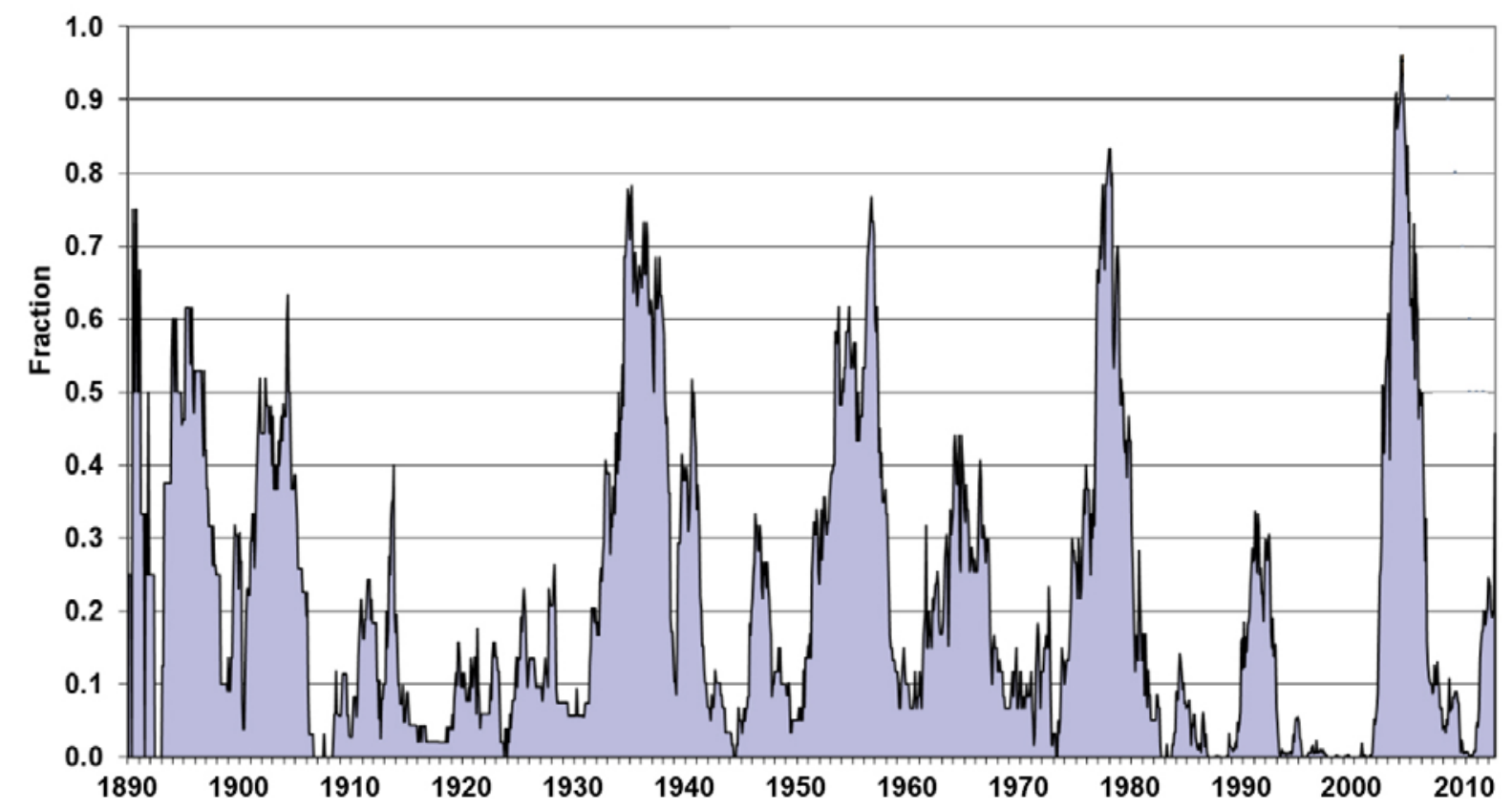

Figure 3. Fraction of Colorado in multiyear drought, based on the 48-month Standardized Precipitation Index (SPI), 1890-2012. (Figure courtesy of the Colorado Climate Center and is not to U.S. Geological Survey publishing standards.)

Increasingly, however, the States and agencies that manage the Colorado River Basin have recognized the uncertainty of future water supply and the potential for more frequent or more severe droughts in the future. The "Colorado River Basin Water Supply and Demand Study" used a scenario planning approach to analyze future supply in the Basin under a range of assumptions about future climate conditions. The study ultimately concluded that "the Colorado River Basin faces a range of potential future imbalances between supply and demand" (Reclamation, 2012, p. 26) caused both by potential changes in supply due to changing weather and precipitation patterns as well as growth in demand. A synthesis of climate science and trends produced by Western Water Assessment (WWA) for the Colorado Water Conservation Board summarized the impact of future climate variability on state water resources:

"In the past 30 years, Colorado's climate has become substantially warmer. The recent warming trend in Colorado is in step with regional and global warming that has been linked to increasing atmospheric concentrations of greenhouse gases. Annual precipitation, which has high natural variability, has not seen a statewide trend over that period. However, some drought indicators have worsened due to the warmer temperatures. As greenhouse gases and other human 
effects on the climate continue to increase, Colorado is expected to warm even more by the mid-21st century, pushing temperatures outside of the range of the past century. The outlook for future precipitation in Colorado is less clear; overall increases or decreases are possible. The risk of decreasing precipitation appears to be higher for the southern parts of the state. The future warming is projected to generally reduce Colorado's spring snowpack, cause earlier snowmelt and runoff, and increase the water use by crops, landscaping, and natural vegetation. While future increases in annual natural streamflow are possible, the body of published research indicates a greater risk of decreasing streamflow, particularly in the southern half of the state*** Most climate projections indicate that heat waves, droughts and wildfires will increase in frequency and severity in Colorado by the mid-21st century due to the projected warming. (Lukas and others, 2014, p. 1-4)"

In the face of potentially greater imbalances between supply and demand in a changing climate, the exposure and sensitivity of the Western Slope to drought also has the potential to become correspondingly greater, making the need for drought early warning information and networks even more significant.

\subsection{Research Objectives}

The UCRB was one of first pilot areas, beginning in 2009, for implementation of a regional NIDIS DEWS. The selection of the UCRB for an initial DEWS reflects the regional importance of drought information for managing water supply for agriculture and other uses, and the need for effective decision support related to drought. Additionally, new drought information products were developed specifically for the UCRB DEWS, and a number of others have been created since 2009, adding to the preexisting toolkit for drought decision making.

The various elements of the UCRB DEWS can be expected to be more or less suitable for different needs of decision makers. As a result, the UCRB makes an ideal case study to examine the use of scientific information products and tools in which the broad decision context (managing drought) is defined, but information needs of current and prospective users vary. Thus decision makers will make varied choices about which of the available tools to use or not use, depending on the particular management and institutional context in which they work. This research aimed to understand the factors that influence the choices of decision makers about whether and how to use particular information sources, products, and tools. The following research questions were investigated:

- What decisions do managers make related to drought in the Upper Colorado region and particularly on the Western Slope of Colorado? About which impacts of drought are they most concerned?

- What indicators and information products do decision makers rely on to manage for the impacts of drought in this region?

- How do decision makers find out about and choose between available drought information sources, products, and tools?

- What gaps (if any) do they perceive in currently available drought information and tools?

Two additional elements of the project which are reported separately (in forthcoming products) explored (1) how scientists producing decision support tools currently interface with decision makers, including how their outreach efforts do or do not match the information channels preferred by managers and (2) how tool users and providers understand the purpose of a drought early warning system.

The study intentionally defined information sources, products, and tools broadly. The goal was to document as many sources of information as possible that respondents reported using to assist in preparing for, responding to, or managing the impacts of drought. A range of information products and tools were identified, ranging from monitoring datasets (for example, SNOTEL network), to modeling tools (for example, USGS StreamStats), to web portals or dashboards (for example, Western Water Assessment Intermountain West Climate Dashboard). Other kinds of information sources also appeared in the study, ranging from reliance by managers on other people to use of scientific research to mental models based on experiential knowledge (Section 4).

This study collectively considers these information sources, products, and tools as decision support. Traditionally, decision support has been defined as computerized systems that provide aid to solving unstructured problems (Geoffrion, 1983). However, in its examination of decision support to aid climate change adaptation, the National Research Council pointed out that there is a second, broader way to define decision support:

"Decision support is often narrowly understood as an activity that provides data, tools and other types of information products that make scientific information more accessible to decision makers***Yet there is a broader view of decision support which is increasingly being adopted $* * *$ In this view, decision support consists of a set of processes intended to create the conditions for the production of decision-relevant information and for its appropriate use. 
Ongoing communication between the producers and users of information is at the center of these processes, and information products are one result but not the exclusive one ${ }^{* * *}$ We adopt this broader understanding of decision support to include both products and processes [National Research Council, 2009, p. 34]."

Given the convening and facilitating mandate of NIDIS, this broader view of decision support as both products and processes makes sense when examining drought early warning systems. Thus, following the NRC definition, when the rest of the report discusses "decision support," it means the diverse class of decision support objects and processes used to make drought decisions in the UCRB. The research investigated how and why information sources and tools for understanding weather, climate, precipitation, and drought impacts are used by managers on the Western Slope of Colorado.

In order to meet this objective, the author necessarily used a broad sampling design (Section 2.2). Most previous studies of decision support tools and processes (for example, Beall King and Thornton, 2016; Cravens, 2016; Morisette and others, 2017) concentrate on the known users or audience of a given tool or process. Such an approach can yield useful information; it gives rich insight into the experiences of users and can suggest design modifications to make existing decision support work better. Yet, it is not an effective approach to capture the perspectives and needs of prospective users or to investigate the factors that influence whether or not someone chooses to use tools in the first place. Essentially, sampling based on known tool users or process participants is a case of sampling on the dependent variable (tool use) (Geddes, 1990). In the case of the UCRB DEWS, the known tool users represent known participants in the DEWS network, but the challenge was how to identify those who might benefit who were not currently participating. To overcome this challenge, this project instead used a geographically based sampling strategy (Section 2.2) in which a range of natural resource managers from preidentified Federal management units and selected State agencies on the Western Slope were considered prospective users of tools and prospective participants in the DEWS network. The prospective users were then asked to describe in an open-ended way what information and tools they do or do not use and why. This approach allowed for respondents to report both use and nonuse of tools and thus the ability to identify factors that influence information and tool use choices of managers.

\section{Methods}

This study relies primarily on qualitative data collected using open ended, ethnographic discussions with one (or occasionally more than one) respondent. This qualitative approach was supplemented by review of relevant literature and attendance as a participant-observer during the Colorado Climate Center UCRB and IMW DEWS regular update webinars during the study period (May 2016 to July 2017).

A qualitative, ethnographic approach was chosen for two reasons. First, it allowed for nuanced exploration of user experience with decision support in the region and enabled the discovery of unanticipated factors influencing choices to use or not use tools. For instance, one Bureau of Land Management (BLM) manager reported that she considers herself part of the "Southern Rockies" but does not really think of herself as part of the "Upper Colorado River" region, given her terrestrial focus. This kind of comment about perceptions is subtle and unlikely to emerge through a survey approach. Second, McNie (2014) completed a NIDIS-funded survey of UCRB users (supplemented by a limited set of interviews) that provided information about whether or not specific types of drought information were being used and whether or not that information was considered useful or credible. Using qualitative methods in this study thus provided an opportunity to consider what had changed in the past three years as well as gain greater insight into experiences of users and prospective users. The qualitative format is ideally suited to this task due to the focus on understanding the experiences of subjects (Crabtree and Miller, 1999).

The following subsections provide greater detail about the research design and methods. Section 2.1 describes the study area, Section 2.2 describes the sampling strategy, Section 2.3 describes the data collection, and Section 2.4 describes the data analysis.

\subsection{Study Area}

As described in Section 1, the UCRB was one of the first pilot areas, beginning in 2009, for implementation of a regional DEWS under NIDIS. Thus the core study area was defined to focus on the Upper Colorado River Basin. Specifically, the research focused on Colorado Water Divisions 4, 5, and 7 (fig. 4). This area represents the portion of the Upper Colorado River Basin within Colorado minus the Yampa-White River Basin (Colorado Water Division 6). The Yampa-White River Basin was excluded from the study area as the Department of the Interior (DOI) North Central Climate Adaptation Science Center (NCCASC; formerly North Central Climate Science Center), one of the sponsors of the research, had recently funded another project in the Yampa-White River Basin focusing on Federal and State managers with responsibility for drought (North Central Climate Science Center, 2015). The author and project sponsors felt there was a high potential for stakeholder fatigue if this research also targeted that same pool of participants. 


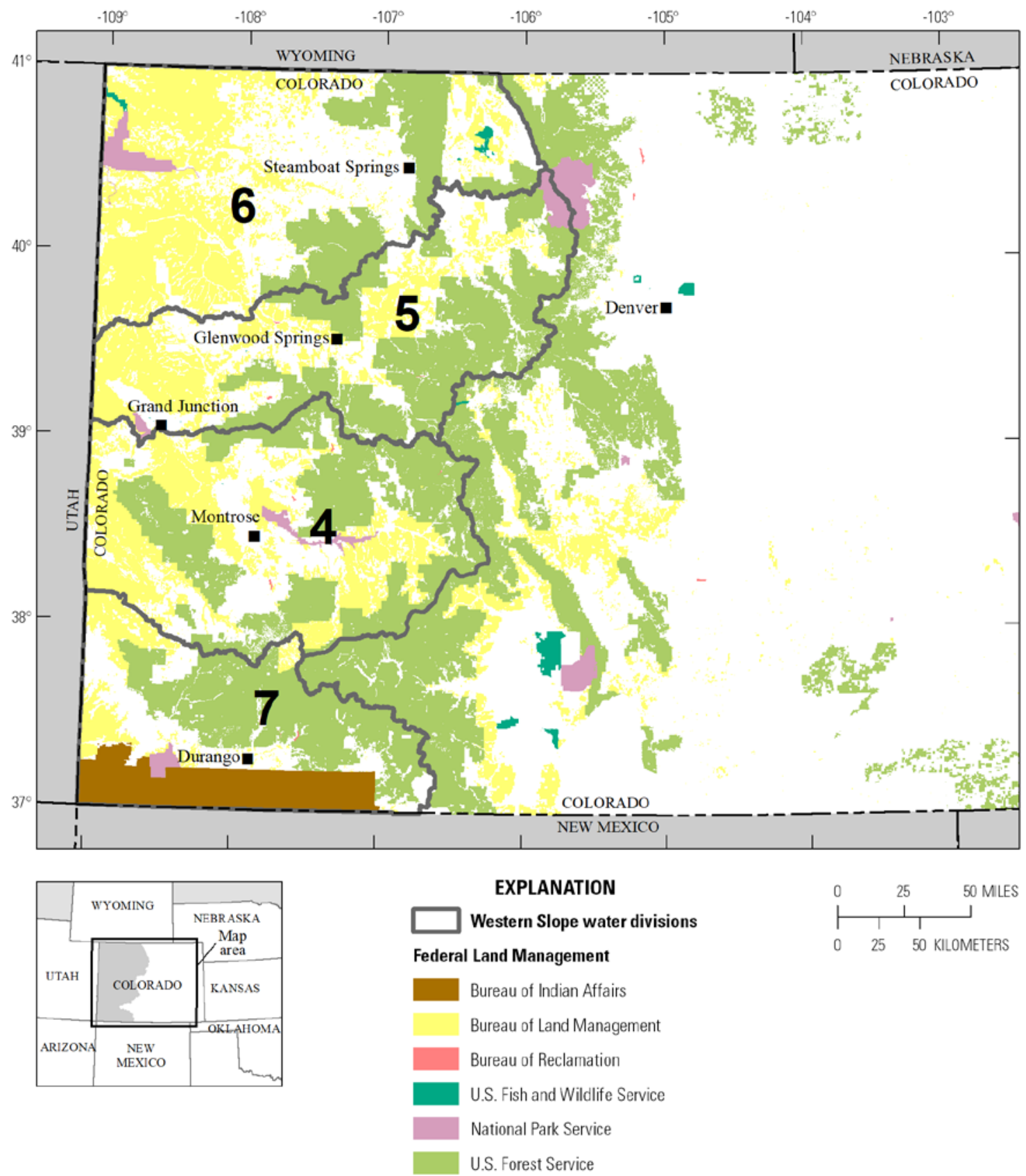

Figure 4. Colorado Water Divisions and Federal land management units on the Colorado Western Slope, used as the sampling frame for the study. (By Wilson Sinclair and Tammy Fancher, USGS). 


\subsection{Study Sample}

A main objective of the research was to investigate the experience of both known tool users and prospective tool users, as described in Section 1.3. To meet this objective, the study used a broad geographically-based sampling strategy in which a range of natural resource managers from preidentified Federal management units and selected State agencies on the Western Slope (fig. 4) were assumed to be prospective users of drought information and then asked to describe what information and tools they do or do not use and why. This approach thus avoided the challenge of identifying current users of tools and allowed investigation into to why or why not someone chooses to use the information source(s) they use.

Within the three Colorado Water Divisions defined as the study area, the sampling strategy sought to identify as many prospective tool users as possible. This was done in the following ways.

- Federal management units: Each Federal land management unit within the study area (fig. 4) was identified using The National Map of the United States (Dollison, 2010). A combination of conversations with the contacts of the author in agency headquarters offices and web searching was used to identify individuals in relevant positions within each of these management units. Depending on the unit, the identified individual might be either an appropriate technical specialist (for example, Hydrologist, Rangeland Management Specialist) and (or) an administrator (for example, Resource Management Chief, Field Office Manager). In some cases, an invitation originally sent to an administrator was delegated to a technical specialist; the invitation language encouraged recipients to suggest someone else if they felt they were not the right person to participate.

- Water conservancies and conservation districts: Each water conservancy and conservation district within the study area was identified using the Colorado Water Congress list of Water Conservancy and Conservation Districts (Colorado Water Congress, 2017). A contact for each conservancy and conservation district was identified using either web searching, phone calls to listed contact information, or the Bureau of Reclamation Roster of Water User Organizations (Reclamation, 2015).

- Relevant State agencies were identified through consultation with NIDIS and the Colorado Climate Center. Of the State agencies with land and water management responsibilities that might be impacted by drought, only the Colorado Division of Water Resources was included in the final study sample. Other State agencies whose scope was deemed less relevant the research objectives (for example, Colorado State Forest Service, which manages primarily private lands) were excluded.

- Snowball sampling: Respondents were asked to identify potential additional respondents. While the study was not a true snowball sample in which conversations were conducted until saturation was reached (Morgan, 2008), these suggestions were used to ensure no significant gaps existed. For instance, many technical specialists employed by the U.S. Forest Service discussed the importance of their interactions with the fire management staff in their offices. As a result, fire managers from each Colorado Water Division in the study region were added to the sample.

Despite the attempt to develop as comprehensive a sample of information users as possible, two factors influenced the group of participants in the final sample. First, given the geographical size of the study area, the scope of the study had to be limited to Federal agencies, water conservancies, and State water agencies. These agencies were deemed the most relevant to drought management, but many other State agencies and county or municipal level agencies could have been included. Second, while invitations were sent broadly, there is the possibility of selection bias influencing who chose to respond affirmatively to the invitations; it is possible that those who play a peripheral role in drought management might have been less likely to respond. Respondents included in the study represent a range of job titles, however, as do those who declined to participate or who did not respond to the invitation to participate. Additionally, individuals within an agency often use information in diverse ways depending on their location; this study design was not able to capture all these nuances of geography.

\subsection{Qualitative Data Collection}

Sixty-one prospective users were invited to participate in the study. Thirty-one of these ultimately agreed to participate. Of the 30 individuals who did not participate, 8 declined participation (5, because they were too busy and 3 , because they did not feel their job role was relevant to the study aims), 17 did not respond after 3 email invitations, and 5 responded with interest but did not schedule a discussion before the end of the study period. While the response rate might seem low, the intentionally broad nature of the sampling strategy made it likely that individuals would be contacted whose actual job roles were not relevant to the study design or who did not see the relevance of the project to their work. 
Discussions were primarily conducted over the phone from September 2016 to February 2017, though six conversations with respondents in the San Juan Basin and on the Front Range were held in person. All conversations were conducted by the study author. The majority were one-on-one conversations, though a few included additional staff from the same organization.

Prior to the conversations, participants were provided with information about the study by email and asked if they agreed to participate. At the beginning of each conversation, permission was requested to audio record. In all cases, permission was granted. All conversations were later fully transcribed to prepare for coding.

Thirty-one ethnographic conversations were carried out for this study with 33 individuals (due to additional staff joining a few conversations). Based on their agency and job title, respondent conversations were classified as land (13), water (9), fire (5), wildlife (1), or other (3) managers as well as Federal (22), State (2), or local (7). (Note these totals count conversations with more than individual from the same organization as one conversation; the same convention is used in the remainder of the report.) Participants were also classified according to the Colorado Water Division in which the majority of their work takes place, though the mismatch between Colorado Water Division and land management boundaries makes this a sometimes imperfect classification. The distribution of participant conversations between the three Colorado Water Divisions in the study area was as follows: Division 4 (10), Division 5 (4), Division 7 (8), multiple water divisions (5), and Eastern Slope managers who rely on Western Slope water (4).

Discussions were open ended and were guided by the following key topics of interest linked to the study objectives: (1) respondent role in drought management and drought impacts of interest; (2) indicators, information, and tools the respondent and their organization makes use of to understand and assess drought impacts of interest; (3) the means by which participants find out about new tools or developments in drought management or science; and (4) gaps respondents perceive in drought information (if any).

\subsection{Qualitative Data Analysis}

Audio recordings of the ethnographic conversations were transcribed by a professional transcription service. Transcripts of all conversations were coded by the author using NVIVO 10 Pro software. Two complementary coding methods were used. First, a preliminary thematic coding scheme was developed based on the study objectives and literature review (Guest, MacQueen, and Namey, 2011). Key themes in the preliminary analysis included: (a) management contexts, (b) drought impacts, (c) information sources, (d) drought indicators, (e) finding out about new tools, (f) usability criteria, and (g) gaps in drought information.

Each conversation was coded using this scheme. In order to account for findings not anticipated by the original research questions, a series of emergent codes were also developed following the principles of grounded theory (Corbin and Strauss, 2008). After preliminary coding of each transcript was complete, the resulting codes were consolidated to eliminate analogous or duplicate concepts and to reorganize similar ideas into overarching themes. The results of this consolidation is reflected in the final codebook included in appendix 1.

The consolidated themes and coding scheme were also used as the basis to create a typology of users. A table was created noting the presence or absence of the main themes for each conversation. This analysis grid was used to identify common characteristics between respondents and thus classify the respondents into five "user profiles," described in Section 3.3. (A refined version of the table used for the user profile analysis appears as table 3 in Section 3.2.)

User profiles or personas are a technique used by software developers to understand a typical user within a target audience for a product (U.S. Department of Health and Human Service, n.d.). A description of a user profile is not meant to be a description of an actual individual, but rather to capture salient characteristics of a pool of users; a collection of three to five profiles might then capture the major differences in audience use for a given tool. In this case, the five inductively-generated user profiles described in Section 3.3 capture important differences between groups of respondents in the study. Broadly, the five groups differ in the types of drought impacts and indicators in which they are interested, which then impact the information they use and where and how they find out about drought tools, though there are certain impacts and indicators that are relevant to multiple of the five "types" of drought information users. This technique of generating user profiles from ethnographic or interview data can be thought of as a qualitative analysis analogous in concept to cluster analysis in statistical analysis, although the groupings reported in table 3 and summarized in Section 3.3 should not be treated as statistical data.

The presentation of results in this report generally follows the consolidated coding scheme. Within each section, nuances and variation between users are described. 


\section{Managing for Drought in the Upper Colorado River Basin}

Section 3 addresses the question of who manages for drought in the UCRB. It investigates the decisions that respondents make (or support others in making) in the study region and explores which particular impacts of drought they are most concerned about. The intentionally broad sampling strategy of the study resulted in conversations with an array of State and Federal managers, who work under a variety of regulatory frameworks and manage a variety of natural resources (Section 3.1). As a result, they are concerned about a wide range of drought impacts and use a corresponding wide range of indicators to understand the status of their resources of concern (Section 3.2).

\subsection{Resource Management Decisions Impacted by Drought in the UCRB}

Respondents described a wide range of decisions impacted by drought in the study region. The main decision contexts are described in Sections 3.1.1 to 3.1.7, along with relevant variations in which participants were most concerned about those impacts. Participants also described the time scales of their decisions, which range from daily choices through long term planning aimed 10 or more years into the future.

\subsubsection{Water Supply Operations}

Perhaps the quintessential drought decision is managing water supply for irrigation and municipal supply. Given the snowmelt-driven nature of the study region (Section 1.2), water supply operations decisions happen on an annual cycle that begins with the spring runoff season. Respondents responsible for water operations-who included staff of conservancies or conservation districts and Reclamation - described two general varieties of operations decisions, depending on the amount of reservoir storage available in a given system. Systems with significant storage capacity rely on carryover storage levels in late winter or early spring as a key indicator; operators of these systems aim to keep as much new runoff in the system as possible while not exceeding storage capacity. They then release water throughout the drier summer months as needed to meet user demand. Operators with less storage capacity, on the other hand, follow a simpler "fill and spill" strategy as they have no way to store additional runoff even in above-average flow years. As a result, demand by their water users tends to exhaust supply each year, and thus they rarely have the ability to maintain any amount of water between water years. ${ }^{1}$ Both types of operators rely heavily on winter and spring snowfall levels, estimates of snow-water equivalent (SWE) in the snowpack, and forecasts of runoff peak and timing to understand the projected and actual amount of water available.

For both kinds of operators, the needs of other water users must be balanced against the demands of their primary irrigation or municipal users, though the exact rules governing the balance vary depending on the particular water project being managed and the nature of the water rights they hold. Instream flow rights or the presence of endangered fish species may require releases at certain times or in certain volumes to ensure species protection goals; high-volume peak flow releases are especially important to the endangered native species that are the targets of the Upper Colorado River Endangered Fish Recovery Program (Public Law 106-392). When possible or sometimes when required by Federal Energy Regulatory Commission (FERC) operating licenses, operators may try to time releases at levels and times (for example, Memorial Day weekend) that are useful to the recreational boating and fishing community or may try to manage reservoir levels for marina operations. Other water projects with hydropower generation capacity may have rules or norms about timing water release to optimize power generation. In the case of Reclamation dams, the power generated by releases is marketed by the Western Area Power Administration (WAPA; part of the Department of Energy). Though the specifics vary by Reclamation project, the Reclamation and WAPA generally coordinate release schedules to meet power generation goals, although Reclamation retains formal authority to determine releases.

\subsubsection{Ecological Health and Resiliency}

Four of the thirteen respondents who work for land management agencies (including the National Park Service [NPS], U.S. Forest Service [USFS], and the U.S. Fish and Wildlife Service [USFWS]) described drought-related decision making focused on maintaining overall ecological health and resilience. Rangeland management decisions made by a second set of respondents from USFS, BLM, and Natural Resources Conservation Service (NRCS) are described in section 3.1.3; the key difference between these two groups is the time scales on which they make decisions. Five more land management respondents also described impacts that drought can have on ecosystems, though they classified their own responsibilities as outside the definition of "managing for drought" (Section 3.1.7).

\footnotetext{
${ }^{1}$ A water year is "the 12-month period October 1, for any given year through September 30, of the following year. The water year is designated by the calendar year in which it ends and which includes 9 of the 12 months. Thus, the year ending September 30, 1999 is called the "1999" water year." See https://water.usgs.gov/nwc/explain_data.html.
} 
An NPS administrator summarized his understanding of drought: "at the highest, very broad programmatic level, drought would directly affect ecosystem resiliency, for which we're definitely responsible. Of course, there is cascading effects, either for rare, sensitive species, or rare, sensitive ecosystems like riparian areas, and then the species that depend on all of those things." Respondents described a range of plant and animal species, habitats, and ecological processes that can be affected by drought in the areas they manage. One NPS administrator pointed out that a recent assessment in her park identified "over 100 resources" that could be harmed by the future arid climatic conditions expected in her area. These respondents tended to take a longer-term view of drought, as their work often involved decisions about multiyear restoration projects, National Environmental Policy Act (NEPA) analysis for longer-term projects, or longer-term resource planning (Section 3.1.5). Another NPS administrator pointed out that "wintertime drought" (that is, lack of snow) can harm species like pika (Ochotona princeps) as much as lack of summer water, in contrast to other types of managers who may focus primarily on spring and summer water availability. Some of these ecologically-focused participants heard "climate change" when asked about drought; others explicitly clarified that year-to-year fluctuations in water availability or temperature do not matter so much as long-term trends. A USFS technical specialist, for instance, stated,

"I think that as land managers, we're a little less sensitive to drought and probably a little less tied to the immediate impacts of drought compared to, for instance, the water management agencies. That's their life. They're so intimately connected to the water supply that having very up-to-date information on drought is very important. I think that the work that we do is less sensitive to drought. It just becomes another part of the cycle. I think that we probably spend as much time thinking about climate change, about long term changes to temperature and precipitation pattern as we do to drought."

Additionally, a few respondents suggested that data about how year-to-year fluctuations in water and temperature affect ecosystem health can be scarce and that as a result their units have focused less on year-to-year impacts (Section 6).

Respondents were concerned about the effect of drought on ecological processes. Drought can make fires more frequent or severe, lead to changes in invasive species populations like cheat grass, change conditions to make native species unable to successfully compete, degrade water quality, dry up seeps and springs, and speed up geological processes like erosion. A more unexpected example was mentioned by a technical specialist at Black Canyon of the Gunnison National Park, who described how lower water levels during drought prevent scouring of the canyon bottom, leading to undesirable vegetation growth.

Participants discussed how drought and associated consequences (including changes to the fire regime and invasive species populations) can impact a range of terrestrial and aquatic flora and fauna. Changes to fire patterns can affect certain species more than others; the old growth piñon-juniper forests in the San Juan Basin were mentioned as an example of a vulnerable system. An NPS technical specialist described the vulnerability of plants and animals that depend on groundwater-fed seeps and springs. Scarce water may limit water available for fish, or influence release schedules that privilege the needs of irrigation over fish biology, although the presence of endangered fish species in much of the basin has led to operating agreements on many river sections that coordinate releases between water operators and State and Federal partners through the Upper Colorado River Endangered Fish Recovery Program. In other areas, however, water rights predate the land management units; one USFS technical specialist in Colorado Water Division 7 described how drought can leave fisheries vulnerable if streams are dewatered to fulfill other water obligations.

These respondents relied on a range of indicators to manage for ecological health, but notably relied on local scale monitoring and experiential knowledge of the systems in which they work to a greater degree than those making other types of decisions. This may reflect the relative scarcity of available ecological indicators. The impacts of drought on ecosystems are relatively poorly understood, compared to impacts of drought on agriculture or water supply (Crausbay and others, 2017), but these responses of the land managers emphasize the many ways drought can influence individual species, ecological processes, and the overall health of an ecosystem.

\subsubsection{Rangeland Management}

For another set of land managers (BLM, USFS, and the one NRCS participant) within the sample, drought is salient on shorter time scales within a water year. These were respondents in rangeland management and related roles (for example, Hydrologist or Ecologist), tasked with making decisions about if and when to curtail permittee grazing in response to drought conditions and where and how to manage weeds. They described the need to balance fulfillment of user expectations with maintaining the "long-term ecological health" of vegetation and the overall system. A BLM administrator described how annual decision making interacts with long term management goals:

"A lot of the time, in the permittees' eyes, it's a year-to-year thing. Now, in our eyes, it is something we [also] look at long-term. Basically, we try and look at it - if we're seeing these conditions over so many years, say five years or three years, then we know we have to make some pretty drastic changes out on the landscape. Otherwise, we're going to lose some of the plants*** species composition will change and that type of thing." 
These six participants focused on vegetation health and productivity as their primary indicators of concern. They also monitored indicators that influence vegetation condition, including temperature, spring runoff, snow-water equivalent (SWE), summer streamflow, monsoon timing, and soil moisture. Similar to managers concerned with other aspects of ecological health, these respondents relied heavily on local monitoring and experiential knowledge or observation to gage vegetation condition, forage quality, and soil moisture.

Two respondents reported using formal threshold levels that are defined in a drought plan to assess when drought conditions are severe enough to restrict permittee grazing. Other respondents rely on a combination of indicators to make that decision but did not use a formal drought plan or threshold level. The U.S. Drought Monitor was mentioned as particularly important, though it serves less to inform managers to understand the conditions than to communicate and justify decisions to permittees (Section 4.1).

\subsubsection{Fire Management}

Fire management decisions were made primarily by fire managers (for example, Fuel Specialist, Fire and Aviation Staff Officer; Fire Management Planning and Analysis staff for a national forest or zones within it), though nonfire technical specialists (for example, Rangeland Management Specialist) and administrators also mentioned how drought impacts fire ignition risk and prescribed burns. Fire management decisions affected by drought as described by respondents fall into three main categories: managing prescribed burns and fuel loads, understanding and managing wildfire risk, and suppressing wildfires that do start. Drought conditions affect each of these decision categories, but on different time scales.

Prescribed burns are the primary tool available to manage fuel loads with high potential to create dangerous wildfires, though mechanical thinning or tree removal methods may also be used (for example, along a road). Respondents described how a prescribed burn plan sets thresholds for key indicators like relative humidity, air temperature, and wind speed; if conditions exceed these thresholds, the burn will not take place as there is considered to be too high a likelihood of losing control of the fire. Most prescribed burning takes place in cooler, wetter months, avoiding the warm, dry and often dangerous summer conditions.

Two fire-specific indicators that are used to predict the behavior of prescribed burns as well as wildfires are dead fuel moisture and the Keetch-Byram Drought Index. Both of these indicators capture how hot and dry conditions in the recent past have affected moisture levels in the soil and (or) vegetation. The dead fuel moisture measures "the amount of water in a fuel (vegetation) available to a fire, and is expressed as a percent of the dry weight of that specific fuel" (NOAA, n.d.) While dead fuel moisture measurements are available for a range of fuel classifications, the fire managers in this study emphasized the 1,000-hour fuel measurement (for example, the amount of moisture in 3- to 8-inch thick fuels) as most relevant to the Western Slope terrain. Respondents also emphasized the importance of the Keetch-Byram index, which measures fire potential. The index is expressed as the amount of precipitation necessary to return the soil to full field capacity; field capacity refers to soil water content when soil is wet and holding water against gravity (World Meteorological Organization (WMO) and Global Water Partnership (GWP), 2016; Lopez and Barclay, 2017).

Respondents described making use of the same suite of indicators to continually and iteratively monitor and assess wildfire risk, and thus make decisions about allocating equipment and staff as well as communicate that risk to the public and-if severe enough - implement bans on fires, close roads (for example, in a national forest), or otherwise seek to minimize the risk of human ignition. They emphasized that drought does not directly cause wildfires (since any given fire needs an ignition source), but that drought significantly increases fire risk by drying out fuels brought on by hot, dry weather. Fire risk exists at both a seasonal and an extremely short-term timescale. On the one hand, fire managers described making use of seasonal projections and aggregated snow and precipitation data to understand general trends for what a fire season might look like. On the other hand, they described how the fire risk can change in a few days if a large rainfall soaks vegetation; indicators used during fire season focus on understanding the impact of dry fuels and warm or dry air. This subseasonal perspective gives fire managers a uniquely short-term perspective on drought, as one USFS technical specialist pointed out: "Well, two weeks of drying will quickly put us in a fire situation or fire risk along the lower foothills of Colorado and east of the divide. Within a couple weeks, we could easily see large fires, given an unseasonably warm and dry condition." The sometimes fast-changing fuel-to-moisture ratio is a key indicator for fire managers.

When a fire does start, the same short-term indicators are used on a daily or more frequent basis to monitor changing fire risk that can impact public and firefighter safety. Changes in weather drive changes in the behavior of a fire, which can increase its size or severity, send it in the direction of valuable resources, or increase the danger to firefighters. Drought conditions also influence the risk of other fires starting, which can influence decisions about sending crews out of their local district to help on other fires. 


\subsubsection{Planning}

Participants reported that drought is a consideration in long-term water supply, drought preparedness, land management (e.g., National Forest or National Park), NEPA assessments, land use, and climate adaptation planning. Longer-term decisions about infrastructure or project investments rely on understanding of current year-to-year trends as well as future projections for climate and precipitation. Six technical specialists from BLM, USFS, NPS, and USFWS described how their various levels of planning processes seek to identify resources vulnerable to drought and develop high-level strategies to respond. Once in place, those strategies then guide the development of specific projects.

Four of these respondents and three who had not mentioned planning earlier specifically discussed their concern about droughts of the future in a changing climate and efforts to respond or adapt; they were concerned about effects of climate change that include but extend beyond those of drought. For instance, an NPS administrator mentioned how climate projections suggest the park will receive more frequent heavy precipitation events in the future, which might lead to harmful erosion. A county government employee discussed how land use planning work is minimally affected by short-term drought as the county does not manage water resources directly but is very concerned about long-term climate variability. Two respondents so strongly equated drought and climate change that they heard questions about drought impacts as questions about climate change; they focused all their responses on long-term climate variability and did not mention the cyclical, shorter-term drought challenges described by other participants.

\subsubsection{Other Drought Impacts}

Respondents across agencies and job roles described a range of other contexts in which drought influenced their activities and budgets. These included instances where drought conditions required a deviation from normal operations in terms of infrastructure, personnel management, or visitor management.

Infrastructure can be affected by drought. An employee at Rocky Mountain National Park described how snow conditions determine the road opening date for Trail Ridge Road. A USFS fire manager described how fire risk (Section 3.1.4) can become a public safety issue in small mountain communities with limited roads in and out; prescribed burning or fuel treatment projects may be prioritized by public safety concerns. A USFS technical specialist mentioned a discussion in his forest about culvert sizing in anticipation of greater future climate variability (including both wet and dry periods). An NPS administrator discussed how the park relies on park water rights to supply water for the park, but the park is not the senior water rights holder and thus can find itself facing water supply shortages in drought years.

Respondents described how drought affects staffing decisions, particularly regarding temporary or seasonal staff. Fire managers emphasized that fire suppression and management relies heavily on temporary staff; one USFS fire manager explained, "I'm [constantly] evaluating what our staffing levels should be based on current and future trends in weather. Fire behavior is directly tied to percentile weather conditions, so we're keeping a close eye on that daily and that drives what resources we put where and when, and what we're willing to let go from our forest to go help other units." A state water agency employee reported allocating additional overtime for staff during drought conditions and shifting staff from the office into the field sooner during dry springs than wet ones.

Drought conditions can alter visitor numbers or impact recreation activities available to visitors in some land management units. A BLM administrator described how drought can determine the length and (if severe enough) even the existence of the river recreation season, which determines how many permits her office would issue. Water supply managers also make decisions that influence river recreation; a water operator described how his office works with whitewater boating advocates to publicize releases and release water at boatable levels or on weekends. Sometimes the link goes the other way, with water or snow levels affecting recreational patterns. A county government employee discussed the detrimental effect of snow drought on his community, which relies heavily on ski tourism.

The impacts of drought on natural resources can have secondary effects on visitors and recreation as well. When fuel conditions make fire risk a concern, agencies may have to manage recreational use to decrease the chance of human-caused ignition. A USFS technical specialist explained how drought conditions generally determine when the forest decides to implement fire bans; similarly, a NPS administrator described increasing needs to enforce policies against illegal campfires that have caused costly wildfires. Another NPS administrator described the increased vulnerability of high visitation areas in the park during drought, including seeps, springs, and riparian areas that appeal most to visitors in the arid region but also are ecologically sensitive. 


\subsubsection{Participants Who Do Not Manage for Drought As Such}

As described in Section 2, the respondents in the study were deliberately selected using a broad sampling strategy that sought to identify a range of prospective users of drought information and tools. As a result of this approach, seven respondents described management responsibilities or decision contexts that might on face value seem to be influenced by drought, but were actually described by the respondent as minimally impacted by drought. Participants described three reasons for this.

First, some respondents had water management-related responsibilities that do not significantly change during drought conditions. Two State water agency employees described their role in water rights administration. While their roles might become more challenging during a drought due to increased conflict between water users, their day-to-day responsibilities and decision making do not change if less water is available. During a drought, they simply enforce the rules with whatever water is present in the system. Two WAPA employees described working closely with Reclamation staff who manage water operations at the dams for which WAPA markets the hydropower. Drought conditions may require adjustments in rates or contracts on the power marketing side if there is not sufficient water available to meet long-term contractual operations, but WAPA is not itself responsible for managing water supply in response to drought. A county government employee was responsible for land use planning, but his department had no jurisdiction over water supply. They must work closely with the relevant water supply operators.

Second, managing for drought requires a certain baseline understanding of the resources in a unit and the impact that decreased water availability has on them. One NPS technical specialist discussed his inability to manage for drought due to the lack of baseline data available:

" [We are] just not far enough along that we've even considered implications of drought yet. We are trying to map,

determine the resources we've got, do the testing we want to do. We're just not there yet, as far as engaging in any

kind of drought planning process***We know it's going to be affected by drought, or possibly long-term changes in the climate, but we're just not there yet because we don't know what we have."

The role of the technical specialist at present is focused on monitoring and research to develop the prerequisite understanding of the impact of drought on resources in his management unit. The lack of data in the management unit meant the job looked quite different from other respondents with the same job title in the region.

Third, a subset of land managers from multiple NPS units described how the geographical or institutional context of their management units influence their (lack of) role in relation to drought. While they might recognize ecological impacts of drought in their units, they did not necessarily have control over decisions that would alter these impacts. An NPS administrator explained,

"We don't really have water-based recreation or water-based uses. [Water] availability in a calendar year, any fluctuations in that doesn't really affect anything that we do *** I know that we have [ephemeral] pools that form*** whether they are there or not there's really nothing I do on a management level that is impacted by that or that I can influence."

Two NPS technical specialists described how they manage as best they can, given the constraints of existing water rights and decisions made by Reclamation. Essentially, both described situations where they react to the Reclamation water operations decisions and use information to stay informed about what Reclamation might decide to do, but do not have enough control over water management in their units to feel they were actually "managing for drought" themselves.

\subsection{Drought Indicators and Indices}

In order to make the decisions described in Section 3.1, managers and decision makers rely on a range of indicators. After discussing the decisions they make and how drought impacts those decisions, respondents were asked which drought indicators they consider the most relevant for their management needs. This section details their responses, describing how indicators varied by user profile type.

The definition of "indicator" used here is more inclusive than is typical in the drought monitoring literature. As technically defined in the World Meteorological Organization (WMO) and Global Water Partnership's (GWP) "Handbook of Drought Indicators and Indices," an indicator is a "variable or parameter used to describe drought conditions. Examples include precipitation, temperature, streamflow, groundwater and reservoir levels, soil moisture and snowpack [WMO and GWP 2016, p. 3]." The Handbook of Drought Indicators and Indices also defines two related concepts: an impact is "an observable loss or change at a specific time because of drought" while an index is a "computed numerical representation of drought severity, assessed using climatic or hydrometeorological inputs including [other indicators] [WMO and GWP 2016, p. 3]." In the drought monitoring literature, indicators and indices are both rigorous measures that correlate with drought onset and (or) recovery and enable historical and statistical analysis (Steinemann, Iacobellis, and Cayan 2015; Heim 2002). In this study, the goal was to capture 
how respondents understand indicators. As a result, this section reports everything that participants reported they consider to be an indicator, including measures like "increases in invasive species" that would be more properly classified as a drought impact according to the definitions in the literature. The difference in the expert and respondent definitions reflects (a) the relative paucity of statistically robust indicators for certain kinds of drought impacts, particularly related to ecological drought and (b) possible differences between scientist and manager understandings of what an indicator is.

Given the objectives of the research, indicators are also distinguished from the information products, sources, and tools used by managers (Section 4). While sometimes the name of the dataset or decision support tool used to get information about a given indicator can be used as shorthand to refer to an indicator, technically the indicator is the variable being measured and the information source is where someone is getting values for that variable. For instance, streamflow is an indicator. USGS streamgages are one common information source that provides values for streamflow, but streamflow data may also be available from Tribal or State monitoring programs or can be a component in calculated indices.

Indicators described by respondents were grouped into overarching categories based on the kind of decision they were being used to make. Table 1 provides an aggregate view by category of the drought indicators described by land, water, and fire managers in the study. Table 1 suggests a few observations about drought indicators as understood by study respondents. First, as noted above, many of the entries appearing in table 1 that respondents described as indicators, particularly in the ecological indicators category, do not meet the technical definition of an indicator as understood by the drought monitoring community. Second, indicators have different meanings to different users, and thus the classification of some indicators relied on the context in which users in this study mentioned particular indicators. For instance, wildfire risk at longer time scales was discussed in the context of overall ecosystem health (and thus was categorized as an ecological indicator) while risk of ignition on shorter timescales was a primary concern of fire managers (and thus it was categorized as a fire indicator). Groundwater appears on the list as both an ecological indicator (the context in which it was mentioned by three out of the four respondents who discussed it) and as a water supply indicator (the context in which the fourth respondent mentioned it). Water quality was discussed primarily in the context of ecosystem health and thus is categorized as an ecological indicator, though users managing water supply may also be concerned about water quality. Third, climate change and variability were mentioned as general topics by many respondents, but specific indicators of climate change were not discussed. This is likely the result of the structure of the ethnographic conversations and possibly user uncertainty about how to assess the impact of climate change on the systems they manage (Section 6.2).

Table 2 addresses the link between decision context and indicator. It summarizes the main decisions described by respondents that were described in detail in Section 3.1.1 through 3.1.7, linking them to the key indicators used to make each type of decision. Table 2 suggests that numerous, fairly standardized sets of indicators are used for making water supply and fire management decisions. Indicators for ecosystem health and rangeland management, on the other hand, are less standardized.

Table 3 is organized by respondent, providing a more detailed view of individual experiences by linking decision context and timing with key indicators and information sources that each respondent reported relying on. The information in each of the columns of table 3 is expanded on elsewhere in the report text, as noted in the table footnotes. As described in Section 2.4, table 3 formed the basis for the inductive grouping of users into five types or "profiles" of drought users (Section 3.3) based on decision context, indicator and information use, and information network. 
Table 1. Drought indicators reported by respondents.

[This table presents an aggregated list of indicators described by study respondents organized by general indicator category. Within the sublist for each category, indicators are sorted alphabetically. Indicators marked with ** appear in more than one category because different respondents mentioned it in different contexts]

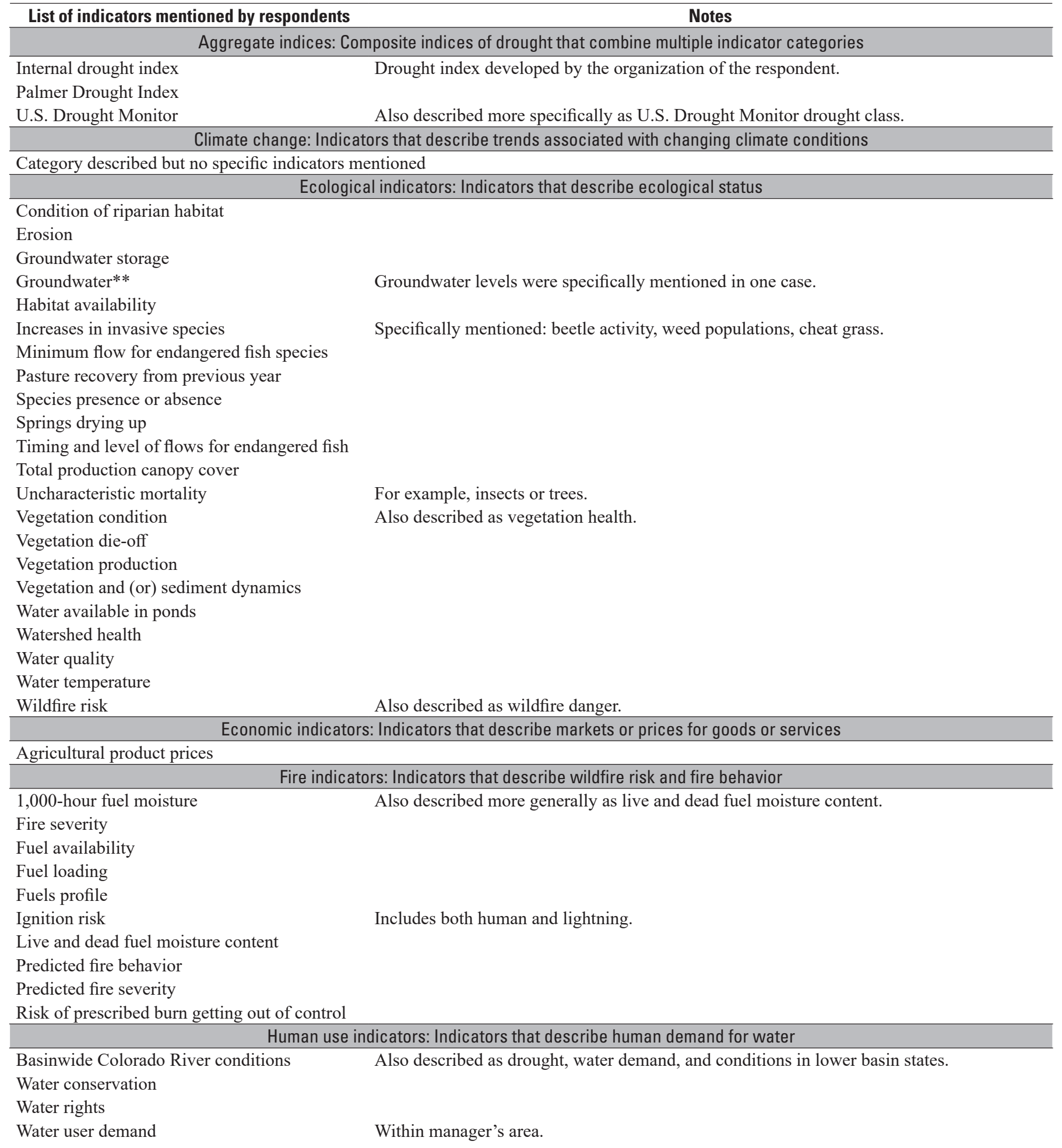


Table 1. Drought indicators reported by respondents.-Continued

[This table presents an aggregated list of indicators described by study respondents organized by general indicator category. Within the sublist for each category, indicators are sorted alphabetically. Indicators marked with ** appear in more than one category because different respondents mentioned it in different contexts]

\begin{tabular}{|c|c|}
\hline List of indicators mentioned by respondents & Notes \\
\hline \multicolumn{2}{|c|}{ Precipitation and snow indicators: Indicators that describe snow, rainfall, and runoff patterns } \\
\hline \multicolumn{2}{|l|}{ Forecast streamflow volume for April to July } \\
\hline \multicolumn{2}{|l|}{ Groundwater levels** } \\
\hline Monsoon timing** & Also described as monsoon onset. \\
\hline \multicolumn{2}{|l|}{ Percent normal precipitation and snowpack } \\
\hline Rainfall & Also mentioned specifically as summer monsoon rainfall. \\
\hline Runoff & Also described as melt timing. Some respondents specified runoff peak and (or) timing. \\
\hline \multicolumn{2}{|r|}{ 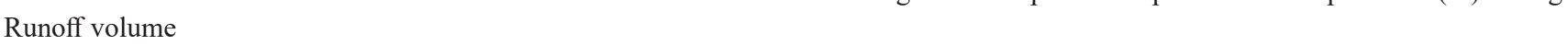 } \\
\hline Snow depth & Also described as winter snow cover. \\
\hline \multicolumn{2}{|l|}{ Snow water equivalent (SWE) } \\
\hline Forage nutrient production & Especially protein production. \\
\hline Forage quantity & Also described as available forage. \\
\hline \multicolumn{2}{|c|}{ Soil moisture: Indicators that describe or relate to soil moisture } \\
\hline
\end{tabular}

Effect on fire behavior

Effect on live fuel moistures

Effect on prescribed burn behavior

Moisture in soil available to vegetation Especially in spring as vegetation comes out of dormancy.

Percent average soil moisture

(Soil) Response to summer monsoons

Water supply indicators: Indicators that describe water available for human use

Annual volume of water through turbines for

hydropower generation

Carryover (reservoir) storage

Groundwater levels**

If junior water rights are fulfilled

Lake Powell water level

If the lake drops too low, hydropower generation becomes less efficient and eventually impossible.

Public lands water rights

Reservoir inflows

Reservoir levels

Return flows

$\quad$ Weather and climate indicators: Indicators that describe meteorological patterns
Deviations from normal
El Nino and La Nina
Monsoonal pattern**
Percentile weather conditions
Relative humidity
Solar input
Sun and solar heating
Temperature
Thunderstorms
Weather compared to historical conditions on
$\quad$ a given day
Weather patterns and storms
Wind


Table 2. Key indicators used in drought decision making.

[Abbreviations: BLM—Bureau of Land Management; Reclamation—Bureau of Reclamation; SWE—-snow-water equivalent; USFS—U.S. Forest Service; USFWS—U.S. Fish and Wildlife Service]

\begin{tabular}{|c|c|c|c|c|}
\hline $\begin{array}{l}\text { Decision } \\
\text { timeframe }^{1}\end{array}$ & Decision & Who makes decision & Key indicators used & $\begin{array}{l}\text { Report } \\
\text { section } \\
\text { describing }\end{array}$ \\
\hline Monthly or shorter & $\begin{array}{l}\text { Maintaining public and } \\
\text { firefighter safety while } \\
\text { suppressing wildfires }\end{array}$ & Fire management staff & $\begin{array}{l}\text { Air temperature, relative humidity, 1,000-hour fuel, Keetch-Byram Index, } \\
\text { human and lightning ignition risks, and sun exposure leading to solar } \\
\text { heating. }\end{array}$ & 3.1 .6 \\
\hline $\begin{array}{l}\text { Monthly or shorter } \\
\text { up to within a } \\
\text { water year }\end{array}$ & $\begin{array}{l}\text { Administering grazing } \\
\text { permits as drought } \\
\text { conditions change }\end{array}$ & $\begin{array}{l}\text { BLM and USFS rangeland management, } \\
\text { hydrology and ecology staff }\end{array}$ & Vegetation health and productivity. & 3.1 .3 \\
\hline $\begin{array}{l}\text { Monthly or shorter } \\
\text { up to within a } \\
\text { water year }\end{array}$ & $\begin{array}{l}\text { Understanding and } \\
\text { responding to changing } \\
\text { fire risk (for example, } \\
\text { allocating staff and } \\
\text { equipment resources) }\end{array}$ & Fire management staff & $\begin{array}{l}\text { Seasonal: percent normal precipitation and snowpack, snow depth, SWE, } \\
\text { runoff timing, summer streamflow, summer rainfall, monsoon onset, } \\
\text { and percent average soil moisture. Monthly or shorter: air temperature, } \\
\text { relative humidity, 1,000-hour fuel, Keetch-Byram Index, human and } \\
\text { lightening ignition risks, and sun exposure leading to solar heating. }\end{array}$ & 3.1 .5 \\
\hline Within a water year & $\begin{array}{l}\text { Annual water supply } \\
\text { operation and release } \\
\text { schedule }\end{array}$ & $\begin{array}{l}\text { Water project operator, Reclamation } \\
\text { (with input from USFWS, consump- } \\
\text { tive water users, whitewater boating } \\
\text { community) }\end{array}$ & $\begin{array}{l}\text { Reservoir levels, carryover reservoir storage, snowpack level in early } \\
\text { spring, SWE, runoff timing, and water demand. }\end{array}$ & 3.1 .1 \\
\hline Within a water year & $\begin{array}{l}\text { Managing prescribed } \\
\text { burns }\end{array}$ & $\begin{array}{l}\text { Fire management staff, land management } \\
\text { unit staff }\end{array}$ & $\begin{array}{l}\text { Relative humidity, air temperature, wind speed, predicted fire behavior, } \\
\text { 1,000-hour fuel moisture, and Keetch-Byram Index. These indicators are } \\
\text { often compared to thresholds laid out in prescribed burn plan. }\end{array}$ & 3.1 .4 \\
\hline Within a water year & $\begin{array}{l}\text { Staffing levels and person- } \\
\text { nel time allocation }\end{array}$ & $\begin{array}{l}\text { USFS and BLM fire managers, land } \\
\text { management unit technical specialists } \\
\text { managing field technicians or } \\
\text { temporary staff, State water agency } \\
\text { staff managing temporary or field staff }\end{array}$ & Range of indicators dependent on context. & 3.1 .6 \\
\hline Within a water year & $\begin{array}{l}\text { Visitor and recreational } \\
\text { management (for } \\
\text { example, issuing river } \\
\text { permits) }\end{array}$ & Land management unit staff & Range of indicators dependent on context. & 3.1 .6 \\
\hline
\end{tabular}


Table 2. Key indicators used in drought decision making.-Continued

[Abbreviations: BLM—Bureau of Land Management; Reclamation—Bureau of Reclamation; SWE—-snow-water equivalent; USFS—U.S. Forest Service; USFWS—U.S. Fish and Wildlife Service]

\begin{tabular}{|c|c|c|c|c|}
\hline $\begin{array}{l}\text { Decision } \\
\text { timeframe }\end{array}$ & Decision & Who makes decision & Key indicators used & $\begin{array}{l}\text { Report } \\
\text { section } \\
\text { describing }\end{array}$ \\
\hline $\begin{array}{l}\text { Within a water year } \\
\text { up to Longer } \\
\text { term }\end{array}$ & $\begin{array}{l}\text { Managing infrastructure } \\
\text { (for example, trans- } \\
\text { portation, park water } \\
\text { supply, and so forth) }\end{array}$ & Land management unit staff & Range of indicators dependent on context. & 3.1 .6 \\
\hline $\begin{array}{l}\text { Within a water year } \\
\text { up to longer term }\end{array}$ & $\begin{array}{l}\text { Timing and location of } \\
\text { hydropower generation } \\
\text { from Reclamation dams }\end{array}$ & Reclamation (WAPA staff market power) & $\begin{array}{l}\text { Water supply (including annual volume of water through turbines, reservoir } \\
\text { levels, Lake Powell level, reservoir inflow, and carryover storage) and } \\
\text { snow and precipitation (including snowpack and streamflow forecasts). }\end{array}$ & 3.1 .1 \\
\hline $\begin{array}{l}\text { Greater than } 5 \\
\text { years }\end{array}$ & $\begin{array}{l}\text { NEPA assessment for } \\
\text { projects }\end{array}$ & Land management unit staff & Projections based on a range of ecological indicators, and local monitoring. & 3.1 .2 \\
\hline $\begin{array}{l}\text { Greater than } 5 \\
\text { years }\end{array}$ & Issuing grazing permits & $\begin{array}{l}\text { BLM and USFS rangeland management, } \\
\text { hydrology and ecology staff }\end{array}$ & Long term vegetation health, and climate projections. & 3.1 .5 \\
\hline Longer term & Water supply planning & Water project operators, Reclamation & Projections of changing precipitation in a changing climate. & 3.1 .5 \\
\hline Longer term & $\begin{array}{l}\text { Drought preparedness } \\
\text { and formal drought } \\
\text { planning }\end{array}$ & $\begin{array}{l}\text { Water project operators, Reclamation, } \\
\text { BLM and USFS rangeland manage- } \\
\text { ment staff }\end{array}$ & Projections of climate change and associated impacts on resources. & 3.1 .5 \\
\hline Longer term & $\begin{array}{l}\text { Land management } \\
\text { planning (for example, } \\
\text { National Forest or } \\
\text { National Park Plan) }\end{array}$ & Land management unit staff & $\begin{array}{l}\text { Projections of climate change and associated impacts on land unit } \\
\text { resources. }\end{array}$ & 3.1 .5 \\
\hline Longer term & Land use planning & County government staff & $\begin{array}{l}\text { Population growth, and projections of climate change and associated } \\
\text { impacts. }\end{array}$ & 3.1 .5 \\
\hline Longer term & $\begin{array}{l}\text { Climate adaptation plan- } \\
\text { ning }\end{array}$ & $\begin{array}{l}\text { Land management unit staff, water } \\
\text { project operators, Reclamation }\end{array}$ & Projections of climate change and associated impacts. & 3.1 .5 \\
\hline
\end{tabular}
the 12 months. Thus, the year ending September 30, 1999 is called the "1999" water year." See https://water.usgs.gov/nwc/explain_data.html. For definitions of other timeframes, see Section 3 Codebook in the appendix. 
[Each column is described in more detail elsewhere in the text, as noted in the table footnotes. The profile types into which each respondent was inductively classified are described are described in Section 3.3. Abbreviations: BLM - Bureau of Land Management; CO—Colorado; CBRFC—Colorado Basin River Forecast Center; DOI—Department of the Interior; NCCASC—North Central Climate Adaptation Science Center; NIDIS - National Integrated Drought Information System; NOAA—National Oceanic and Atmospheric Administration; NPS—National Park Service; NRCS—Natural Resources Conservation Service; NWS—National Weather Service; RAWS—remote automatic weather stations; Reclamation—Bureau of Reclamation; RMCC—Rocky Mountain Area Coordination Center; SWE—snow-water equivalent; USFS - U.S. Forest Service; USGS-U.S. Geological Survey; USFWS—U.S. Fish and Wildlife Service; WAPA-Western Area Power Administration]

\begin{tabular}{|c|c|c|c|c|c|c|c|}
\hline $\begin{array}{c}\text { Conversation } \\
\text { number }\end{array}$ & $\begin{array}{l}\text { Respondent } \\
\text { description }\end{array}$ & $\begin{array}{l}\text { General decision } \\
\text { context }(s)^{2}\end{array}$ & $\begin{array}{l}\text { Decision } \\
\text { timing }^{2}\end{array}$ & $\begin{array}{l}\text { Key indicators } \\
\text { mentioned }^{3}\end{array}$ & $\begin{array}{l}\text { Key information sources, } \\
\text { products and tools mentioned }\end{array}$ & $\begin{array}{l}\text { Timeframe of } \\
\text { information } \\
\text { used }^{4}\end{array}$ & $\begin{array}{l}\text { How finds out about } \\
\text { new tools }\end{array}$ \\
\hline \multicolumn{8}{|c|}{ Profile type 1: Ecological } \\
\hline 1 & $\begin{array}{l}\text { NPS } \\
\text { administrator }\end{array}$ & $\begin{array}{l}\text { Planning, ecological } \\
\text { health, climate } \\
\text { change }\end{array}$ & $\begin{array}{l}\text { One to five } \\
\text { years, } \\
\text { longer term }\end{array}$ & $\begin{array}{l}\text { Ecological (groundwater, } \\
\text { erosion, species presence or } \\
\text { absence), climate change or } \\
\text { variability }\end{array}$ & $\begin{array}{l}\text { Ecological (unit resource } \\
\text { management plans, internal agency } \\
\text { technical specialists), fire (internal } \\
\text { agency technical specialist), } \\
\text { climate change (internal agency } \\
\text { technical specialist) }\end{array}$ & $\begin{array}{l}\text { Long term } \\
\text { projections, } \\
\text { one to five } \\
\text { year outlook }\end{array}$ & State or regional office \\
\hline 8 & $\begin{array}{l}\text { NPS } \\
\quad \text { administrator }\end{array}$ & $\begin{array}{l}\text { Ecological health, } \\
\text { fire management, } \\
\text { recreation }\end{array}$ & $\begin{array}{l}\text { Within a } \\
\text { water year, } \\
\text { longer term }\end{array}$ & $\begin{array}{l}\text { Snow and precipitation } \\
\text { (runoff peak, runoff } \\
\text { timing, winter snow cover, } \\
\text { summer monsoon rainfall), } \\
\text { ecological (vegetation } \\
\text { condition, habitat } \\
\text { availability, increases in } \\
\text { invasives), water supply } \\
\text { (park water rights) }\end{array}$ & $\begin{array}{l}\text { Weather and climate (local weather } \\
\text { stations), snow and precipitation } \\
\text { (snow pillows, snow course } \\
\text { measurements) }\end{array}$ & $\begin{array}{l}\text { Long term } \\
\text { projections, } \\
\text { seasonal, } \\
\text { esp. spring }\end{array}$ & $\begin{array}{l}\text { State or regional office, } \\
\text { DOI office }\end{array}$ \\
\hline 7 & $\begin{array}{l}\text { USFS technical } \\
\text { specialist }\end{array}$ & $\begin{array}{l}\text { Ecological health, } \\
\text { infrastructure, } \\
\text { climate change, } \\
\text { fire management, } \\
\text { personnel, } \\
\text { planning }\end{array}$ & $\begin{array}{l}\text { Longer term, } \\
\text { greater than } \\
5 \text { years }\end{array}$ & $\begin{array}{l}\text { Ecological (groundwater, } \\
\text { condition of riparian } \\
\text { habitat, water quality), } \\
\text { climate change or } \\
\text { variability, snow and } \\
\text { precipitation (snowpack, } \\
\text { melt timing) }\end{array}$ & $\begin{array}{l}\text { Ecological (internal agency technical } \\
\text { specialists, plans and guidance } \\
\text { documents, own monitoring), } \\
\text { climate change (impacts of } \\
\text { climate on elevation bands and } \\
\text { aspects, internal agency technical } \\
\text { specialist), snow and precipitation } \\
\text { (own monitoring, USGS gages, } \\
\text { NRCS summaries, SNOTEL) }\end{array}$ & $\begin{array}{l}\text { Long term } \\
\text { projections, } \\
\text { Seasonal } \\
\text { esp. spring }\end{array}$ & $\begin{array}{l}\text { State or regional office, } \\
\text { USFS library }\end{array}$ \\
\hline 10 & $\begin{array}{l}\text { USFWS } \\
\text { technical } \\
\text { specialist }\end{array}$ & $\begin{array}{l}\text { Ecological health, } \\
\text { planning }\end{array}$ & $\begin{array}{l}\text { Longer term, } \\
\text { within a } \\
\text { water year }\end{array}$ & $\begin{array}{l}\text { Ecological (timing and } \\
\text { level of flows for } \\
\text { endangered fish), snow and } \\
\text { precipitation (winter snow } \\
\text { cover, runoff peak, runoff } \\
\text { timing, spring and summer } \\
\text { streamflow) }\end{array}$ & $\begin{array}{l}\text { Snow and precipitation (CBRFC, } \\
\text { CCC updates, USGS gages, } \\
\text { Reclamation), aggregate indices } \\
\text { (U.S. Drought Monitor), water } \\
\text { supply (Reclamation and State } \\
\text { water models), climate change } \\
\text { (Reclamation and State water } \\
\text { models) }\end{array}$ & $\begin{array}{l}\text { Forecasts, } \\
\text { real time, } \\
\text { seasonal } \\
\text { esp. spring, } \\
\text { long term } \\
\text { projections }\end{array}$ & $\begin{array}{l}\text { Water manager } \\
\text { network, media, } \\
\text { upper basin State } \\
\text { agencies }\end{array}$ \\
\hline
\end{tabular}


Table 3. Decision context and timing, key indicators, and key information sources by respondent.—Continued

[Each column is described in more detail elsewhere in the text, as noted in the table footnotes. The profile types into which each respondent was inductively classified are described are described in Section 3.3. Abbreviations: BLM — Bureau of Land Management; CO—Colorado; CBRFC—Colorado Basin River Forecast Center; DOI—Department of the Interior; NCCASC—North Central Climate Adaptation Science Center; NIDIS - National Integrated Drought Information System; NOAA—National Oceanic and Atmospheric Administration; NPS—National Park Service; NRCS—Natural Resources Conservation Service; NWS - National Weather Service; RAWS—remote automatic weather stations; Reclamation—Bureau of Reclamation; RMCC—Rocky Mountain Area Coordination Center; SWE—snow-water equivalent; USFS—U.S. Forest Service; USGS—U.S. Geological Survey; USFWS—U.S. Fish and Wildlife Service; WAPA—Western Area Power Administration]

\begin{tabular}{|c|c|c|c|c|c|c|c|}
\hline $\begin{array}{c}\text { Conversation } \\
\text { number }\end{array}$ & $\begin{array}{l}\text { Respondent } \\
\text { description' }\end{array}$ & $\begin{array}{l}\text { General decision } \\
\text { context }(s)^{2}\end{array}$ & $\begin{array}{l}\text { Decision } \\
\text { timing }^{2}\end{array}$ & $\begin{array}{l}\text { Key indicators } \\
\text { mentioned }^{3}\end{array}$ & $\begin{array}{l}\text { Key information sources, } \\
\text { products and tools mentioned }\end{array}$ & $\begin{array}{c}\text { Timeframe of } \\
\text { information } \\
\text { used }^{4}\end{array}$ & $\begin{array}{l}\text { How finds out about } \\
\text { new tools }\end{array}$ \\
\hline \multicolumn{8}{|c|}{ Profile type 2: Fire } \\
\hline 23 & $\begin{array}{l}\text { USFS fire } \\
\text { technical } \\
\text { specialist }\end{array}$ & Fire management & $\begin{array}{l}\text { Within a } \\
\text { water year, } \\
\text { monthly or } \\
\text { shorter }\end{array}$ & $\begin{array}{l}\text { Weather and climate } \\
\text { (temperature, relative } \\
\text { humidity), fire (predicted } \\
\text { fire severity, risk of } \\
\text { prescribed burn getting out } \\
\text { of control, 1,000-hour fuel } \\
\text { moisture) }\end{array}$ & $\begin{array}{l}\text { Weather and climate (RAWS stations, } \\
\text { local sampling at prescribed burn } \\
\text { or fire site, NWS forecasts up } \\
\text { to } 10 \text { days, NOAA } 30 \text { \& 90-day } \\
\text { outlooks), aggregate indices } \\
\text { (Palmer Drought Index), fire } \\
\text { (Keetch-Byram), snow and } \\
\text { precipitation (SNOTEL, update } \\
\text { from interagency fire coordination } \\
\text { center, BLM employee-produced } \\
\text { climate and precipitation summary), } \\
\text { soil moisture (Keetch-Byram, local } \\
\text { sampling at prescribed burn site) }\end{array}$ & $\begin{array}{l}\text { Forecasts, } \\
\text { real time, } \\
\text { seasonal } \\
\text { esp. spring } \\
\text { and fall (for } \\
\text { prescribed } \\
\text { burning) }\end{array}$ & $\begin{array}{l}\text { RMCC, local NWS } \\
\text { office }\end{array}$ \\
\hline 27 & $\begin{array}{l}\text { USFS Fire } \\
\text { technical } \\
\text { specialist }\end{array}$ & $\begin{array}{l}\text { Fire management, } \\
\text { personnel }\end{array}$ & $\begin{array}{l}\text { Within a } \\
\text { water year, } \\
\text { monthly or } \\
\text { shorter }\end{array}$ & $\begin{array}{l}\text { Weather and climate } \\
\text { (percentile weather } \\
\text { conditions), fire (predicted } \\
\text { fire behavior, live and dead } \\
\text { fuel moisture content), } \\
\text { snow and precipitation } \\
\text { (percent normal } \\
\text { precipitation and snowpack, } \\
\text { snow depth, SWE, summer } \\
\text { streamflow, summer } \\
\text { rainfall), soil moisture } \\
\text { (effect on prescribed burn } \\
\text { behavior) }\end{array}$ & $\begin{array}{l}\text { Weather and climate (RAWS } \\
\text { stations), fire (Keetch-Byram, } \\
\text { local fuels monitoring), snow and } \\
\text { precipitation (SNOTEL, NRCS, } \\
\text { State of CO SWE, local rain } \\
\text { gages), soil moisture (Keetch- } \\
\text { Byram, local monitoring), } \\
\text { aggregate indices (U.S. Drought } \\
\text { Monitor) }\end{array}$ & $\begin{array}{l}\text { Real time, } \\
\text { seasonal esp. } \\
\text { spring and } \\
\text { summer }\end{array}$ & $\begin{array}{l}\text { RMCC, incident } \\
\text { meteorologists } \\
\text { from NWS, RAWS } \\
\text { technicians, } \\
\text { colleagues within } \\
\text { the forest }\end{array}$ \\
\hline 28 & $\begin{array}{l}\text { USFS fire } \\
\text { technical } \\
\text { specialist }\end{array}$ & Fire management & $\begin{array}{l}\text { Within a } \\
\text { water year, } \\
\text { monthly or } \\
\text { shorter }\end{array}$ & $\begin{array}{l}\text { Fire (fire severity, fuel } \\
\text { availability, live and dead } \\
\text { fuel moisture content), } \\
\text { snow and precipitation } \\
\text { (snowpack, monsoon } \\
\text { onset), soil moisture (effect } \\
\text { on live fuel moistures) }\end{array}$ & $\begin{array}{l}\text { Snow and precipitation (SNOTEL, } \\
\text { NRCS, Western Regional Climate } \\
\text { Center, Climate Prediction Center, } \\
\text { Advanced Hydrologic Prediction } \\
\text { Services from NWS), weather and } \\
\text { climate (RAWS stations), fire (local } \\
\text { sampling of fuel moistures, RMCC } \\
\text { webpage), aggregate indices (U.S. } \\
\text { Drought Monitor) }\end{array}$ & $\begin{array}{l}\text { Forecasts, } \\
\text { real time, } \\
\text { seasonal esp. } \\
\text { spring and } \\
\text { summer }\end{array}$ & $\begin{array}{l}\text { NOAA, NWS, Climate } \\
\text { Prediction Center }\end{array}$ \\
\hline
\end{tabular}


[Each column is described in more detail elsewhere in the text, as noted in the table footnotes. The profile types into which each respondent was inductively classified are described are described in Section 3.3. Abbreviations: BLM - Bureau of Land Management; CO—Colorado; CBRFC—Colorado Basin River Forecast Center; DOI—Department of the Interior; NCCASC—North Central Climate Adaptation Science Center; NIDIS - National Integrated Drought Information System; NOAA—National Oceanic and Atmospheric Administration; NPS—National Park Service; NRCS—Natural Resources Conservation Service; NWS—National Weather Service; RAWS—remote automatic weather stations; Reclamation—Bureau of Reclamation; RMCC—Rocky Mountain Area Coordination Center; SWE—snow-water equivalent; USFS - U.S. Forest Service; USGS-U.S. Geological Survey; USFWS—U.S. Fish and Wildlife Service; WAPA-Western Area Power Administration]

\begin{tabular}{|c|c|c|c|c|c|c|c|}
\hline $\begin{array}{c}\text { Conversation } \\
\text { number }\end{array}$ & $\begin{array}{l}\text { Respondent } \\
\text { description }{ }^{1}\end{array}$ & $\begin{array}{l}\text { General decision } \\
\text { context }(s)^{2}\end{array}$ & $\begin{array}{l}\text { Decision } \\
\text { timing }^{2}\end{array}$ & $\begin{array}{l}\text { Key indicators } \\
\text { mentioned }^{3}\end{array}$ & $\begin{array}{l}\text { Key information sources, } \\
\text { products and tools mentioned }\end{array}$ & $\begin{array}{c}\text { Timeframe of } \\
\text { information } \\
\text { used }^{4}\end{array}$ & $\begin{array}{l}\text { How finds out about } \\
\text { new tools }\end{array}$ \\
\hline \multicolumn{8}{|c|}{ Profile type 2: Fire-Continued } \\
\hline 29 & $\begin{array}{l}\text { USFS fire } \\
\text { technical } \\
\text { specialist }\end{array}$ & $\begin{array}{l}\text { Fire management, } \\
\text { infrastructure, } \\
\text { personnel }\end{array}$ & $\begin{array}{l}\text { Monthly or } \\
\text { shorter }\end{array}$ & $\begin{array}{l}\text { Weather and climate (weather } \\
\text { compared to historical } \\
\text { conditions on a given } \\
\text { day, temperature, relative } \\
\text { humidity, sun and solar } \\
\text { heating), fire (fuels profile, } \\
\text { fuel loading, 1,000-hour } \\
\text { fuel moisture), snow and } \\
\text { precipitation (snowpack, } \\
\text { runoff timing), soil } \\
\text { moisture (effect on fire } \\
\text { behavior) }\end{array}$ & $\begin{array}{l}\text { Weather and climate (RAWS } \\
\text { stations), fire (fire model FS Pro), } \\
\text { snow and precipitation (NRCS, } \\
\text { NOAA } 30 \& 90 \text {-day outlooks), } \\
\text { soil moisture (Keetch-Byram), } \\
\text { Aggregate Indices (Palmer } \\
\text { Drought Index, U.S. Drought } \\
\text { Monitor) }\end{array}$ & $\begin{array}{l}\text { Forecasts, } \\
\text { real time, } \\
\text { seasonal esp. } \\
\text { spring and } \\
\text { summer }\end{array}$ & RMCC, NWS, NOAA \\
\hline 30 & $\begin{array}{l}\text { Fire Interagency } \\
\text { Coordination } \\
\text { Center } \\
\text { employee }\end{array}$ & Fire management & $\begin{array}{l}\text { Monthly or } \\
\text { shorter }\end{array}$ & $\begin{array}{l}\text { Weather and climate } \\
\text { (temperature, relative } \\
\text { humidity, wind, } \\
\text { thunderstorms), snow and } \\
\text { precipitation (snowpack, } \\
\text { percent of average } \\
\text { precipitation, precipitation } \\
\text { timing and frequency, } \\
\text { SWE), fire (1,000-hour } \\
\text { fuel moisture, ignition risks } \\
\text { both human and lightning), } \\
\text { soil moisture (moisture in } \\
\text { soil available to vegetation } \\
\text { esp. in spring as vegetation } \\
\text { comes out of dormancy, } \\
\text { percent average soil } \\
\text { moisture) }\end{array}$ & $\begin{array}{l}\text { Snow and precipitation (NRCS, } \\
\text { NOAA), soil moisture (Climate } \\
\text { Prediction Center), fire (fire } \\
\text { models) }\end{array}$ & $\begin{array}{l}\text { Forecasts, } \\
\quad \text { real time, } \\
\text { seasonal esp. } \\
\text { spring }\end{array}$ & $\begin{array}{l}\text { Professional } \\
\text { association, “don't } \\
\text { always hear about } \\
\text { some of latest } \\
\text { research" }\end{array}$ \\
\hline
\end{tabular}


Table 3. Decision context and timing, key indicators, and key information sources by respondent.—Continued

[Each column is described in more detail elsewhere in the text, as noted in the table footnotes. The profile types into which each respondent was inductively classified are described are described in Section 3.3. Abbreviations: BLM — Bureau of Land Management; CO—Colorado; CBRFC—Colorado Basin River Forecast Center; DOI—Department of the Interior; NCCASC—North Central Climate Adaptation Science Center; NIDIS - National Integrated Drought Information System; NOAA—National Oceanic and Atmospheric Administration; NPS—National Park Service; NRCS—Natural Resources Conservation Service; NWS - National Weather Service; RAWS—remote automatic weather stations; Reclamation—Bureau of Reclamation; RMCC—Rocky Mountain Area Coordination Center; SWE—snow-water equivalent; USFS - U.S. Forest Service; USGS—U.S. Geological Survey; USFWS—U.S. Fish and Wildlife Service; WAPA—Western Area Power Administration]

\begin{tabular}{|c|c|c|c|c|c|c|c|}
\hline $\begin{array}{c}\text { Conversation } \\
\text { number }\end{array}$ & $\begin{array}{l}\text { Respondent } \\
\text { description' }\end{array}$ & $\begin{array}{l}\text { General decision } \\
\text { context }(s)^{2}\end{array}$ & $\begin{array}{l}\text { Decision } \\
\text { timing }^{2}\end{array}$ & $\begin{array}{l}\text { Key indicators } \\
\text { mentioned }^{3}\end{array}$ & $\begin{array}{l}\text { Key information sources, } \\
\text { products and tools mentioned }\end{array}$ & $\begin{array}{c}\text { Timeframe of } \\
\text { information } \\
\text { used }^{4}\end{array}$ & $\begin{array}{l}\text { How finds out about } \\
\text { new tools }\end{array}$ \\
\hline \multicolumn{8}{|c|}{ Profile type 3: Rangeland } \\
\hline 2 & $\begin{array}{l}\text { BLM } \\
\text { administrator }\end{array}$ & $\begin{array}{l}\text { Agriculture or } \\
\text { rangeland, } \\
\text { ecological health, } \\
\text { infrastructure, } \\
\text { planning, } \\
\text { recreation }\end{array}$ & $\begin{array}{l}\text { Greater than } \\
5 \text { years, } \\
\text { within a } \\
\text { water year }\end{array}$ & $\begin{array}{l}\text { Snow and precipitation (snow } \\
\text { depth, runoff timing, SWE), } \\
\text { soil moisture, weather } \\
\text { and climate indicators } \\
\text { (temperature, monsoonal } \\
\text { pattern) }\end{array}$ & $\begin{array}{l}\text { Snow and precipitation (NRCS), } \\
\text { Aggregate Indices (U.S. Drought } \\
\text { Monitor) }\end{array}$ & $\begin{array}{l}\text { Seasonal } \\
\text { especially } \\
\text { spring }\end{array}$ & $\begin{array}{l}\text { Supervisor, self- } \\
\text { exploration }\end{array}$ \\
\hline 13 & $\begin{array}{l}\text { BLM technical } \\
\text { specialist }\end{array}$ & $\begin{array}{l}\text { Agriculture or } \\
\text { rangeland, } \\
\text { ecological health, } \\
\text { planning }\end{array}$ & $\begin{array}{l}\text { Within a } \\
\text { water year }\end{array}$ & $\begin{array}{l}\text { Defined in drought plan: } \\
\text { snow and precipitation } \\
\text { (for example, streamflow), } \\
\text { ecological (for example, } \\
\text { vegetation condition), } \\
\text { aggregate indices (U.S. } \\
\text { Drought Monitor, Palmer } \\
\text { Drought Index), soil } \\
\text { moisture }\end{array}$ & $\begin{array}{l}\text { Weather and climate (local weather } \\
\text { stations), snow and precipitation } \\
\text { (local rain gages, SNOTEL, } \\
\text { NIDIS drought early warning } \\
\text { (DEWS) website), ecological } \\
\text { (local monitoring of vegetation } \\
\text { condition), aggregate indices (U.S. } \\
\text { Drought Monitor, Palmer Drought } \\
\text { Index), soil moisture (Veg DRI } \\
\text { Report) }\end{array}$ & $\begin{array}{l}\text { Seasonal } \\
\text { esp. spring } \\
\text { (timing } \\
\text { threshold } \\
\text { dates defined } \\
\text { in drought } \\
\text { plan) }\end{array}$ & $\begin{array}{l}\text { Colorado Climate } \\
\text { Center, NIDIS } \\
\text { network }\end{array}$ \\
\hline 15 & $\begin{array}{l}\text { BLM technical } \\
\text { specialist }\end{array}$ & $\begin{array}{l}\text { Agriculture or } \\
\text { rangeland, } \\
\text { ecological health, } \\
\text { planning }\end{array}$ & $\begin{array}{l}\text { Monthly or } \\
\text { shorter, } \\
\text { longer term }\end{array}$ & $\begin{array}{l}\text { Aggregate indices (U.S. } \\
\text { Drought Monitor drought } \\
\text { class), ecological } \\
\text { (vegetation production, } \\
\text { vegetation condition, } \\
\text { vegetation die-off), } \\
\text { snow and precipitation } \\
\text { (streamflow, water } \\
\text { available in ponds), weather } \\
\text { and climate (deviations } \\
\text { from normal) }\end{array}$ & $\begin{array}{l}\text { Aggregate indices (U.S. Drought } \\
\text { Monitor), weather and climate } \\
\text { (local weather stations), rangeland } \\
\text { (own monitoring of forage plants } \\
\text { once certain drought threshold is } \\
\text { reached) }\end{array}$ & Real time & $\begin{array}{l}\text { Colleagues in local } \\
\text { field office, State } \\
\text { or regional office, } \\
\text { nonfederal partners } \\
\text { in region, Colorado } \\
\text { Water Trust }\end{array}$ \\
\hline
\end{tabular}


[Each column is described in more detail elsewhere in the text, as noted in the table footnotes. The profile types into which each respondent was inductively classified are described are described in Section 3.3. Abbreviations: BLM - Bureau of Land Management; CO—Colorado; CBRFC—Colorado Basin River Forecast Center; DOI—Department of the Interior; NCCASC—North Central Climate Adaptation Science Center; NIDIS - National Integrated Drought Information System; NOAA—National Oceanic and Atmospheric Administration; NPS—National Park Service; NRCS—Natural Resources Conservation Service; NWS—National Weather Service; RAWS—remote automatic weather stations; Reclamation—Bureau of Reclamation; RMCC—Rocky Mountain Area Coordination Center; SWE—snow-water equivalent; USFS - U.S. Forest Service; USGS-U.S. Geological Survey; USFWS—U.S. Fish and Wildlife Service; WAPA-Western Area Power Administration]

\begin{tabular}{|c|c|c|c|c|c|c|c|}
\hline $\begin{array}{c}\text { Conversation } \\
\text { number }\end{array}$ & $\begin{array}{l}\text { Respondent } \\
\text { description }\end{array}$ & $\begin{array}{l}\text { General decision } \\
\text { context(s) }\end{array}$ & $\begin{array}{l}\text { Decision } \\
\text { timing }^{2}\end{array}$ & $\begin{array}{l}\text { Key indicators } \\
\text { mentioned }^{3}\end{array}$ & $\begin{array}{l}\text { Key information sources, } \\
\text { products and tools mentioned }\end{array}$ & $\begin{array}{c}\text { Timeframe of } \\
\text { information } \\
\text { used }^{4}\end{array}$ & $\begin{array}{l}\text { How finds out about } \\
\text { new tools }\end{array}$ \\
\hline \multicolumn{8}{|c|}{ Profile type 3: Rangeland-Continued } \\
\hline 19 & $\begin{array}{l}\text { NRCS technical } \\
\text { specialist }\end{array}$ & $\begin{array}{l}\text { Agriculture or } \\
\text { rangeland, } \\
\text { ecological health }\end{array}$ & $\begin{array}{l}\text { Within a } \\
\text { water year, } \\
\text { one to five } \\
\text { years }\end{array}$ & $\begin{array}{l}\text { Ecological (habitat availabil- } \\
\text { ity, vegetation condition, } \\
\text { total production canopy } \\
\text { cover), rangeland (forage } \\
\text { quantity, forage nutrient } \\
\text { production esp. protein), } \\
\text { snow and Precipitation } \\
\text { (snowpack, runoff, stream- } \\
\text { flow), economic (agricul- } \\
\text { tural products prices) }\end{array}$ & $\begin{array}{l}\text { Ecological (own monitoring esp. in } \\
\text { riparian areas, experiential knowl- } \\
\text { edge), snow and precipitation } \\
\text { (NRCS, USGS, local rain gages, } \\
\text { experiential knowledge), water } \\
\text { supply (NRCS reservoir forecasts), } \\
\text { soil moisture (local monitoring in } \\
\text { conjunction with snowgages, BLM } \\
\text { employee-produced climate and } \\
\text { precipitation summary) }\end{array}$ & $\begin{array}{l}\text { Forecasts, } \\
\text { seasonal esp. } \\
\text { spring }\end{array}$ & $\begin{array}{l}\text { Colleagues in other } \\
\text { Federal agency } \\
\text { offices in local area, } \\
\text { County extension, } \\
\text { State office }\end{array}$ \\
\hline 17 & $\begin{array}{l}\text { USFS technical } \\
\text { specialist }\end{array}$ & $\begin{array}{l}\text { Agriculture or } \\
\text { rangeland, } \\
\text { ecological health }\end{array}$ & $\begin{array}{l}\text { Longer term, } \\
\text { within a } \\
\text { water year }\end{array}$ & $\begin{array}{l}\text { Snow and precipitation } \\
\text { (runoff), ecological } \\
\text { (vegetation condition, } \\
\text { pasture recovery from } \\
\text { previous year, springs } \\
\text { drying up), aggregate } \\
\text { indices (U.S. Drought } \\
\text { Monitor), weather and } \\
\text { climate }\end{array}$ & $\begin{array}{l}\text { Ecological (own monitoring) range- } \\
\text { land (experiential knowledge of } \\
\text { staff and grazing permitees), snow } \\
\text { and precipitation (BLM employee- } \\
\text { produced climate and precipitation } \\
\text { summary, experiential knowl- } \\
\text { edge of staff, local rain and snow } \\
\text { gages), weather and climate (BLM } \\
\text { employee-produced climate and } \\
\text { precipitation summary, fire staff in } \\
\text { USFS office, local weather stations), } \\
\text { soil moisture (own qualitative } \\
\text { monitoring) }\end{array}$ & $\begin{array}{l}\text { Forecasts, } \\
\text { seasonal esp. } \\
\text { spring and } \\
\text { summer, real } \\
\text { time }\end{array}$ & $\begin{array}{l}\text { Colleagues in local } \\
\text { field office, State } \\
\text { or regional office, } \\
\text { professional } \\
\text { association }\end{array}$ \\
\hline 24 & $\begin{array}{l}\text { USFS technical } \\
\text { specialist }\end{array}$ & $\begin{array}{l}\text { Agriculture or } \\
\text { rangeland, } \\
\text { ecological health, } \\
\text { personnel, fire } \\
\text { management }\end{array}$ & $\begin{array}{l}\text { Within a } \\
\text { water year, }\end{array}$ & $\begin{array}{l}\text { Snow and precipitation } \\
\text { (runoff, monsoon timing), } \\
\text { rangeland (forage quantity), } \\
\text { ecological (uncharacteristic } \\
\text { mortality, for example, of } \\
\text { insects or trees), fire (live } \\
\text { and dead fuel moisture } \\
\text { content) }\end{array}$ & $\begin{array}{l}\text { Weather and climate (RMCC updates, } \\
\text { RAWS stations, long term weather } \\
\text { stations they maintain), snow and } \\
\text { precipitation (NRCS, CBRFC, up- } \\
\text { dates from local water conservation } \\
\text { district, USGS streamgages), aggre- } \\
\text { gate indices (Colorado Climate Cen- } \\
\text { ter updates, U.S. Drought Monitor), } \\
\text { rangeland (local forage availabil- }\end{array}$ & $\begin{array}{l}\text { Real time, } \\
\text { seasonal esp. } \\
\text { winter and } \\
\text { spring }\end{array}$ & $\begin{array}{l}\text { Western Water } \\
\text { Assessment, other } \\
\text { email lists, State or } \\
\text { regional office }\end{array}$ \\
\hline
\end{tabular}

rangeland (local forage availabil-

ity monitoring), ecological (local

stream temperature monitoring), fire

(local fuel moisture sampling) 
Table 3. Decision context and timing, key indicators, and key information sources by respondent.—Continued

[Each column is described in more detail elsewhere in the text, as noted in the table footnotes. The profile types into which each respondent was inductively classified are described are described in Section 3.3. Abbreviations: BLM — Bureau of Land Management; CO—Colorado; CBRFC—Colorado Basin River Forecast Center; DOI—Department of the Interior; NCCASC—North Central Climate Adaptation Science Center; NIDIS - National Integrated Drought Information System; NOAA—National Oceanic and Atmospheric Administration; NPS—National Park Service; NRCS—Natural Resources Conservation Service; NWS - National Weather Service; RAWS—remote automatic weather stations; Reclamation—Bureau of Reclamation; RMCC—Rocky Mountain Area Coordination Center; SWE—snow-water equivalent; USFS - U.S. Forest Service; USGS—U.S. Geological Survey; USFWS—U.S. Fish and Wildlife Service; WAPA-Western Area Power Administration]

\begin{tabular}{|c|c|c|c|c|c|c|c|}
\hline $\begin{array}{l}\text { Conversation } \\
\text { number }\end{array}$ & $\begin{array}{l}\text { Respondent } \\
\text { description' }\end{array}$ & $\begin{array}{l}\text { General decision } \\
\text { context }(s)^{2}\end{array}$ & $\begin{array}{l}\text { Decision } \\
\text { timing }^{2}\end{array}$ & $\begin{array}{l}\text { Key indicators } \\
\text { mentioned }^{3}\end{array}$ & $\begin{array}{l}\text { Key information sources, } \\
\text { products and tools mentioned }\end{array}$ & $\begin{array}{c}\text { Timeframe of } \\
\text { information } \\
\text { used }^{4}\end{array}$ & $\begin{array}{l}\text { How finds out about } \\
\text { new tools }\end{array}$ \\
\hline \multicolumn{8}{|c|}{ Profile type 4: Water Supply } \\
\hline 11 & $\begin{array}{l}\text { Reclamation } \\
\text { administrator }\end{array}$ & Water supply & $\begin{array}{l}\text { Longer term, } \\
\text { within a } \\
\text { water year }\end{array}$ & $\begin{array}{l}\text { Snow and precipitation } \\
\text { (runoff peak, runoff } \\
\text { timing), weather and } \\
\text { climate (temperature, El } \\
\text { Nino and La Nina), climate } \\
\text { change or variability, } \\
\text { human use (water user } \\
\text { demand) }\end{array}$ & $\begin{array}{l}\text { Weather and climate (NWS, NOAA), } \\
\text { snow and precipitation (CRBRC, } \\
\text { NRCS, experiential knowledge), } \\
\text { climate change or variability } \\
\text { ("Colorado River Basin Study"), } \\
\text { water supply (water models, dust } \\
\text { on snow research) }\end{array}$ & $\begin{array}{l}\text { Forecasts, } \\
\text { Seasonal } \\
\text { esp. Spring, } \\
\text { Long term } \\
\text { projections }\end{array}$ & CBRFC, NWS \\
\hline 3 & $\begin{array}{l}\text { Water } \\
\text { conservancy } \\
\text { employee }\end{array}$ & $\begin{array}{l}\text { Water supply, } \\
\text { recreation, } \\
\text { ecological health }\end{array}$ & $\begin{array}{l}\text { Within a } \\
\text { water year, } \\
\text { monthly or } \\
\text { shorter }\end{array}$ & $\begin{array}{l}\text { Water supply (reservoir levels, } \\
\text { carryover storage), snow } \\
\text { and precipitation (total } \\
\text { snowpack, SWE), weather } \\
\text { and climate (temperature), } \\
\text { human use (water user } \\
\text { demand) }\end{array}$ & $\begin{array}{l}\text { Snow and precipitation (CBRFC, } \\
\text { NRCS, SNOTEL, own monitoring, } \\
\text { Center for Snow \& Avalanche } \\
\text { Studies reports), soil moisture } \\
\text { (own monitoring), aggregate } \\
\text { indices (Colorado Climate Center } \\
\text { webinars), water supply (models } \\
\text { depicting how snowpack will } \\
\text { runoff) }\end{array}$ & $\begin{array}{l}\text { Seasonal esp. } \\
\text { spring, } \\
\text { forecasts }\end{array}$ & $\begin{array}{l}\text { Consultants, basin } \\
\text { roundtable, } \\
\text { Colorado Water } \\
\text { Congress }\end{array}$ \\
\hline 5 & $\begin{array}{l}\text { Water } \\
\text { conservancy } \\
\text { employee }\end{array}$ & $\begin{array}{l}\text { Water supply, } \\
\text { climate change }\end{array}$ & $\begin{array}{l}\text { Longer term } \\
\text { (up to } 40 \\
\text { years) }\end{array}$ & $\begin{array}{l}\text { Climate change or variability, } \\
\text { water supply (carryover } \\
\text { storage, groundwater levels, } \\
\text { return flows), human use } \\
\text { (water user demand locally, } \\
\text { basin wide Colorado River } \\
\text { conditions), snow and } \\
\text { precipitation (streamflow, } \\
\text { winter snowpack, timing } \\
\text { esp. fall and spring), } \\
\text { weather and climate } \\
\text { (temperature), ecological } \\
\text { (water quality, wildfire risk, } \\
\text { watershed health), }\end{array}$ & $\begin{array}{l}\text { Snow and precipitation (NRCS, } \\
\text { USGS streamgages, State of CO } \\
\text { gages, Reclamation, CBRFC, } \\
\text { SNOTEL, NOAA, experiential } \\
\text { knowledge about snowpack), } \\
\text { aggregate indices (Colorado } \\
\text { Climate Center updates), water } \\
\text { supply (CO River District risk } \\
\text { assessment scenario planning, dust } \\
\text { on snow research, State Water } \\
\text { Plan, experiential knowledge about } \\
\text { how runoff translates into reservoir } \\
\text { levels) }\end{array}$ & $\begin{array}{l}\text { Seasonal, } \\
\text { forecasts, } \\
\text { real time, } \\
\text { long term } \\
\text { projections }\end{array}$ & $\begin{array}{l}\text { Basin round table, } \\
\text { Colorado Water } \\
\text { Congress, other } \\
\text { State and interstate } \\
\text { water meetings for } \\
\text { example, Colorado } \\
\text { River water users }\end{array}$ \\
\hline
\end{tabular}


[Each column is described in more detail elsewhere in the text, as noted in the table footnotes. The profile types into which each respondent was inductively classified are described are described in Section 3.3. Abbreviations: BLM - Bureau of Land Management; CO—Colorado; CBRFC—Colorado Basin River Forecast Center; DOI—Department of the Interior; NCCASC—North Central Climate Adaptation Science Center; NIDIS—National Integrated Drought Information System; NOAA—National Oceanic and Atmospheric Administration; NPS—National Park Service; NRCS—Natural Resources Conservation Service; NWS—National Weather Service; RAWS—remote automatic weather stations; Reclamation—Bureau of Reclamation; RMCC—Rocky Mountain Area Coordination Center; SWE—snow-water equivalent; USFS - U.S. Forest Service; USGS - U.S. Geological Survey; USFWS—U.S. Fish and Wildlife Service; WAPA—Western Area Power Administration]

\begin{tabular}{|c|c|c|c|c|c|c|c|}
\hline $\begin{array}{c}\text { Conversation } \\
\text { number }\end{array}$ & $\begin{array}{l}\text { Respondent } \\
\text { description }\end{array}$ & $\begin{array}{l}\text { General decision } \\
\text { context(s) }\end{array}$ & $\begin{array}{l}\text { Decision } \\
\text { timing }^{2}\end{array}$ & $\begin{array}{l}\text { Key indicators } \\
\text { mentioned }^{3}\end{array}$ & $\begin{array}{l}\text { Key information sources, } \\
\text { products and tools mentioned }\end{array}$ & $\begin{array}{c}\text { Timeframe of } \\
\text { information } \\
\text { used }^{4}\end{array}$ & $\begin{array}{l}\text { How finds out about } \\
\text { new tools }{ }^{5}\end{array}$ \\
\hline \multicolumn{8}{|c|}{ Profile type 4: Water Supply_Continued } \\
\hline 6 & $\begin{array}{l}\text { Water } \\
\text { conservancy } \\
\text { employee }\end{array}$ & $\begin{array}{l}\text { Water supply, } \\
\text { climate change }\end{array}$ & $\begin{array}{l}\text { Longer term } \\
\text { (up to } 20 \\
\text { years), } \\
\text { Greater } \\
\text { than } 5\end{array}$ & $\begin{array}{l}\text { Climate change or variability, } \\
\text { snow and precipitation } \\
\text { (runoff), ecological } \\
\text { (wildfire risk), human use } \\
\text { (water user demand) }\end{array}$ & $\begin{array}{l}\text { Water supply (State Water Plan, dust } \\
\text { on snow research, research on how } \\
\text { permafrost affects runoff, research } \\
\text { on how beetle kill affects runoff, } \\
\text { research on how forest fires affect } \\
\text { runoff), snow and precipitation } \\
\text { (local water commissioner update), } \\
\text { climate change ("Colorado River } \\
\text { Basin Study") }\end{array}$ & $\begin{array}{l}\text { Long term } \\
\text { projections }\end{array}$ & $\begin{array}{l}\text { Colleagues in local } \\
\text { NF, Colorado Water } \\
\text { Congress, basin } \\
\text { roundtables, State } \\
\text { water agencies, } \\
\text { water commissioner }\end{array}$ \\
\hline 14 & $\begin{array}{l}\text { Water } \\
\text { conservancy } \\
\text { employee }\end{array}$ & $\begin{array}{l}\text { Water supply, } \\
\text { climate change, } \\
\text { recreation, } \\
\text { agricultural }\end{array}$ & $\begin{array}{l}\text { Within a } \\
\text { water year }\end{array}$ & $\begin{array}{l}\text { Water supply (if junior } \\
\text { water rights are met, } \\
\text { reservoir inflows, reservoir } \\
\text { levels, drought in lower } \\
\text { basin states), snow and } \\
\text { precipitation (streamflow, } \\
\text { snowpack) }\end{array}$ & $\begin{array}{l}\text { Snow and precipitation (CBRFC, } \\
\text { SNOTEL, anecdotal data from } \\
\text { users, Western Water Assessment } \\
\text { dashboard), weather and climate } \\
\text { (weather stations they sponsor), } \\
\text { water supply (Reclamation } \\
\text { reservoir operating schedules, } \\
\text { reservoir inflow forecast, State } \\
\text { of CO decision support system } \\
\text { (DSS)), aggregate indices (U.S. } \\
\text { Drought Monitor, Colorado } \\
\text { Climate Center webinars) }\end{array}$ & $\begin{array}{l}\text { Forecasts, } \\
\text { seasonal esp. } \\
\text { spring and } \\
\text { summer }\end{array}$ & $\begin{array}{l}\text { Colorado Climate } \\
\text { Center, CBRFC }\end{array}$ \\
\hline
\end{tabular}


Table 3. Decision context and timing, key indicators, and key information sources by respondent.—Continued

[Each column is described in more detail elsewhere in the text, as noted in the table footnotes. The profile types into which each respondent was inductively classified are described are described in Section 3.3. Abbreviations: BLM — Bureau of Land Management; CO—Colorado; CBRFC—Colorado Basin River Forecast Center; DOI—Department of the Interior; NCCASC—North Central Climate Adaptation Science Center; NIDIS - National Integrated Drought Information System; NOAA—National Oceanic and Atmospheric Administration; NPS—National Park Service; NRCS—Natural Resources Conservation Service; NWS - National Weather Service; RAWS—remote automatic weather stations; Reclamation—Bureau of Reclamation; RMCC—Rocky Mountain Area Coordination Center; SWE—snow-water equivalent; USFS - U.S. Forest Service; USGS—U.S. Geological Survey; USFWS—U.S. Fish and Wildlife Service; WAPA-Western Area Power Administration]

\begin{tabular}{|c|c|c|c|c|c|c|c|}
\hline $\begin{array}{c}\text { Conversation } \\
\text { number }\end{array}$ & $\begin{array}{l}\text { Respondent } \\
\text { description' }\end{array}$ & $\begin{array}{l}\text { General decision } \\
\text { context(s) }\end{array}$ & $\begin{array}{l}\text { Decision } \\
\text { timing }^{2}\end{array}$ & $\begin{array}{l}\text { Key indicators } \\
\text { mentioned }^{3}\end{array}$ & $\begin{array}{l}\text { Key information sources, } \\
\text { products and tools mentioned }\end{array}$ & $\begin{array}{c}\text { Timeframe of } \\
\text { information } \\
\text { used }^{4}\end{array}$ & $\begin{array}{l}\text { How finds out about } \\
\text { new tools }{ }^{5}\end{array}$ \\
\hline \multicolumn{8}{|c|}{ Profile type 4: Water Supply_Continued } \\
\hline 22 & $\begin{array}{l}\text { Water utility } \\
\text { employee }\end{array}$ & Water supply & $\begin{array}{c}\text { Longer term, } \\
\text { within a } \\
\text { water year }\end{array}$ & $\begin{array}{l}\text { Water supply (carryover } \\
\text { storage), snow and } \\
\text { precipitation (snowpack, } \\
\text { streamflow, SWE), } \\
\text { aggregate indices (U.S. } \\
\text { Drought Monitor, internal } \\
\text { drought index), human use } \\
\text { (water user demand, water } \\
\text { demand and conditions in } \\
\text { lower basin states), weather } \\
\text { and climate (temperature, } \\
\text { weather patterns and storms } \\
\text { esp. late spring), ecological } \\
\text { (water temperature) }\end{array}$ & $\begin{array}{l}\text { Snow and precipitation (CBRFC, } \\
\text { NRCS, own forecasting, SNOTEL, } \\
\text { USGS streamgages, State of CO } \\
\text { gages, Western Water Assessment } \\
\text { dashboard), water supply (State } \\
\text { of CO surface water supply index } \\
\text { (SWSI), water commissioners } \\
\text { on storage levels, internal water } \\
\text { operations model), aggregate } \\
\text { indices (U.S. Drought Monitor, } \\
\text { internal drought index, Colorado } \\
\text { Climate Center updates), } \\
\text { Weather and Climate (NOAA } \\
\text { global forecast system (GFS) } \\
\text { model, NOAA El Nino forecast, } \\
\text { Climate Prediction Center, 5280 } \\
\text { meteorology blog), human use } \\
\text { (Browning newsletter) }\end{array}$ & $\begin{array}{l}\text { Forecasts, } \\
\quad \text { real time, } \\
\text { seasonal esp. } \\
\text { spring }\end{array}$ & $\begin{array}{l}\text { State of CO Water } \\
\text { Availability Task } \\
\text { Force, Colorado } \\
\text { Climate Center, } \\
\text { CBRFC, Western } \\
\text { Water Assessment }\end{array}$ \\
\hline 25 & $\begin{array}{l}\text { Water utility } \\
\text { employee }\end{array}$ & Water supply & $\begin{array}{c}\text { Longer term, } \\
\text { within a } \\
\text { water year }\end{array}$ & $\begin{array}{l}\text { Water supply (reservoir } \\
\text { levels), human use (water } \\
\text { user demand), snow and } \\
\text { precipitation (predicted } \\
\text { streamflow volume for } \\
\text { April to July), weather and } \\
\text { climate (temperature) }\end{array}$ & $\begin{array}{l}\text { Snow and precipitation (CBRFC } \\
\text { and NRCS streamflow forecasts, } \\
\text { CBRFC runoff forecast, SNOTEL, } \\
\text { Climate Prediction Center seasonal } \\
\text { outlooks, USGS streamgages, } \\
\text { State of CO gages), water supply } \\
\text { (internal water models), human } \\
\text { use (internal models), weather } \\
\text { and climate (Western Water } \\
\text { Assessment dashboard) }\end{array}$ & $\begin{array}{l}\text { Forecasts, } \\
\text { real time, } \\
\text { seasonal esp. } \\
\text { spring and } \\
\text { summer }\end{array}$ & $\begin{array}{l}\text { Drought coordinator } \\
\text { within the } \\
\text { organization }\end{array}$ \\
\hline
\end{tabular}


[Each column is described in more detail elsewhere in the text, as noted in the table footnotes. The profile types into which each respondent was inductively classified are described are described in Section 3.3. Abbreviations: BLM - Bureau of Land Management; CO—Colorado; CBRFC—Colorado Basin River Forecast Center; DOI—Department of the Interior; NCCASC—North Central Climate Adaptation Science Center; NIDIS - National Integrated Drought Information System; NOAA—National Oceanic and Atmospheric Administration; NPS—National Park Service; NRCS—Natural Resources Conservation Service; NWS - National Weather Service; RAWS — remote automatic weather stations; Reclamation—Bureau of Reclamation; RMCC—Rocky Mountain Area Coordination Center; SWE—-snow-water equivalent; USFS - U.S. Forest Service; USGS-U.S. Geological Survey; USFWS—U.S. Fish and Wildlife Service; WAPA-Western Area Power Administration]

\begin{tabular}{|c|c|c|c|c|c|c|c|}
\hline $\begin{array}{l}\text { Conversation } \\
\text { number }\end{array}$ & $\begin{array}{l}\text { Respondent } \\
\text { description }{ }^{1}\end{array}$ & $\begin{array}{l}\text { General decision } \\
\text { context }(s)^{2}\end{array}$ & $\begin{array}{l}\text { Decision } \\
\text { timing }^{2}\end{array}$ & $\begin{array}{l}\text { Key indicators } \\
\text { mentioned }^{3}\end{array}$ & $\begin{array}{l}\text { Key information sources, } \\
\text { products and tools mentioned }\end{array}$ & $\begin{array}{c}\text { Timeframe of } \\
\text { information } \\
\text { used }^{4}\end{array}$ & $\begin{array}{l}\text { How finds out about } \\
\text { new tools }\end{array}$ \\
\hline \multicolumn{8}{|c|}{ Profile type 5: Not Managing for Drought As Such } \\
\hline 9 & $\begin{array}{l}\text { BLM technical } \\
\text { specialist }\end{array}$ & $\begin{array}{l}\text { Ecological health, } \\
\text { not managing for } \\
\text { drought }\end{array}$ & $\begin{array}{l}\text { Within a } \\
\text { water year, } \\
\text { longer term }\end{array}$ & $\begin{array}{l}\text { Snow and precipitation } \\
\text { (rainfall, monsoon events, } \\
\text { SWE), soil moisture, climate } \\
\text { change or variability, eco- } \\
\text { logical (groundwater levels) }\end{array}$ & $\begin{array}{l}\text { Snow and precipitation (own } \\
\text { monitoring inc. groundwater } \\
\text { wells, rain gages, snow tubes), } \\
\text { soil moisture (own qualitative } \\
\text { monitoring) }\end{array}$ & $\begin{array}{l}\text { Seasonal, one } \\
\text { to five year } \\
\text { outlook, } \\
\text { long term } \\
\text { projections }\end{array}$ & $\begin{array}{l}\text { Regional or State } \\
\text { office, Western } \\
\text { Water Assessment, } \\
\text { Colorado Climate } \\
\text { Center }\end{array}$ \\
\hline 18 & $\begin{array}{l}\text { County } \\
\text { government } \\
\text { employee }\end{array}$ & $\begin{array}{l}\text { Planning, fire } \\
\text { management, } \\
\text { recreation, } \\
\text { infrastructure, } \\
\text { climate change, } \\
\text { not managing for } \\
\text { drought }\end{array}$ & Longer term & $\begin{array}{l}\text { Climate change, human use } \\
\text { (water user demand, water } \\
\text { conservation), ecological } \\
\text { (wildfire risk), snow and } \\
\text { precipitation (snowpack, } \\
\text { runoff) }\end{array}$ & $\begin{array}{l}\text { Water supply (State Water Plan, } \\
\text { State of Colorado DSS), snow } \\
\text { and precipitation (SNOTEL), } \\
\text { Aggregate Indices (U.S. Drought } \\
\text { Monitor), Human Use (projected } \\
\text { buildout model) }\end{array}$ & $\begin{array}{l}\text { Seasonal, } \\
\text { long term } \\
\text { projections }\end{array}$ & $\begin{array}{l}\text { State water agencies, } \\
\text { water utilities, local } \\
\text { water commissioner, } \\
\text { professional } \\
\text { association }\end{array}$ \\
\hline 20 & $\begin{array}{l}\text { NPS technical } \\
\text { specialist }\end{array}$ & $\begin{array}{l}\text { Ecological health, } \\
\text { not managing for } \\
\text { drought }\end{array}$ & $\begin{array}{l}\text { Within a } \\
\text { water year, } \\
\text { longer term }\end{array}$ & $\begin{array}{l}\text { Ecological (groundwater } \\
\text { storage, springs drying } \\
\text { up, erosion and vegetation } \\
\text { dynamics), snow and } \\
\text { precipitation (snowpack, } \\
\text { snow volume as of May } \\
\text { 1, runoff volume, runoff } \\
\text { timing, rainfall), weather } \\
\text { and climate (temperature, } \\
\text { solar input), soil moisture } \\
\text { (response to summer } \\
\text { monsoons) }\end{array}$ & $\begin{array}{l}\text { Ecological indicators (own moni- } \\
\text { toring), snow and precipitation } \\
\text { (CBRFC runoff forecasts, error } \\
\text { of CBRFC from actual, USGS } \\
\text { streamgages, SNOTEL, local rain } \\
\text { gages), water supply (Reclama- } \\
\text { tion reservoir levels), weather and } \\
\text { climate (sponsored local weather } \\
\text { stations, other local weather sta- } \\
\text { tions), soil moisture (sponsored } \\
\text { local weather stations), aggregate } \\
\text { indices (Colorado Climate Center } \\
\text { updates) }\end{array}$ & $\begin{array}{l}\text { Forecasts, } \\
\text { seasonal esp. } \\
\text { spring }\end{array}$ & $\begin{array}{l}\text { Colleagues in other } \\
\text { Federal agency } \\
\text { offices in local } \\
\text { area, State water } \\
\text { agencies and their } \\
\text { meetings, local } \\
\text { water conservancy, } \\
\text { Reclamation staff }\end{array}$ \\
\hline 26 & $\begin{array}{l}\text { NPS technical } \\
\text { specialist }\end{array}$ & $\begin{array}{l}\text { Ecological health, } \\
\text { fire management, } \\
\text { not managing for } \\
\text { drought }\end{array}$ & Longer term & $\begin{array}{l}\text { Ecological (invasive species } \\
\text { including beetle activity, } \\
\text { weed populations, cheat } \\
\text { grass), climate change or } \\
\text { variability }\end{array}$ & $\begin{array}{l}\text { Snow and precipitation (Reclamation } \\
\text { determines relevant water } \\
\text { operations), ecological (local } \\
\text { monitoring), climate change } \\
\text { (scenario planning, NCCASC) }\end{array}$ & & $\begin{array}{l}\text { Colleagues within the } \\
\text { forest, colleagues in } \\
\text { other Federal agency } \\
\text { offices in local } \\
\text { area, nonfederal } \\
\text { partners in region, } \\
\text { Professional } \\
\text { associations }\end{array}$ \\
\hline
\end{tabular}


Table 3. Decision context and timing, key indicators, and key information sources by respondent.—Continued

[Each column is described in more detail elsewhere in the text, as noted in the table footnotes. The profile types into which each respondent was inductively classified are described are described in Section 3.3. Abbreviations: BLM — Bureau of Land Management; CO—Colorado; CBRFC—Colorado Basin River Forecast Center; DOI—Department of the Interior; NCCASC—North Central Climate Adaptation Science Center; NIDIS - National Integrated Drought Information System; NOAA—National Oceanic and Atmospheric Administration; NPS—National Park Service; NRCS—Natural Resources Conservation Service; NWS - National Weather Service; RAWS—remote automatic weather stations; Reclamation—Bureau of Reclamation; RMCC—Rocky Mountain Area Coordination Center; SWE—snow-water equivalent; USFS—U.S. Forest Service; USGS—U.S. Geological Survey; USFWS—U.S. Fish and Wildlife Service; WAPA—Western Area Power Administration]

\begin{tabular}{|c|c|c|c|c|c|c|c|}
\hline $\begin{array}{l}\text { Conversation } \\
\text { number }\end{array}$ & $\begin{array}{l}\text { Respondent } \\
\text { description }{ }^{1}\end{array}$ & $\begin{array}{l}\text { General decision } \\
\text { context }(s)^{2}\end{array}$ & $\begin{array}{l}\text { Decision } \\
\text { timing }^{2}\end{array}$ & $\begin{array}{l}\text { Key indicators } \\
\text { mentioned }^{3}\end{array}$ & $\begin{array}{c}\text { Key information sources, } \\
\text { products and tools mentioned }\end{array}$ & $\begin{array}{l}\text { Timeframe of } \\
\text { information } \\
\text { used }^{4}\end{array}$ & $\begin{array}{l}\text { How finds out about } \\
\text { new tools }\end{array}$ \\
\hline \multicolumn{8}{|c|}{ Profile type 5: Not Managing for Drought As Such—Continued } \\
\hline 4 & $\begin{array}{l}\text { State water } \\
\text { agency } \\
\text { employee }\end{array}$ & $\begin{array}{l}\text { Water supply, not } \\
\text { managing for } \\
\text { drought }\end{array}$ & $\begin{array}{l}\text { Monthly or } \\
\text { shorter }\end{array}$ & $\begin{array}{l}\text { Snow and precipitation } \\
\text { (streamflow, snowpack), } \\
\text { human use (water rights) }\end{array}$ & $\begin{array}{l}\text { Snow and precipitation (USGS } \\
\text { streamgages, Reclamation gages, } \\
\text { Tribal gages, NRCS, Reclamation, } \\
\text { CBRFC), water supply } \\
\text { (experiential knowledge about real } \\
\text { time water availability to water } \\
\text { rights holders) }\end{array}$ & $\begin{array}{l}\text { Forecasts, real } \\
\text { time }\end{array}$ & Not discussed \\
\hline 12 & $\begin{array}{l}\text { State water } \\
\text { agency } \\
\text { employee }\end{array}$ & $\begin{array}{l}\text { Personnel, water } \\
\text { supply, ecological } \\
\text { health (endangered } \\
\text { species), not } \\
\text { managing for } \\
\text { drought }\end{array}$ & $\begin{array}{l}\text { Within a } \\
\text { water year, } \\
\text { monthly or } \\
\text { shorter }\end{array}$ & $\begin{array}{l}\text { Water supply, snow and } \\
\text { precipitation, ecological } \\
\text { (minimum flow for } \\
\text { endangered fish species) }\end{array}$ & $\begin{array}{l}\text { Snow and precipitation (CBRFC, } \\
\text { NRCS), aggregate indices (U.S. } \\
\text { Drought Monitor, Colorado } \\
\text { Climate Center updates), water } \\
\text { supply (internal water model) }\end{array}$ & $\begin{array}{l}\text { Forecasts, } \\
\text { daily, } \\
\text { seasonal }\end{array}$ & $\begin{array}{l}\text { Reclamation, water } \\
\text { conservancies, other } \\
\text { CO water agencies, } \\
\text { larger water } \\
\text { municipalities }\end{array}$ \\
\hline 21 & $\begin{array}{l}\text { USFS technical } \\
\text { specialist }\end{array}$ & $\begin{array}{l}\text { Ecological health, } \\
\text { fire management, } \\
\text { climate change, } \\
\text { not managing for } \\
\text { drought }\end{array}$ & Longer term & $\begin{array}{l}\text { Ecological (vegetation } \\
\text { condition, wildfire risk), } \\
\text { weather and climate } \\
\text { (temperature, relative } \\
\text { humidity), snow and } \\
\text { precipitation (rainfall, } \\
\text { snowpack, streamflow) }\end{array}$ & $\begin{array}{l}\text { Weather and climate (NRCS Water } \\
\text { and Climate Update), snow and } \\
\text { precipitation (NRCS Water and } \\
\text { Climate Update, basin outlook } \\
\text { reports, USGS streamgages, State } \\
\text { of CO streamgages, SNOTEL), } \\
\text { aggregate indices (U.S. Drought } \\
\text { Monitor, Colorado Climate Center } \\
\text { updates) }\end{array}$ & $\begin{array}{l}\text { Historical } \\
\text { records, } \\
\text { real time, } \\
\text { long term } \\
\text { projections }\end{array}$ & $\begin{array}{l}\text { Colleagues within } \\
\text { same forest, State } \\
\text { and regional office, } \\
\text { USFS research } \\
\text { station, exploring } \\
\text { in course of own } \\
\text { research for specific } \\
\text { projects }\end{array}$ \\
\hline 31 & $\begin{array}{l}\text { WAPA } \\
\text { administrator }\end{array}$ & $\begin{array}{l}\text { Water supply } \\
\text { (marketing } \\
\text { hydropower) }\end{array}$ & $\begin{array}{l}\text { Within a } \\
\text { water year, } \\
\text { longer term } \\
\text { (up to } 40 \\
\text { years) }\end{array}$ & $\begin{array}{l}\text { Water supply (annual volume } \\
\text { of water through turbines, } \\
\text { reservoir levels, Lake } \\
\text { Powell level), snow and } \\
\text { precipitation (snowpack) }\end{array}$ & $\begin{array}{l}\text { Water supply (Reclamation 24-month } \\
\text { study, internal models), snow and } \\
\text { precipitation (SNOTEL) }\end{array}$ & $\begin{array}{l}\text { Seasonal, } \\
\text { forecasts, } \\
\text { real time }\end{array}$ & $\begin{array}{l}\text { Reclamation, State } \\
\text { water agency staff }\end{array}$ \\
\hline
\end{tabular}


[Each column is described in more detail elsewhere in the text, as noted in the table footnotes. The profile types into which each respondent was inductively classified are described are described in Section 3.3. Abbreviations: BLM - Bureau of Land Management; CO—Colorado; CBRFC—Colorado Basin River Forecast Center; DOI—Department of the Interior; NCCASC—North Central Climate Adaptation Science Center; NIDIS—National Integrated Drought Information System; NOAA—National Oceanic and Atmospheric Administration; NPS—National Park Service; NRCS—Natural Resources Conservation Service; NWS—National Weather Service; RAWS—remote automatic weather stations; Reclamation—Bureau of Reclamation; RMCC—Rocky Mountain Area Coordination Center; SWE—snow-water equivalent; USFS - U.S. Forest Service; USGS-U.S. Geological Survey; USFWS—U.S. Fish and Wildlife Service; WAPA-Western Area Power Administration]

\begin{tabular}{|c|c|c|c|c|c|c|c|}
\hline $\begin{array}{l}\text { Conversation } \\
\text { number }\end{array}$ & $\begin{array}{l}\text { Respondent } \\
\text { description }{ }^{1}\end{array}$ & $\begin{array}{c}\text { General decision } \\
\text { context }(\mathbf{s})^{2}\end{array}$ & $\begin{array}{l}\text { Decision } \\
\text { timing }^{2}\end{array}$ & $\begin{array}{l}\text { Key indicators } \\
\text { mentioned }^{3}\end{array}$ & $\begin{array}{l}\text { Key information sources, } \\
\text { products and tools mentioned }\end{array}$ & $\begin{array}{c}\text { Timeframe of } \\
\text { information } \\
\text { used }^{4}\end{array}$ & $\begin{array}{l}\text { How finds out about } \\
\text { new tools }\end{array}$ \\
\hline \multicolumn{8}{|c|}{ Profile type 5: Not Managing for Drought As Such-Continued } \\
\hline 16 & $\begin{array}{l}\text { WAPA technical } \\
\text { specialist }\end{array}$ & $\begin{array}{l}\text { Water supply } \\
\text { (marketing } \\
\text { hydropower) }\end{array}$ & $\begin{array}{l}\text { Within a } \\
\text { water year, } \\
\text { one to five } \\
\text { years }\end{array}$ & $\begin{array}{l}\text { Snow and precipitation } \\
\text { (streamflow forecast, } \\
\text { snowpack), water supply } \\
\text { (reservoir levels, reservoir } \\
\text { inflow, carryover storage), } \\
\text { aggregate indices (U.S. } \\
\text { Drought Monitor) }\end{array}$ & $\begin{array}{l}\text { Snow and precipitation (SNOTEL, } \\
\text { NOAA 90-day forecast), water } \\
\text { supply (Reclamation operations } \\
\text { model), aggregate indices (U.S. } \\
\text { Drought Monitor) }\end{array}$ & $\begin{array}{l}\text { Forecasts, real } \\
\text { time }\end{array}$ & Reclamation, CBRFC \\
\hline
\end{tabular}

${ }^{1}$ Respondents are described in Section 2.2 .

${ }^{2}$ Decision contexts and drought impacts of concern are described in Section 3.1 and summarized in table 2.

${ }^{3}$ Indicators relied on are described in Section 3.2 and summarized in table 1.

${ }^{4}$ Information sources, products, and tools used are described in Section 4.2 and table 4.

${ }^{5}$ How respondents find out about new tools is described in Section 5.1 . 


\subsection{Inductively-Derived "Profiles" of Drought Managers}

Based on the analysis of their drought impacts and indicators of interest (Section 3), the information sources on which they rely (Section 4), and the information networks and communities of practice to which they belong (Section 5), respondents were grouped into five profiles that describe types of drought managers. As described in Section 2.4, this qualitative data analysis technique may be considered conceptually analogous to a statistical cluster analysis, though the data in this study were not statistical. The results of this analysis suggest five distinct profiles with a degree of internal coherence in terms of the decision contexts in which they operate, the information on which they rely, and the information networks to which they belong. The profile type for each individual respondent appears in table 3. Descriptions of the five types are given here. These profiles provide an answer to the remark made by Redmond (2002, p. 1147) that droughts are like rainbows, with everyone experiencing their own version. In the UCRB, drought impacts appear to come in flavors that can be viewed as the colors of the rainbow, even if each individual might experience a slightly different shade of green or brown.

- Ecological managers are a subset of land managers concerned about the impact of drought on species and overall ecosystem health; the four participants classified in this category worked for NPS, USFS, and USFWS (though the USFWS employee worked closely with the Reclamation and as a result more closely resembled water managers in the way she used information). They made use of a wide range of indicators to assess ecological and species health, including groundwater, seeps and springs, habitat availability, invasive species, water availability for fish or other species, and flows for scouring vegetation or other geological processes. Four other respondents ultimately classified as "Not managing for drought" were also concerned about these impacts and made use of similar indicators, though a range of institutional constraints kept them from defining their roles as actively managing for drought (Section 3.1.7). They generally made decisions at longer time scales, either projects at the 1 to 10 year timescale that often require NEPA analysis, or longer-term resource planning looking more than 10 years ahead. Ecological managers are distinct in their heavy reliance on local monitoring, resource management plans or internal guidance documents, and other people within the agency as sources of information about drought and its impacts. This may be the result of the lack of current information products and tools available for understanding the ecological impacts of drought and (or) it may reflect the heterogeneous nature of the impact drought has on ecosystems, which can make developing more widely-applicable tools challenging.

- Fire managers are interested in the effect of drought on wildfire risk and fire behavior during prescribed burns and suppression operations. Their key indicators of interest include temperature, relative humidity, and live and dead fuel moistures, particularly the dead fuel moisture in 1,000-hour fuels. They rely on short-term weather and climate, short-term and seasonal precipitation, and short-term and seasonal fuel moisture information; key unique sources they described making use of include Remote Automatic Weather Stations (RAWS), fire models, and the Keetch-Byram Index. They also make use of extensive local monitoring and sampling at prescribed burn and wildfire sites to understand fuel moistures.

- Rangeland managers are a second subset of land managers who manage for vegetation condition and forage production within USFS, BLM, and NRCS. They rely on key indicators of vegetation health and productivity, streamflow, and soil moisture. They must balance short-term productivity desires of permittees with the need to maintain the long-term ecological health of the resources they manage. They reported relying on a combination of local monitoring and experiential knowledge (particularly focused on soil moisture), soil moisture information, aggregate indices, and snow and precipitation information. Rangeland managers were the only other group of users to describe making use of certain tools important to fire managers (for example, RAWS stations, RMCC updates). This may indicate a mutual interest in short-term soil moisture and (or) a close institutional tie (for example, within BLM offices; in a few cases even the same individual has job responsibilities that include both rangeland management and prescribed burns).

- Water supply managers are responsible for managing or supporting water supply operations, though they may play a range of roles in projects. Their key indicators include reservoir levels, carryover reservoir storage, the snowpack level in early spring, SWE, runoff timing, and human demand for water. They use a wide range of snow and precipitation, weather and climate, and water supply information and tools, as well as 28 information sources only mentioned by users in this category. They reported that they generally do not use soil moisture information, except so much as it is used as an input into runoff forecast models. Four mentioned soil moisture as a gap, noting that better soil moisture information could help with better prediction of net runoff.

- Managers who do not manage for drought as such: As described in Section 3.1.7, users in the study described three reasons they do not consider themselves to be managing for drought: (a) they have water management responsibilities that do not significantly change during drought conditions; (b) managing for drought requires a certain baseline understanding of resources and the impact that decreased water availability has on them, which some land management units do not currently have; or (c) managers do not have sufficient institutional control over water to make decisions that would influence how drought affects the resources they manage. In other words, managing for drought generally requires some understanding of or control of the link between drought exposure and response that these managers do not necessarily have. 


\section{Drought Information Sources and Tools}

Section 4 turns to the tools and information sources on which decision makers rely. Section 4.1 presents a conceptual framework to consider what use of information actually means. Section 4.2 links the indicators described in the previous section to specific sources of information, describing the agencies, information sources, tools, and people on which managers reported they depend to understand and manage for drought. Section 4.3 describes which managers reported using or not using three common categories of information: precipitation, soil moisture, and the U.S. Drought Monitor. A key theme that emerges in this section is redundancy; the same underlying dataset is often accessed in different ways or used for different purposes by different individuals, depending on the decisions they are making and the impacts or indicators of drought with which they are primarily concerned.

\subsection{A Note About Use of Drought Information}

In order to meet the broad aims of this study within the time constraints of the ethnographic conversations, respondents were asked questions about their use of drought information. Section 4.2 and 4.3 report findings about how respondents use information sources, products and tools in a generalized fashion without going into detail about differences of what use might mean in one context compared to another. While this is a useful shorthand that allows comparison across types of managers and decision contexts, it must be pointed out that it is also somewhat of a simplification.

In the report on "Using Science as Evidence in Public Policy," the National Research Council notes, "Many researchers underscore the conceptual confusion about [information] use and conclude that different definitions of use are needed and appropriate for different purposes (National Research Council, 2012, p. 37)." They point out that the usefulness of scientific information is determined by "whether it is informative about a very specific choice (NRC, 2012, p. 37)." In other words, use is not homogeneous; it means different things depending on context. The approach for this study approach uncovered significant detail about drought information sources, products, and tools respondents relied on, but most conversations did not include enough detail about how respondents used each type of information to differentiate between the multiple types of information use identified in the literature.

According to the studies reviewed by the NRC, however, the challenge of matching respondent descriptions of use to theoretical frameworks and typologies is not a surprising one. The NRC considers typologies that seek to categorize different ways decision makers use scientific evidence to be useful models, but cautions that in practice, a decision maker often cannot distinguish between the multiple categories of use delineated in a typology: "although typologies are heuristically valuable, they are not easily applied empirically. Boundaries are blurred, and access to users' cognitive processes is unattainable. In fact, it is unlikely that users themselves can make sharp distinctions in explaining how they use knowledge (NRC, 2012, p. 38)." Despite these conceptual limitations, a well-known typology of information use is presented here with corresponding examples from the study participants in order to emphasize the complexity of what using information means in practice.

According to the typology developed by Weiss and others (Weiss 1979; Weiss, Murphy-Graham, and Birkeland, 2005; NRC 2012), information use can take three distinct forms:

- Instrumental use is science or information that is "directly applied to decision making to address particular problems (NRC, 2012, p. 38)" (Sometimes a variant of instrumental use is broken out as imposed use, described as situations where information use is mandated or required.) The ways study participant use indicators to make specific decisions (described in Section 3) primarily represented examples of instrumental use. In a few cases respondents described imposed use of information, for instance the mandated use of formal triggers based on specific indicators in drought plans.

- Conceptual use is science or information that provides context, "influenc[ing] or inform[ing] how policy makers and practitioners think about issues, problems or potential solutions (NRC, 2012, p. 38)." Study respondents often described staying informed about indicators that they did not directly use to make decisions, indicating that UCRB DEWS tools frequently played conceptual or contextual roles. Even managers who described not having decision making authority to manage for drought (Section 3.1.7) described making use of precipitation and weather information to remain current about conditions in a general way. For instance, a county employee participating in the study described his conceptual use of information: "the 30,000-foot level is where we actually take our water and drought information. It's not an integral part of our planning on a day-to-day basis. We would more just utilize it and share it amongst ourselves and just have it as background knowledge for, let's say, when a developer comes in or if somebody has a question about drought-resistant landscaping and why we require it, or whatever else, we'd be able to share that information with 
them. It's not necessarily a specific thing that would be built into our day-to-day practice." Participants also frequently described using the U.S. Drought Monitor conceptually. For example, a State water agency employee stated, "Well, we look at the drought monitor, and-you know, that's just for an overall picture. Just because it's interesting. It's interesting to see where other States are within the Colorado River Basin, but again, we are not at this time administering the River Compact. We haven't had a need for it, so it's just more out of curiosity, I suppose."

- Tactical use is science or information is used tactically to justify, "support, or challenge an idea or program (NRC, 2012, p. 38)." Study participants described instances where drought information is used strategically to communicate and educate water users, board members, and (or) grazing permittees about current conditions, thereby making decisions based on scientific data more legitimate or politically feasible. Respondents mentioned using drought tools and forecasts to justify restrictions (such as shortage sharing on a Reclamation project or grazing permit modifications by the BLM) related to drought.

Throughout the rest of this section, results are reported for information use in aggregate. But this framework provides a reminder that there are nuances to how managers use information in practice.

\subsection{Drought Information Sources on Which Managers Rely}

Respondents described using a vast array of information sources, products, and tools to assist in preparing for, understanding the impacts of, and responding to drought. This section describes the information sources they discussed (including cases when the same underlying dataset was accessed through different websites or portals) and notes variation in tool use between different types of managers.

Information sources discussed by study participants were categorized into broad categories. Table 4 links these categories and specific information sources to the indicators described in Section 3. For the most part, the broad categories of information sources reported correspond to the broad categories of indicators identified in Section 3.2, though few specific tools were mentioned as sources of information for ecological or rangeland indicators. Instead, respondents reported they tend to rely on local monitoring and experiential or observational knowledge to assess ecological and rangeland indicators. This reliance likely reflects the relative paucity of available indicators for ecological impacts of drought (Section 3.2). It should also be noted that table 4 reports the experience of respondents in this study. Choices about information use are individual and thus a lack of a certain type of user using a certain source should not be interpreted to mean that source is not used by any of that type of user throughout the study region, simply that no user of that type within the sample reported using it.

\subsection{Using or Not Using Common Information Categories}

In the ethnographic conversations (with the exception of one conversation where this question was omitted due to time constraints; $\mathrm{n}=30$ in chart below), participants were also specifically asked whether they use or do not use three specific categories of commonly-used information: (a) precipitation information, including SNOTEL or snowpack data and real-time streamflow data, (b) soil moisture information, and (c) the U.S. Drought Monitor. In contrast to table 4, figure 5 emphasizes that various types of managers rely on quite similar basic information, especially precipitation information. Soil moisture information is less commonly used, with 14 of the 30 managers who answered this question reporting they use it. Note, however, a few water managers described indirect use of soil moisture when they noted that it is included in runoff forecasts. These individuals are not counted in this count of managers reporting the direct use of soil moisture monitoring or datasets.

\section{Summarized Use of Drought Information by User Type:}

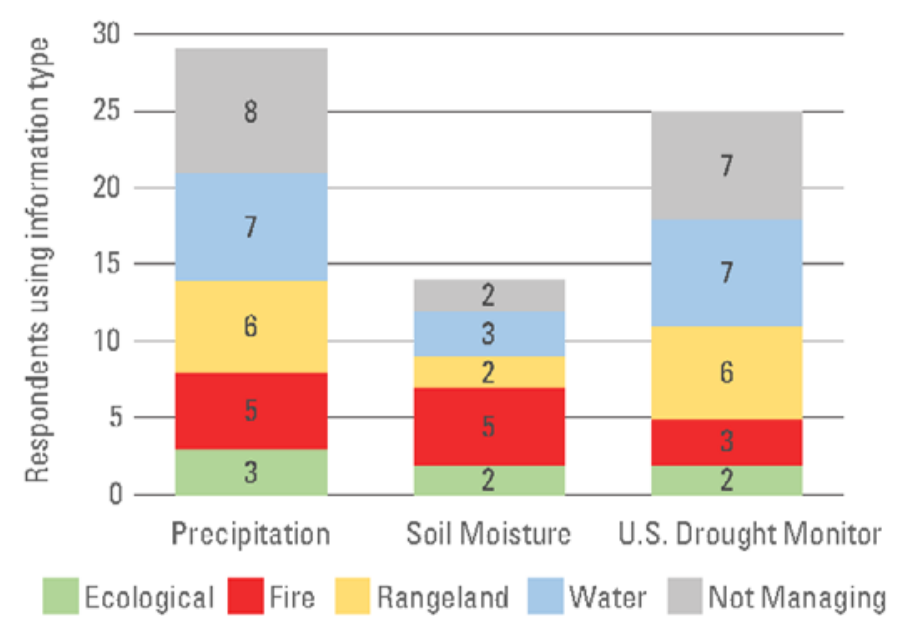

Figure 5. Summarized use of drought information by user profile. $\mathrm{N}=30$. Conversations with multiple staff from the same organization are treated as one respondent for this analysis. 
Taken together, table 4 and figure 5 suggest that different types of managers tend to access information through different channels, even if the underlying datasets or overarching types of information they rely on might be the same. For instance, water managers more frequently reported accessing information through the Colorado Basin River Forecast Center (CBRFC) website (as did one land manager who works closely with Reclamation to manage aquatic species). The CBRFC also provides runoff forecasts, which could explain the tendency of water managers to rely on it.

Section 5 describes how respondents reported discovering tools and the way information about drought data, information products, and tools flows within and across agencies. The same network characteristics that influence how participants find out about tools initially may also influence which websites they are more likely to turn to in order to obtain data. While redundant tools might seem inefficient, the variations in who uses which website suggests that repurposing the same datasets across agency websites and aggregate portals (for example, the WWA Intermountain West Climate Dashboard) may be a useful way to reach managers across agency affiliations and communities of practice. 
Table 4. Drought information sources used by different user types.

[Abbreviations: BLM — Bureau of Land Management; CBRFC—Colorado Basin River Forecast Center; CO—Colorado; NCCASC—North Central Climate Adaptation Science Center; NOAA—National Oceanic and Atmospheric Administration; NRCS—Natural Resources Conservation Service; NWS—National Weather Service; RAWS — remote automatic weather stations; Reclamation - Bureau of Reclamation; RMCC — Rocky Mountain Area Coordination Center; SWE—-snow-water equivalent; USFS—U.S. Forest Service]

\begin{tabular}{|c|c|c|c|c|c|c|c|}
\hline \multirow{2}{*}{$\begin{array}{l}\text { Information } \\
\text { type }^{1}\end{array}$} & \multirow{2}{*}{$\begin{array}{l}\text { Information items } \\
\text { mentioned }\end{array}$} & \multirow[b]{2}{*}{ Notes } & \multicolumn{5}{|c|}{ Type(s) of users reported using it ${ }^{2}$} \\
\hline & & & Ecological? & Fire? & Rangeland? & Water? & $\begin{array}{c}\text { Not } \\
\text { managing? }\end{array}$ \\
\hline \multicolumn{8}{|c|}{ Aggregate indicies: composite indicies of drought that combine one or more of the other categories } \\
\hline Product & U.S. Drought Monitor & & $\mathrm{X}$ & $\mathrm{X}$ & $\mathrm{X}$ & $\mathrm{X}$ & $\mathrm{X}$ \\
\hline Product & Colorado Climate Center Updates & Some respondents specified the webinars or web updates. & & & $\mathrm{X}$ & $\mathrm{X}$ & $\mathrm{X}$ \\
\hline Product & Palmer Drought Index & & & $\mathrm{X}$ & $\mathrm{X}$ & & \\
\hline Source & Internal drought index & Drought index developed by the organization of the respondent. & & & & $\mathrm{X}$ & \\
\hline \multicolumn{8}{|c|}{ Climate change or variability: tools or information sources that describe long term trends associated with changing climatic conditions and/or assess the impacts of these changes } \\
\hline Product & Colorado River Basin Study & & & & & $\mathrm{X}$ & \\
\hline Agency & Reclamation water models & & & & & $\mathrm{X}$ & \\
\hline Source & State water models & & & & & $\mathrm{X}$ & \\
\hline Source & scenario planning & & & & & & $\mathrm{X}$ \\
\hline Agency & NCCASC & & & & & & $\mathrm{X}$ \\
\hline Person & Agency technical specialist & & $\mathrm{X}$ & & & & \\
\hline Research & $\begin{array}{l}\text { Impacts of climate on elevation } \\
\text { bands and aspects }\end{array}$ & & $\mathrm{X}$ & & & & \\
\hline \multicolumn{8}{|c|}{ Ecological: tools or information sources that describe ecological health or response to drought } \\
\hline Source & Local monitoring & $\begin{array}{l}\text { Also described as monitoring by a management unit,. One respondent } \\
\text { specifically mentioned stream temperature monitoring, another } \\
\text { mentioned vegetation condition, another mentioned riparian habitats. }\end{array}$ & $\mathrm{X}$ & & $\mathrm{X}$ & & $\mathrm{X}$ \\
\hline Source & Experiential knowledge & & & & $\mathrm{X}$ & & \\
\hline Source & Unit resource management plans & & $\mathrm{X}$ & & & & \\
\hline Person & Agency technical specialist & Ecologist and hydrologist were specifically mentioned. & $\mathrm{X}$ & & & & \\
\hline \multicolumn{8}{|c|}{ Fire: tools or information sources describe wildfire risk and (or) predict wildfire behavior } \\
\hline Person & Agency technical specialist & & $\mathrm{X}$ & & & & \\
\hline Portal & RMCC webpage & & & $\mathrm{X}$ & & & \\
\hline Product & Keetch-Byram Index & & & $\mathrm{X}$ & & & \\
\hline Product & RMCC updates & & & $X$ & $\mathrm{X}$ & & \\
\hline Source & Fire models & FS Pro was specifically mentioned. & & $\mathrm{X}$ & & & \\
\hline Source & Local fuel moisture sampling & & & $X$ & $X$ & & \\
\hline Source & Local fuels monitoring & & & $\mathrm{X}$ & & & \\
\hline
\end{tabular}


Table 4. Drought information sources used by different user types.-Continued

[Abbreviations: BLM—Bureau of Land Management; CBRFC—Colorado Basin River Forecast Center; CO—Colorado; NCCASC—North Central Climate Adaptation Science Center; NOAA—National Oceanic and Atmospheric Administration; NRCS—Natural Resources Conservation Service; NWS—National Weather Service; RAWS — remote automatic weather stations; Reclamation —-Bureau of Reclamation; RMCC—Rocky Mountain Area Coordination Center; SWE—-snow-water equivalent; USFS—U.S. Forest Service]

\begin{tabular}{|c|c|c|c|c|c|c|c|}
\hline \multirow{2}{*}{$\begin{array}{l}\text { Information } \\
\text { type }^{1}\end{array}$} & \multirow{2}{*}{$\begin{array}{l}\text { Information items } \\
\text { mentioned }\end{array}$} & \multirow[b]{2}{*}{ Notes } & \multicolumn{5}{|c|}{ Type(s) of users reported using it ${ }^{2}$} \\
\hline & & & Ecological? & Fire? & Rangeland? & Water? & $\begin{array}{c}\text { Not } \\
\text { managing? }\end{array}$ \\
\hline \multicolumn{8}{|c|}{ Human use: tools or information sources describing human demand for water } \\
\hline Product & Browning newsletter & & & & & $\mathrm{X}$ & \\
\hline Source & Internal models & $\begin{array}{l}\text { One respondent specifically mentioned a projected land development } \\
\text { buildout model. }\end{array}$ & & & & $\mathrm{X}$ & $\mathrm{X}$ \\
\hline \multicolumn{8}{|c|}{ Precipitation and snow: tools or information sources that describe snow, rainfall, and runoff patterns } \\
\hline Agency & Reclamation & $\begin{array}{l}\text { One respondent specified that Reclamation determines relevant water } \\
\text { operations. }\end{array}$ & $\mathrm{X}$ & & $\mathrm{X}$ & $\mathrm{X}$ & \\
\hline Agency & CBRFC & & $\mathrm{X}$ & & $\mathrm{X}$ & $\mathrm{X}$ & $\mathrm{X}$ \\
\hline Agency & Climate Prediction Center & & & $\mathrm{X}$ & & $\mathrm{X}$ & \\
\hline Agency & NOAA & & & $\mathrm{X}$ & & $\mathrm{X}$ & \\
\hline Agency & NRCS & & $\mathrm{X}$ & $X$ & $X$ & $\mathrm{X}$ & $\mathrm{X}$ \\
\hline Agency & Western Regional Climate Center & & & $\mathrm{X}$ & & & \\
\hline Portals & $\begin{array}{l}\text { Upper Colorado drought early } \\
\text { warning website }\end{array}$ & & & & $\mathrm{X}$ & & \\
\hline Portals & $\begin{array}{l}\text { Western Water Assessment dash- } \\
\text { board }\end{array}$ & & & & & $\mathrm{X}$ & \\
\hline Product & $\begin{array}{l}\text { Advanced Hydrologic Prediction } \\
\text { Services from NWS }\end{array}$ & & & $\mathrm{X}$ & & & \\
\hline Product & Basin outlook reports & & & & & & $\mathrm{X}$ \\
\hline Product & $\begin{array}{l}\text { BLM employee-produced climate } \\
\text { and precipitation summary }\end{array}$ & This is sent by email to users in Gunnison area. & & $\mathrm{X}$ & $\mathrm{X}$ & & \\
\hline Product & CBRFC runoff forecast & One respondent mentioned calculating error of CBRFC from actual. & & & & $\mathrm{X}$ & $\mathrm{X}$ \\
\hline Product & $\begin{array}{l}\text { Center for Snow \& Avalanche } \\
\text { Studies reports }\end{array}$ & & & & & $\mathrm{X}$ & \\
\hline Product & $\begin{array}{l}\text { Climate Prediction Center seasonal } \\
\text { outlooks }\end{array}$ & & & & & $\mathrm{X}$ & \\
\hline Product & Local water commissioner update & & & & & $X$ & \\
\hline Product & NOAA 30 \& 90-day outlooks & & & $X$ & & & $X$ \\
\hline Product & NRCS Water and Climate Update & & & & & & $\mathrm{X}$ \\
\hline Product & SNOTEL & & $\mathrm{X}$ & $\mathrm{X}$ & $\mathrm{X}$ & $\mathrm{X}$ & $\mathrm{X}$ \\
\hline
\end{tabular}


Table 4. Drought information sources used by different user types.-Continued

[Abbreviations: BLM — Bureau of Land Management; CBRFC—Colorado Basin River Forecast Center; CO—Colorado; NCCASC—North Central Climate Adaptation Science Center; NOAA—National Oceanic and Atmospheric Administration; NRCS—Natural Resources Conservation Service; NWS—National Weather Service; RAWS-remote automatic weather stations; Reclamation —Bureau of Reclamation; RMCC—Rocky Mountain Area Coordination Center; SWE—-snow-water equivalent; USFS—U.S. Forest Service]

\begin{tabular}{|c|c|c|c|c|c|c|c|}
\hline \multirow{2}{*}{$\begin{array}{l}\text { Information } \\
\text { type }{ }^{1}\end{array}$} & \multirow{2}{*}{$\begin{array}{l}\text { Information items } \\
\text { mentioned }\end{array}$} & \multirow[b]{2}{*}{ Notes } & \multicolumn{5}{|c|}{ Type(s) of users reported using it $^{2}$} \\
\hline & & & Ecological? & Fire? & Rangeland? & Water? & $\begin{array}{c}\text { Not } \\
\text { managing? }\end{array}$ \\
\hline \multicolumn{8}{|c|}{ Precipitation and snow: tools or information sources that describe snow, rainfall, and runoff patterns - Continued } \\
\hline Product & Streamflow forecast, NRCS & & & & & $\mathrm{X}$ & \\
\hline Product & Streamflow forecast, CBRFC & & & & & $\mathrm{X}$ & \\
\hline Product & SWE (State of CO) & $\begin{array}{l}\text { Other users mentioned SWE as an indicator; this was the only specific } \\
\text { mention of where SWE data is obtained. }\end{array}$ & & $X$ & & & \\
\hline Product & Update from RMCC & & & $\mathrm{X}$ & $\mathrm{X}$ & & \\
\hline Product & $\begin{array}{l}\text { Update from local water conserva- } \\
\text { tion district }\end{array}$ & & & & $X$ & & \\
\hline Source & Experiential knowledge & $\begin{array}{l}\text { Also described more specifically as experiential knowledge of staff } \\
\text { or anecdotal data from users. Respondents specifically mentioned } \\
\text { experiential knowledge about snowpack. }\end{array}$ & & & $\mathrm{X}$ & $\mathrm{X}$ & $\mathrm{X}$ \\
\hline Source & Local rain gages & & & $\mathrm{X}$ & $\mathrm{X}$ & & $X$ \\
\hline Source & Local snow gages & & $\mathrm{X}$ & & $\mathrm{X}$ & & $\mathrm{X}$ \\
\hline Source & NRCS summaries & & $\mathrm{X}$ & & & & \\
\hline Source & Own forecasting & & & & & $\mathrm{X}$ & \\
\hline Source & Own monitoring & $\begin{array}{l}\text { One respondent specifically mentioned groundwater wells for } \\
\text { monitoring. }\end{array}$ & $\mathrm{X}$ & $\mathrm{X}$ & & & $\mathrm{X}$ \\
\hline Source & Snow course measurements & & $\mathrm{X}$ & & & & \\
\hline Source & Snow pillows & & $\mathrm{X}$ & & & & \\
\hline Source & Streamgages, Reclamation & & & & & & $\mathrm{X}$ \\
\hline Source & Streamgages, State of CO & & & & & $\mathrm{X}$ & $\mathrm{X}$ \\
\hline Source & Streamgages, Tribal & & & & & & $\mathrm{X}$ \\
\hline Source & Streamgages, USGS & & $\mathrm{X}$ & & $\mathrm{X}$ & $\mathrm{X}$ & $\mathrm{X}$ \\
\hline \multicolumn{8}{|c|}{ Rangeland: Tools or information sources that describe vegetation condition in context of grazing management } \\
\hline Source & $\begin{array}{l}\text { Experiential knowledge of staff } \\
\text { and grazing permitees }\end{array}$ & & & & $\mathrm{X}$ & & \\
\hline Source & $\begin{array}{l}\text { Local forage availability } \\
\text { monitoring }\end{array}$ & & & & $\mathrm{X}$ & & \\
\hline Source & $\begin{array}{l}\text { Own monitoring of forage plants } \\
\text { once certain drought threshold } \\
\text { is reached }\end{array}$ & & & & $X$ & & \\
\hline
\end{tabular}


Table 4. Drought information sources used by different user types.-Continued

[Abbreviations: BLM — Bureau of Land Management; CBRFC—Colorado Basin River Forecast Center; CO—Colorado; NCCASC—North Central Climate Adaptation Science Center; NOAA—National Oceanic and Atmospheric Administration; NRCS - Natural Resources Conservation Service; NWS—National Weather Service; RAWS-remote automatic weather stations; Reclamation —-Bureau of Reclamation; RMCC — Rocky Mountain Area Coordination Center; SWE—-snow-water equivalent; USFS—U.S. Forest Service]

\begin{tabular}{|c|c|c|c|c|c|c|c|}
\hline \multirow{2}{*}{$\begin{array}{l}\text { Information } \\
\text { type }^{1}\end{array}$} & \multirow{2}{*}{$\begin{array}{l}\text { Information items } \\
\text { mentioned }\end{array}$} & \multirow[b]{2}{*}{ Notes } & \multicolumn{5}{|c|}{ Type(s) of users reported using it ${ }^{2}$} \\
\hline & & & Ecological? & Fire? & Rangeland? & Water? & $\begin{array}{l}\text { Not } \\
\text { managing? }\end{array}$ \\
\hline \multicolumn{8}{|c|}{ Soil moisture: Tools or information sources describing or relating to soil moisture } \\
\hline Agency & Climate Prediction Center & & & $\mathrm{X}$ & & & \\
\hline Product & $\begin{array}{l}\text { BLM employee-produced climate } \\
\text { and precipitation summary }\end{array}$ & This is sent by email to users in Gunnison area. & & & $\mathrm{X}$ & & \\
\hline Product & Keetch-Byram Index & & & $\mathrm{X}$ & & & \\
\hline Product & Veg DRI Report & & & & $\mathrm{X}$ & & \\
\hline Source & Local monitoring & & & $\mathrm{X}$ & $\mathrm{X}$ & $\mathrm{X}$ & $\mathrm{X}$ \\
\hline Source & $\begin{array}{l}\text { Local sampling at prescribed burn } \\
\text { site }\end{array}$ & & & $\mathrm{X}$ & & & \\
\hline Source & $\begin{array}{l}\text { Sponsored weather stations that log } \\
\text { soil moisture }\end{array}$ & & & & & & $\mathrm{X}$ \\
\hline \multicolumn{8}{|c|}{ Water supply: Tools or information sources describing water available for human use } \\
\hline Person & $\begin{array}{l}\text { Water commissioners on storage } \\
\text { levels }\end{array}$ & & & & & $\mathrm{X}$ & \\
\hline Product & State of CO DSS & & & & & $\mathrm{X}$ & $\mathrm{X}$ \\
\hline Product & $\begin{array}{l}\text { State of CO Surface Water Supply } \\
\text { Index (SWSI) }\end{array}$ & & & & & $\mathrm{X}$ & \\
\hline Product & State of CO Water Plan & & & & & $\mathrm{X}$ & $\mathrm{X}$ \\
\hline Research & Beetle kill effect on runoff & & & & & $\mathrm{X}$ & \\
\hline Research & Dust on snow & & & & & $\mathrm{X}$ & \\
\hline Research & Forest fire effect on runoff & & & & & $\mathrm{X}$ & \\
\hline Research & Permafrost effect on runoff & & & & & $X$ & \\
\hline Source & Reclamation reservoir levels & & & & & & $\mathrm{X}$ \\
\hline Source & $\begin{array}{l}\text { Reclamation reservoir operating } \\
\text { schedules }\end{array}$ & & & & & $\mathrm{X}$ & \\
\hline Source & $\begin{array}{l}\text { Reclamation water (operations) } \\
\text { models }\end{array}$ & & $X$ & & & $\mathrm{X}$ & $X$ \\
\hline Source & $\begin{array}{l}\text { Colorado River District risk } \\
\text { assessment scenario planning }\end{array}$ & & & & & $\mathrm{X}$ & \\
\hline
\end{tabular}


Table 4. Drought information sources used by different user types.-Continued

[Abbreviations: BLM — Bureau of Land Management; CBRFC—Colorado Basin River Forecast Center; CO—Colorado; NCCASC—North Central Climate Adaptation Science Center; NOAA—National Oceanic and Atmospheric Administration; NRCS—Natural Resources Conservation Service; NWS—National Weather Service; RAWS — remote automatic weather stations; Reclamation —-Bureau of Reclamation; RMCC—Rocky Mountain Area Coordination Center; SWE—-snow-water equivalent; USFS—U.S. Forest Service]

\begin{tabular}{|c|c|c|c|c|c|c|}
\hline \multirow{2}{*}{$\begin{array}{l}\text { Information } \\
\text { type }^{1}\end{array}$} & \multirow{2}{*}{$\begin{array}{l}\text { Information items } \\
\text { mentioned }\end{array}$} & \multirow[b]{2}{*}{ Notes } & \multicolumn{4}{|c|}{ Type(s) of users reported using it ${ }^{2}$} \\
\hline & & & Fire? & Rangeland? & Water? & $\begin{array}{c}\text { Not } \\
\text { managing? }\end{array}$ \\
\hline \multicolumn{7}{|c|}{ Water supply: Tools or information sources describing water available for human use-Continued } \\
\hline Source & Experiential knowledge & $\begin{array}{l}\text { Also described more specifically as experiential knowledge of staff. } \\
\text { Respondents specifically mentioned experiential knowledge about } \\
\text { real time water availability to water rights holders, and how runoff } \\
\text { translates into reservoir levels. }\end{array}$ & & & $\mathrm{X}$ & $\mathrm{X}$ \\
\hline Source & Internal water models & $\begin{array}{l}\text { One respondent specified internal water operations model, one described } \\
\text { modeling to understand how snowpack will runoff. }\end{array}$ & & & $\mathrm{X}$ & \\
\hline Source & Reservoir inflow forecasts & & & & $\mathrm{X}$ & \\
\hline Source & State of CO water models & $\mathrm{X}$ & & & $\mathrm{X}$ & \\
\hline \multicolumn{7}{|c|}{ Weather and climate: tools or information sources that describe meteorological patterns } \\
\hline Agency & Climate Prediction Center & & & & $\mathrm{X}$ & \\
\hline Agency & NOAA & & $\mathrm{X}$ & & $\mathrm{X}$ & \\
\hline Agency & NWS & & & & $\mathrm{X}$ & \\
\hline Person & Fire staff in USFS office & & & $\mathrm{X}$ & & \\
\hline Portals & $\begin{array}{l}\text { Western Water Assessment dash- } \\
\text { board }\end{array}$ & & & & $X$ & \\
\hline Product & 5280 meteorology blog & & & & $\mathrm{X}$ & \\
\hline Product & $\begin{array}{l}\text { BLM employee-produced climate } \\
\text { and precipitation summary }\end{array}$ & & & $\mathrm{X}$ & & \\
\hline Product & RMCC updates & & & $\mathrm{X}$ & & \\
\hline Product & NOAA $30 \&$ 90-day outlooks & & $\mathrm{X}$ & & & \\
\hline Product & NOAA El Nino forecast & & & & $\mathrm{X}$ & \\
\hline Product & $\begin{array}{l}\text { NOAA global forecast system } \\
\text { (GFS) model }\end{array}$ & & & & $X$ & \\
\hline Product & NRCS Water and Climate Update & & & & & $\mathrm{X}$ \\
\hline Product & NWS forecasts up to 10 days & & $\mathrm{X}$ & & & \\
\hline Source & $\begin{array}{l}\text { Local sampling at prescribed burn } \\
\text { or fire site }\end{array}$ & & $\mathrm{X}$ & & & \\
\hline
\end{tabular}


Table 4. Drought information sources used by different user types.-Continued

[Abbreviations: BLM —Bureau of Land Management; CBRFC—Colorado Basin River Forecast Center; CO—Colorado; NCCASC—North Central Climate Adaptation Science Center; NOAA—National Oceanic and Atmospheric Administration; NRCS—Natural Resources Conservation Service; NWS-National Weather Service; RAWS-remote automatic weather stations; Reclamation - Bureau of Reclamation; RMCC—-Rocky Mountain Area Coordination Center; SWE—-snow-water equivalent; USFS—U.S. Forest Service]

\begin{tabular}{|c|c|c|c|c|c|c|c|}
\hline \multirow[b]{2}{*}{$\begin{array}{l}\text { Information } \\
\text { type }^{1}\end{array}$} & \multirow{2}{*}{$\begin{array}{l}\text { Information items } \\
\text { mentioned }\end{array}$} & \multirow[b]{2}{*}{ Notes } & \multicolumn{5}{|c|}{ Type(s) of users reported using it ${ }^{2}$} \\
\hline & & & Ecological? & Fire? & Rangeland? & Water? & $\begin{array}{c}\text { Not } \\
\text { managing? }\end{array}$ \\
\hline \multicolumn{8}{|c|}{ Weather and climate: tools or information sources that describe meteorological patterns-Continued } \\
\hline Source & Local weather stations & $\begin{array}{l}\text { Two respondents noted their organizations sponsor weather stations. } \\
\text { One respondent emphasized the unit has maintained a station long } \\
\text { term. }\end{array}$ & $\mathrm{X}$ & & $\mathrm{X}$ & $\mathrm{X}$ & $\mathrm{X}$ \\
\hline Source & RAWS stations & & & $\mathrm{X}$ & $\mathrm{X}$ & & \\
\hline
\end{tabular}

${ }^{1}$ Definitions of information types: Product—a specific information source mentioned by name; Source—general type of product mentioned in aggregate by respondent; Agency—an agency or organization mentioned as providing information when no further details were given about which specific products or sources are used; Person-respondent described getting information from another person, for example, another technical specialist in their unit; Portals—-tools or websites that aggregate other information sources; Research—scientific research.

${ }^{2}$ User profile types are described in Section 3.3 . 


\section{Selecting Among Available Drought Tools}

This section describes how managers find out about available tools or information sources and how they evaluate usability. Section 5.1 reports the means by which respondents find out about drought, weather, and climate information and tools. One key difference that emerged was the strong interagency networks that existed among water managers and fire managers juxtaposed with the tendency for information to move vertically among those managing nonfire resources within each of the land management agencies. Some individuals also reported experiencing a frustrating lack of integration into any kind of information network. Almost all participants in the study agreed on the basic factors that affect information usability (Section 5.2): they preferred tools that are easy to use and relevant to their management challenges, though their specific contexts determined what those challenges might be. Conversely, reported reasons for not using available tools also included the need for context-specific decision support (Section 5.3).

\subsection{How Managers Find Out About Drought Information and Tools}

Respondents were asked to describe how they generally find out about new information sources or tools and to identify the people, listservs, or other methods that are most important for keeping them informed. Their responses reveal distinct patterns in the way different types of decision makers stay informed about drought, weather, climate and related topics.

\subsubsection{Intra-Agency Relationships}

Respondents from the NPS, BLM, and USFS (in nonfire roles) reported that other people in their own agency were their primary means of learning about drought information sources or tools. They relied on information passed to them from their management as well as suggested to them by peers.

The formal hierarchy of their agencies seems to have shaped how these respondents sought information. One NPS administrator described how "starting with the regional office usually is the first place I would make a phone call. Then if I couldn't find somebody who had the expertise, they were usually very helpful in directing me to the next place I could go to try to find that expertise." A BLM technical specialist in a field office emphasized the importance of her State office in disseminating information:

"I think you got the picture that we get a lot of information being passed on down to us. If you're interested in making sure that information gets used by people in the field, then you've got to find a way to make it stand out from the other information. You probably surmise that we have a hierarchical structure, and our state office is pretty important at disseminating information. Somehow you've got to make your product more important in their eyes. They will go the extra yard to get it into our hands and emphasize that they expect us to use it."

These same respondents also highlighted the importance of their colleagues with responsibility for different resources. Particularly within the national forests, where responsibility for drought can be spread across multiple job descriptions (for example, hydrologist, soil scientist, rangeland management specialist, and so forth), colleagues within an office can also be an important source of information. A USFS technical specialist in a district office described this interplay: "it could come from another specialist, the hydrologist, or soil scientists on the forest, or our regional office." Another USFS technical specialist in an office of a forest supervisor emphasized that information being distributed from higher up in the agency results in his seeing a broader set of sources than he might have otherwise encountered:

"I am most likely to find out about new sources of information if they are pushed to me. I think that I probably end up with a broader range. If I'm seeking information, it generally tends to be in a pretty small box so that the sources that I end up identifying for that information are very specific to a specific question***information that comes down from my counterparts in the regional office, there's probably a broader scope of information, some of which is not particularly useful and I dismiss, and others which may be useful but which I would not [necessarily] consider [myself] ***it'd be fairly serendipitous if I ran into some of this stuff because I was seeking that information."

For these land managers, others in their agency are a primary means of finding new information. 


\subsubsection{Interagency Relationships}

In contrast, water managers and BLM or USFS respondents in fire management roles emphasized the importance of their respective communities of practice in keeping them informed. A community of practice is a group of people "informally bound together by shared expertise and passion for a joint enterprise***people in communities of practice share their experiences and knowledge in free-flowing, creative ways that foster new approaches to problems (Wenger and Snyder 2000, p. 139).” The cross-organization relationships described by water managers and fire managers fit this definition.

Participant water managers hold a range of roles, but all described strong ties to others who manage water, including water project operators, water conservancy and water conservation district staff, State water agency staff, and Reclamation staff. These ties cross jurisdictional boundaries, including local, State, Federal, and private organizations as well as scientists and practitioners employed by non-governmental organizations. An employee for a water project summarized these connections:

"the water world is pretty well networked, informationally. There's regular communication throughout most people throughout our basin. Then all the stuff that flows through the [Basin] Roundtable process. We go to [the Colorado] Water Congress. I go twice a year***summer and winter***[it's a] great source of information. When the Colorado River District puts their annual seminar on, a lot of times I'm on a panel. I'm on panels at most of these gatherings."

A number of other respondents emphasized the importance of the Colorado Water Congress, which is both a biannual conference and a nonprofit organization that has worked since 1958 to "to initiate and advance programs to conserve, develop, administer, and protect the water resources of the State of Colorado" (Colorado Water Congress, 2018) With more than 400 member organizations, the Colorado Water Congress is a representation of the vibrant interagency community of practice described by water managers participating in this study.

Respondents described other ways that this community of practice is created and maintained, including information sharing through the water conservancies and local water commissioners (both one-on-one and at meetings), attendance at multistate Colorado River Basin policymaking meetings, working in partnership with the Reclamation as it administers Federal projects, and even learning by working with consultants (for example, to build a water model). In a few cases, respondents from the land management agencies also described being integrated into this community of practice, such as a USFS technical specialist in the San Juan Basin and a USFWS employee working with endangered fish.

Respondents in fire management roles also described a community of practice, but a more formal one focused around the interagency coordination center (that is, Rocky Mountain Area Coordination Center [RMCC]). Fire managers in the BLM and USFS offices relied on this community to provide both real-time information during incidents (Section 4.2) as well as keep them informed about existing resources. They particularly highlighted the importance of the predictive services division within the RMCC, pointing out that fire meteorologists are a primary source of drought, weather, and climate information for staff in field and district offices. Both the field level staff as well as the meteorologists closely coordinate with the National Weather Service, both for understanding seasonal outlooks and when NWS staff serve as incident meteorologists for larger fires. An Fire Interagency Coordination Center employee summarized the fire community of practice:

"[Information] dissemination goes to the fire management within the land agencies, which also includes federal agencies, state agencies, and it goes down to the local units. Our main focus is a regional level commitment to fire managers, so the managers that are making those resource decisions at a regional level and national level. However, over time, what we are providing has also been utilized at the field level, so the firefighters on the ground***The state level is also using that. I interact with the State of Colorado, for example, on a regular basis***It's pretty broad in terms of agency level. One thing we have in common is the fire community."

One USFS fire manager described how the fire management community of practice intersects with intra-agency information sharing:

"Our forest hydrologists and [other technical specialists rely on information distributed by RMCC]***drought maps get posted and if something is of interest or kind of an anomaly, we'll forward stuff around to everybody and see if different people latch onto it. It gets passed around and if it's a bigger scale thing, it'll get passed around from forest to forest, or even our entire region will get ahold of that."

This point about the important role that "the fire folks down the hall" have in disseminating information from the fire community to nonfire staff in their offices was echoed by both fire managers and BLM and USFS managers in nonfire roles who participated in the study. 


\subsubsection{Place-Based Networks}

A third set of relationships described by participants are those with others working in the same geographical region. These networks can be considered a place-based community of practice. Respondents in the Gunnison River Basin (Colorado Division 4) particularly highlighted the strength of ties in their local area. An NPS technical specialist described her experience as part of the Gunnison River Basin working group. Sponsored by the DOI North Central Climate Adaptation Science Center, the group used scenario planning to consider possible climate change adaptation strategies (Rondeau and others, 2017). This employee emphasized that she

"learned a lot through that project as far as anticipating, and/or setting up some things that we could do to maybe make our landscape a little bit more resilient in some areas***That information from that working group was really good in that it has sparked some actual project work on the ground***The working group has been probably the most, I think, applicable [source of information] to our area, to our regional situation, to our regional resources, to the sagegrouse, to sage-grouse habitat improvements, things that since the listing of Gunnison sage-grouse have been really important."

The scenario planning described in the above quote focused on a working group implemented for a specific project, but three other respondents in the same Gunnison River Basin discussed another example that suggests longer-term integration within this area. When asked what information sources they rely on, a USFS technical specialist, a USFS fire manager, and an NRCS employee working in the Gunnison described a regional quarterly climate summary and outlook produced and distributed by a BLM hydrologist. This regional information product had been developed in response to local needs and users reported it was one of their go-to information sources. Its existence and use points to the existence of a robust place-based network (Williams, Stewart, and Kruger, 2013) for sharing knowledge and resources in the Gunnison Basin.

\subsubsection{Outreach}

In addition to relying on people to stay informed, participants relied on a range of other outreach methods from agencies producing information, boundary organizations (that is, organizations that link information producers and users; Dilling and Lemos, 2011), and professional associations. Respondents mentioned professional conferences and listservs (such as the Society for Rangeland Management, the American Planning Association, or the biannual High Altitude Revegetation and Ecological Restoration workshop); workshops hosted by or updates distributed from Western Water Assessment, the Colorado Climate Center, and similar organizations; receiving hard copy information (for example the USFS publication "Technical Report on Climate Change, Forests, Fire, Water and Fish" [Luce and others, 2012]); the USFS online library that distributes summaries of new scientific research; and newspaper coverage (including both coverage in local papers pushed out by water conservancies as well as more specialized publications).

\subsubsection{Breakdowns in the Flow of Knowledge About Tools}

Two participants responded to the question about how they stay informed by describing breakdowns in the flow of knowledge about drought information. A USFS employee in the San Juan Basin described how she has mainly found information about drought tools when she went looking for it. She was particularly frustrated that the agencies producing the information do not always get the word out about the capabilities of their products:

"[USGS outreach is] hit-and-miss. I think they do a lot of really great work, but the way I hear about those new products is more a factor of me digging around than them doing big press releases, or training courses, or sending out big email campaigns. I was telling you that the NRCS has a lot of really great modeling tools to help interpret snowpack, and runoff, and maybe it would help us fine-tune what's going on here, locally. Again, the only reason I even knew about that is because I'm working with an ex-NRCS employee, and it would be great if - I don't know, if they advertised what they could do, or what products they have, a little bit better***I guess if I had to, I could go find it, and do a lot of research, but sometimes it's just nice to be alerted what's changing, what's new that we can use. Sometimes I don't know about it until I actually have to have it***. Then I [have to] just go find it myself."

A similar frustration was expressed by a Fire Interagency Coordination Center employee, who described the disconnect experienced between the research community and those operationalizing the science: 
"Well, unfortunately I think sometimes we don't hear about some of the latest research unless you are actually attending a American Meteorological Society meeting or conference or Smoke Management meeting or conference. Unfortunately, I don't think there's good transparency from the research community to weather operations. We should say that there's a lot of room for improvement there. We don't always get phone calls sayin', "Hey, look at this new index. This is what we're tryin' to do with it. What do you think?" We don't always get those type of calls. Again, it seems like through my career***there seems to be that gap between the research community developing new techniques and actually implementing those techniques at the operational level that I work in. There's definitely some room for improvement there."

Other respondents who did not explicitly discuss a breakdown in information flow also reported discovering resources through a process of trial-and-error. For instance, a BLM administrator described how she originally found out about the tools she now uses: "I think I just did some exploring. Once I found those tools, I'd explore around for more. I do really like knowing climate information. The more I find out, I'm going to look into it more."

\subsection{What Makes a Tool Useful}

Respondents were asked how they evaluate whether or not an information source is useful to them. Past research has suggested that science is useful for decision making when it is salient to the problem at hand, technically credible, and legitimate in the sense of an unbiased public policymaking process (Cash, 2001; Cash and others, 2003; Hegger and others, 2012). Responses from water, land, and fire managers in this study highlighted that they use tools or information when it is perceived as salient and credible.

Participants described two aspects that make a tool or information source salient: relevance to decision-making and usability. First, the information must be relevant to the resource being managed and provide value to the decisions being made. A BLM employee described this relationship when asked how he judges if a tool is useful: "Whether or not it was applicable to rangeland. That's what we manage, and that's [the aspect of drought that is] of specific interest for us at the BLM." Similarly, an NPS technical specialist described valuing regionally-focused information since "it concerns the habitats that I'm directly involved with, the vegetation I'm directly involved with, the invasive species that I'm battling, managing, on a daily basis. I think it's just more applicable within our region, and within our parks." An NPS administrator summarized this aspect as "if we could successfully implement it***data is great, but if I can't make it into a meaningful management action in our park for on the ground use, I'm not sure that it's all that valuable." Similarly, a State water agency employee stated, "There has to be some benefit to [water] administration. It's looking at is [more information] saving us effort*** Or is it providing us more information so we can do a better job?***Sometimes you can put a station in. It'll save you hours a week, maybe more. Then all of a sudden that frees up time." A USFS fire manager made the same point when he described valuing information that helps him communicate with cooperators at the county or local level, who may not have the same level of technical literacy. A USFS technical specialist, however, pointed out that sometimes it is impossible to determine in advance how relevant something will be; he appreciates that lots of information crosses his desk as sometimes "something fills a hole that often I may not even know I had until I'm aware that the information exists." His comment highlights that determining salience is not necessarily as simple as asking managers what they need, since learning about new studies or tools may sometimes expand their conception of what is useful.

Second, respondents emphasized that usability (Oakley and Daudert, 2016) is an important determinant of whether something can be successfully implemented in decision making or not (and thus whether or not it is perceived as salient). A USFS fire manager pointed out that how a tool is presented affects how successfully he can evaluate its relevance for his needs:

"I think the better that a tool is presented to us through a webinar, a PowerPoint, or some kind of notes that we get, just a quick summary of it, then we can start to play with it and see what kind of use it has. I think most of us are pretty busy with our regular jobs. We've found the tools that work for us and give us the information. It's good to incorporate new things, but unless it's easy to use or easy to understand and apply, we tend to just assume, 'I don't have time for that,' and we don't incorporate it. I think a lot of it is how it's rolled out."

Another USFS technical specialist highlighted the importance of ease of use and availability of help resources when she described her frustration using a USGS tool and some advanced features on the NRCS website:

"Some of the interfaces, like if I had a crisis, and I needed a certain product to help me do some modeling, or some sort of predictive-type work*** some of those introductory pages about what this tool does can be beefed up, and really improved. I'm thinking of the USGS***I didn't think that their introductory page, talking about this modeling product, and what it can, and can't do, was really very good. I had to do a whole lot of calling around to really get the answers I needed, when I think, 'I shouldn't have to do that. It's their tool, they're putting it out there to the public, they should do a good job of explaining what it is, and its limitations.' I don't mean that to be a bad criticism, it's 
just***I get frustrated. I wish they would just put it right there on their FAQs sheet. Then with the NRCS, I got the person I'm working with that used to work with them, gave me all these links to all these different tools that you can use to model, or forecast, and, basically, use SNOTEL data. Then I just tried randomly trying to find these things without using the links that he sent. The only way I could find them was to actually click on a link in the email I was given. I think it should be way easier to stumble onto this information, than having to have somebody who knows send you a link. You should be able to browse around on their products, and just find it yourself. I thought that was difficult too."

Just like help resources, data format can shape the usability experience and thus influence whether or not a tool is perceived as salient. A BLM employee responsible for fire modeling pointed out the importance of data format to making data usable: "It doesn't mean [the information we use] is all packaged to support our fire risk. We've had to do some things in the past and build some infrastructure internally to help support some of our modeling, so to speak." For this manager, the information was less usable than it could have been (and thus less salient) by virtue of data format in which it was distributed.

Participants revealed four ways they ensure the credibility of a tool or information source: peer review, recommendations from others, funding source, and experimental adoption.

First, they emphasized they need to have confidence in the scientific integrity of the product. Respondents reported that whether or not something is peer-reviewed is one way they evaluate scientific rigor. Second, respondents also described the importance of recommendations from others to the choice of whether or not to use a given product. A BLM technical specialist indicated the State office plays an important role in her evaluation of tools, which makes sense given the hierarchical flow of information within BLM and USFS (Section 5.1): "we rely on our state office to tell us. Because they are in the business of passing on a lot of information. It would be more convincing or it would be a clearer message from them if they actually really recommended it or brought training along to help use it." A USFS technical specialist explained she evaluates "how other people have used it and what their experiences are with it." A water operator made the same point, emphasizing that he considers which of his peer operators in the region are using a given tool. Third, the same USFS technical specialist also pointed out that how a tool is funded can indicate whether it is a credible source: "If somebody else is paying for it, like extension, or universities or NRCS or something, we definitely try to take advantage of those other areas of expertise."

Fourth, respondents evaluate the credibility of tools by adopting them on an experimental basis. Respondents pointed out that new tools are often evaluated relative to existing information sources. As there are often transaction costs to switching between tools or adding additional information sources to the set an individual uses, they are more likely to make use of a new product if it offers an improvement to - rather than simply equal value to - what they are currently using. A water conservancy manager explained that his organization is likely to adopt a tool if it can provide "a better [more skillful] forecast" for the conservancy or their partners, the CBRFC. A water operator explained that because switching between tools can have consequences for how their clients perceive their actions - as "any change in water management scares the daylights out of people"-his organization only adopts new tools on an experimental basis. This cautious adoption policy ensures credibility of their models by allowing them to "pilot the idea and then check the results***then we make adjustments or we abandon the effort." A Fire Interagency Coordination Center employee made the same point, describing that tools have to be thoroughly validated before being brought into operational practice:

"In my mind, as a program manager, just because it performed one day doesn't mean we're going to take it off experimental the next day. I want to see it vetted, verified, validated, that it was a useful tool for the fire community. We'd go through an experimental phase and there would probably have to be some type of peer review or science review saying, yes, it performed well and it can be utilized as a new method."

Though their methods for evaluating credibility varied, participants agreed that tools had to be proven technically credible before being adopted.

Overall, participants indicated a desire for any information that can provide greater insight. As a water operator expressed, "the more information the better." Their comments indicate, however, that more information is actually only considered better when it is perceived as salient to the decisions being made and technically credible.

\subsection{Reasons Tools Are Not Used}

Respondents were similarly asked to describe reasons they do not make use of particular categories - precipitation and runoff; snow survey data; soil moisture; and aggregate drought indices — of available drought information sources, if they indicated they did not use these tools. Participants indicated that lack of awareness and capacity can be reasons for not making use of existing tools even if they are perceived as salient and credible. Most significantly, they emphasized that when information is not perceived as relevant it will not be used, providing a complementary perspective to the findings in Section 5.2. 


\subsubsection{Not Aware of Tools}

Not being aware of tools was mentioned as a reason for not using tools, but only by two respondents. A BLM employee in the San Juan Basin reported having never encountered the Colorado Climate Center reports, but was planning to explore them once they were mentioned in the ethnographic conversation. A USFS employee described not being aware of certain capabilities of NRCS until a former NRCS employee came to work in her office. This is a much lower level of lack of awareness than the earlier UCRB DEWS user survey found (McNie, 2014), which might be explained by successful outreach since that survey or the nature of the present research sample.

\subsubsection{Capacity Issues}

Two respondents reported that insufficient capacity (in terms of staff time, energy, and so forth) could influence a choice not to use available information, particularly when they had an existing tool that worked. A USFS technical specialist stated, "we tend to [keep] rely[ing on] it if we find one model, or one website or something that works for us***Because sometimes it is just too much information overload." In other cases, respondents were aware of information sources and reported their units needed the information for planned or future work that had not yet happened. For instance, an NPS administrator reported that she "hopes to get that information incorporated" as the park revises its fire management plan. A State employee made a similar point, stating, "interestingly enough, we spend a lot of time really trying to protect ourselves from some of the information that comes out." He described two examples: a USGS report from another region of the country that did not actually apply to his situation but still had to be commented on and a situation in which installing a streamgage on a previously-ungaged stream had improved understanding of a stream reach but also contributed to capacity issues for his office by creating an increasingly complex management challenge. Both these responses emphasize that information use can be intimately related to institutional capacity.

\subsubsection{Information Relevance}

The most common reason (mentioned by 13 participants) for not using drought information or tools was a lack of salience for the decision making needs of respondents. Respondents reported three main barriers to information relevance: not needing the information because it did not pertain to their job role, to the resources they manage, or was not available at the right temporal or spatial scales.

For some respondents, particular kinds of drought information have limited relevance because of their job role with regard to the resources being managed. Technical specialists from the USFS, BLM, and NPS reported not using information because others in their management unit are responsible for it. USFS respondents in particular reported sharp distinctions in drought responsibilities by job title. Hydrologists generally did not look at soil moisture information. The rangeland management specialist, soil scientist or ecologist often received precipitation, runoff, and snowpack information from the office or district hydrologist. Fire managers in forest offices reported relying on the RMCC Predictive Service Center for much of their information (Section 5.1). Together, these respondents painted a picture of distributed responsibility for drought management within these three land management agencies and particularly the USFS.

Information might also lack salience when respondents were not responsible for managing particular resources. An NPS administrator described little need for information about water availability on an annual basis, as the resources of that park are not water-based but consist of ecosystems where variations in water availability results in longer-term impacts to ecological health. In other words, this administrator is concerned about ecological drought impacts rather than meteorological or hydrological drought (Crausbay and others, 2017). An NPS technical specialist in another park reported minimal need for information about water availability other than as context since "it's all controlled by the Bureau of Reclamation***I don't make any management decisions on any [flow information] because it's a controlled environment. It's not anything that we can change or do anything about as far as water flow is concerned, or water availability for that matter" (Section 3.1.7).

Finally, information was not perceived as relevant if data were not available in the locations or at the temporal or spatial scales needed for respondents to make decisions, mirroring the findings of other studies (for example, Raynor, Lach, and Ingram, 2005). A BLM technical specialist reported the only soil moisture monitoring available in his area is high elevation; he would make use of lower-elevation data, but it is not available. A USFS technical specialist described data needs for long-term decision making and NEPA analysis, pointing out that short-term monitoring data "don't help a whole lot." An NRCS employee described how "locality and topography" in the mountains mean that the U.S. Drought Monitor "may not directly reflect what I'm seeing;" as a result she makes minimal use of it. These perceived gaps are described further in Section 6. 


\section{Perceived Gaps in Drought Information}

Respondents were asked to describe gaps they perceive in existing drought information and tools. Unlike indicators, information sources, and information flow, no strong pattern emerged in terms of which type of decision maker indicated which type of gap in information. Six of the 31 respondents did not provide an answer to the question about gaps in drought information. Some of these six respondents commented that they have adequate information to meet their drought decision making needs while others found the question difficult to answer on the spot, commenting that there probably are gaps they have encountered but nothing was coming immediately to mind. Table 5 summarizes the reported gaps and indicates which user type reported each gap.

Table 5. Perceived gaps in drought information by user profile type.

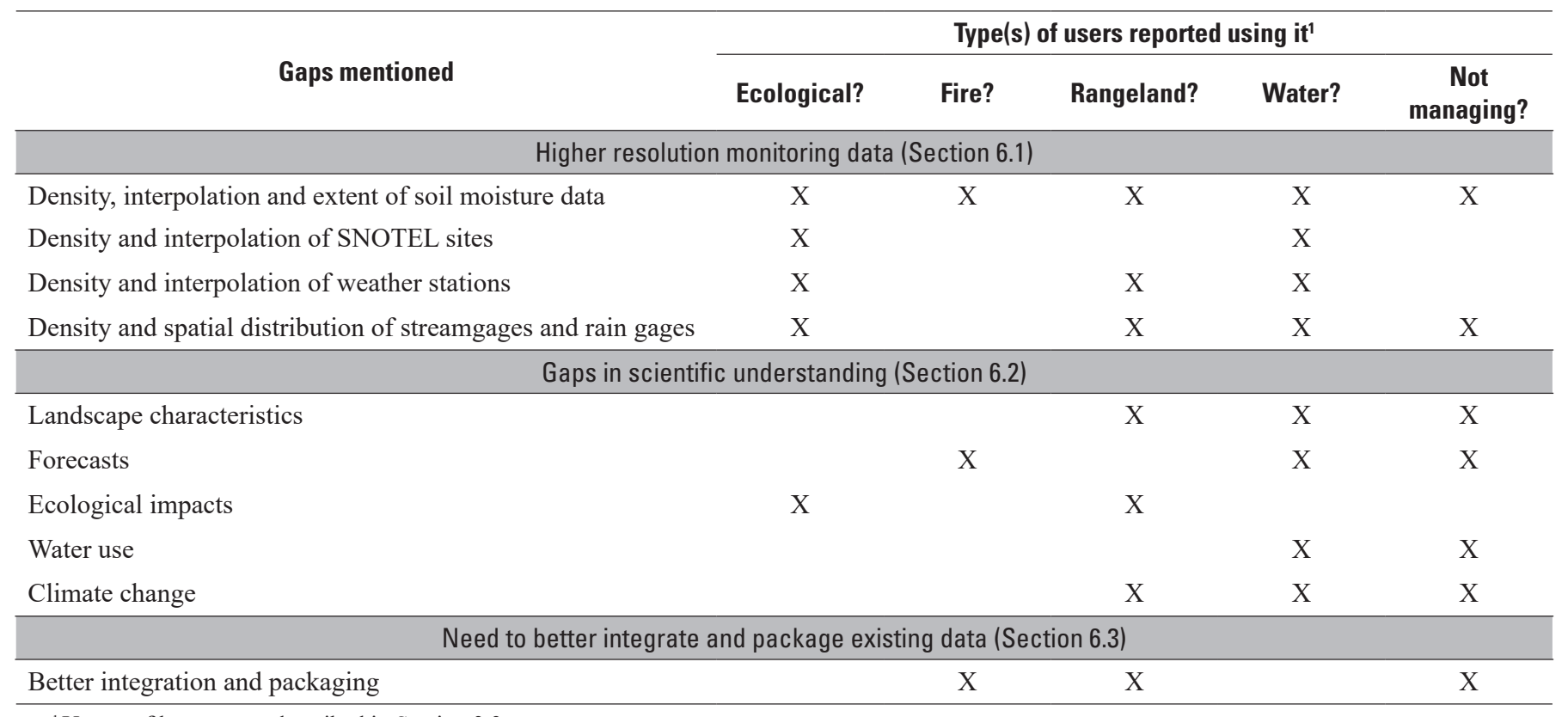

${ }^{1}$ User profile types are described in Section 3.3.

\subsection{Higher Resolution Monitoring Data}

Respondents described a number of gaps in available monitoring, including the density, interpolation, and extent of soil moisture data; the density and interpolation of SNOTEL sites; the density and interpolation of weather stations; and the density and spatial distribution of streamgages and rain gages.

The most often-mentioned information gap (discussed by 11 respondents) was the need for additional soil moisture information. A BLM employee explained that "better resolution on soil moisture data" would be helpful, but to her knowledge the information available in her area (Gunnison River Basin, Colorado Water Division 5) was not fine-scale enough to aid in her responsibilities managing vegetation. Another BLM employee discussed how difficult it is to interpolate local soil moisture from only a few monitoring stations. Four respondents working in water management highlighted the need for more soil moisture information, viewing it as a potentially helpful tool to aid in understanding how snowpack would translate into runoff. They expressed the need both to better understand the interaction between soil moisture and runoff as well as to obtain soil moisture data at the appropriate spatial resolution. A USFS employee pointed out the need to track soil moisture across a larger scale as a means to understand changing fire risk.

Five respondents described the need for better information about snowfall and snow cover. A water operator employee discussed the limitations of SNOTEL monitoring (since it is based on point measurements, which may not represent the landscape between stations) and his hope that new technologies like remote sensing and drones can provide a better means to understand the total volume of snowpack in a way that takes account of topographical variation, wind deposition, and other local variability. A USFS employee described this same challenge: "[SNOTEL and other datasets are] general information that applies to a region. It's really hard to apply it to a drainage or something like that. It gives you the idea and the general trends." An NPS employee highlighted the importance of "more and better information on winter snow and snowpack;" he predicted that it will 
How and Why Upper Colorado River Basin Land, Water, and Fire Managers Choose to Use Drought Tools (or Not)

become "even more important" in the future. A State employee commented that low-elevation sites are underrepresented in SNOTEL monitoring, though he also remarked that in most years that is not an issue and that remote sensing or other methods might be a better approach for monitoring low-elevation snow cover.

Four respondents reported a need for more localized weather information. Respondents in the San Juan Basin (Colorado Water Division 7) pointed out the lack of a weather radar location in southwest Colorado. A USFS employee linked the issue of climate forecast accuracy with mountain topography when discussing seasonal outlooks: "I'm not sure I believe in the accuracy of [a forecast more than 3 months out], just because of the mountain climate that we live in." The need for additional weather stations was also discussed by a NPS employee at Rocky Mountain National Park.

Eight participants expressed the need for additional streamgages and rain gages or identified current spatial holes in monitoring coverage. A USFS employee described the need for more streamgages on small or high altitude streams, since the existing gages

"tend to only be located on streams that have big water diversions or reservoirs on them. Then we have the vast majority of streams on the forest are from very small sub-watersheds. We don't really have a really good way to monitor, or even to model what's going on with runoff, stream temperatures, how those little stream systems are responding to monsoons or to snowpack runoff***the modeling tools that are widely available are not doing a good job with the vast majority of smaller watersheds on the forest, especially the high elevation ones."

An NRCS employee expressed that more rain gages could help with managing grazing. A BLM employee described how available precipitation data is "is not spatially very well aligned with some of the land that we manage." A Reclamation employee also highlighted the need for additional streamgages, but he saw the spatial needs as varying depending on the water project being considered, since some operations have sufficient gages and some have few or none.

\subsection{Gaps in Scientific Understanding of Drought and its Impacts}

Respondents also discussed a range of analytic gaps related to understanding how drought affects resources. These gaps fall into five general categories: landscape characteristics, forecasts, ecological impacts, water use, and climate change.

Three respondents described gaps in understanding related to hydrology and topography. An NPS employee described the need to better understand microclimates and their effect on hydrology: "you can never have enough information on [slope] aspect and temperature, with temperature distribution and solar input with the aspect." A water conservancy employee similarly highlighted the importance of understanding how snowpack translates into runoff: "we'd like to know more about how the snow pack comes off." A USFS employee indicated a gap in understanding how monsoon events affect streamflow:

"Once the monsoonal signature starts blowing in, then I go straight to the gauges. I'm just looking at what's coming off from the USGS real-time gauges, and trying to figure out how the monsoonal storms are affecting runoffs. It's really interesting. I guess I'd love to know if there are tools out there that help do a better job of interpreting, but you can get some huge monsoonal events that don't seem to move some pretty big watershed stream gauges very much. Then you'll get another monsoon that comes in, a storm, and you get big fluctuations in runoff. I'm always surprised at which ones trigger big changes in the gauges. I don't know if that has to do with the saturation of the watershed, or-I'm not really sure what's causing it, but I do pay a lot of attention to it and I would love to know how to interpret it better."

Three respondents expressed a desire for improved weather forecasting. A USFS employee expressed a wish for better short-term forecasting, though he acknowledged the difficulty of this desire: "It's almost too much to ask, but if there was a prediction model***based even on a seven-to-ten day or a month. Most if it's all real-time data and you can watch trends as they existed over the last however many weeks and months, but nothing that quantifies what could happen in the future." Similarly, a water conservancy employee expressed the desire for accurate climate forecasts that enable prediction 6 to 12 months out, but acknowledged this is probably not technically feasible. A State employee expressed a desire for more information predicted on daily time steps, to complement the forecast information received from the CBRFC, though he acknowledged "daily time step is something that most people aren't that interested in, except for administrators."

Three participants highlighted the need to understand more about the ecological impacts of drought. An NPS administrator described the need to better understand the riparian systems in her park and the "potential impacts of a very dry year" on species, especially amphibians. She pointed out that the park has minimal information about insects or invertebrates, which are likely affected by drought. A USFWS employee explained how her agency is constantly trying to "learn more about what the fish need" in terms of hydrological requirements for endangered fish in the Upper Colorado River Basin. A BLM employee described the general mismatch between existing drought indicators and resources managed by the agency: "Having been involved in developing [a BLM drought plan], I will say that a number of the [available] indicators are not based on wild lands. Most of the indicators are based on agricultural users, as well as streamflow indicators." 
Two participants discussed needs related to human water use. A water conservancy employee discussed challenges in estimating future demand for water. A State water agency employee described the need to more accurately model consumptive use of water in rural, agricultural areas.

Four respondents described gaps in understanding how climate change will shift weather and precipitation patterns in their area, as well as how that might impact resources for which they are responsible. A USFS employee described the need for more information about how climate change might affect vegetation and thus impact grazing. A Reclamation employee described a need to understand how climate change would affect runoff in Bureau projects. An employee of a water conservancy and a WAPA employee both advocated for better long-term modeling of climate impacts, including the need to understand how permafrost melting will contribute to future streamflow and runoff.

\subsection{Need to Better Integrate and Package Existing Data}

In response to the question about data gaps, four respondents discussed not gaps in monitoring or analytic information, but broader decision support needs they perceived related to how data is integrated and packaged. A BLM administrator suggested she would appreciate better integration between fire outlooks and weather or climate outlooks, since she and many of her colleagues rely on both kinds of tools given the resources for which they are responsible. A USFS fire manager mentioned the need for better guidance when two tools give a different answer: "For me there's plenty of sources out there. You may look at two sources that are presumably giving you the same answer, but they may not be, and so you have to ask yourself, well, why is one source saying one thing and why is another saying another." A Fire Interagency Coordination Center employee described the difficulty he has had obtaining and using raw data that was not suitably packaged for fire modeling, necessitating significant inhouse data processing. A WAPA technical specialist pointed out that often it would be useful to have integrated drought and flood information, as his work requires considering both high flow and low flow extremes.

\section{Conclusion-Summary of Key Findings and Implications}

This research aimed to understand the factors that influence the choices of decision makers to use or not use available drought information sources and tools. Using a case study of the National Integrated Drought Information System (NIDIS) Upper Colorado River Basin (UCRB) drought early warning system (DEWS), it investigated the following research questions:

- What decisions do managers make related to drought in the Upper Colorado region and particularly the Western Slope of Colorado? About which impacts of drought are they most concerned?

- What indicators and information products do decision makers rely on to manage for the impacts of drought in this region?

- How do decision makers find out about and choose between available drought information sources, products, and tools?

- What gaps (if any) do they perceive in currently available drought information and tools?

Section 3 described drought decision contexts, linking indicators of drought to specific decisions made by different types of respondents. Section 4 then linked indicators and decisions discussed in Section 3 to the information sources or tools on which managers rely. Section 5 described how managers find out about drought information sources and choose among the many available tools. Section 6 described how respondents perceived gaps in currently available information. This final section summarizes key findings and implications for drought early warning.

\subsection{Designing for Five Types of Drought Decision Makers with Distinct Information Needs}

Based on inductive analysis of decisions they make, indicators they rely on, information sources they use, and channels by which they find information sources (Section 3.1 and 3.2), study respondents were classified into five types of drought managers (Section 3.3):

- Ecological managers are concerned about the impact of drought on species and overall ecosystem health. They make use of a wide range of indicators, but rely heavily on local monitoring, other people, and experiential knowledge. This likely reflects the relative lack of information sources, products, and tools tailored to the impacts they care about and (or) the localized nature of ecological drought impacts. 
- Fire managers are interested in the effect of drought on wildfire risk and fire behavior during prescribed burns and suppression operations. Their key indicators of interest include temperature, relative humidity, and live and dead fuel moistures, particularly the dead fuel moisture in 1,000-hour fuels. Since fire conditions can change as quickly as a week or two, they make use of information at shorter timescales than the other groups.

- Rangeland managers manage for vegetation condition and forage production within the U.S. Forest Service (USFS), Bureau of Land Management (BLM), and Natural Resources Conservation Service (NRCS). They rely on key indicators of vegetation health and productivity, streamflow, and soil moisture. They must balance short-term productivity desires of permittees with the need to maintain the long-term ecological health of the resources they manage. They rely on a combination of local monitoring and experiential knowledge (particularly focused on soil moisture), soil moisture data, aggregate indices, and snow and precipitation information.

- Water supply managers manage or support water supply operations, though they may play a range of roles in projects. Their key indicators include reservoir levels, carryover reservoir storage, the snowpack level in winter or early spring, snow-water equivalent (SWE), runoff timing, and human demand for water. They use a wide range of snow and precipitation, weather and climate, and water supply information and tools.

- Managers who do not manage for drought as such: As described in Section 3.1.7, users in the study described three reasons they do not consider themselves to be managing for drought: (a) they have water management responsibilities that do not significantly change during drought conditions; (b) managing for drought requires a certain baseline understanding of resources and the impact that decreased water availability has on them, which some land management units do not currently have; or (c) managers do not have sufficient institutional control over water to make decisions that would influence how drought affects the resources they manage. In other words, managing for drought generally requires some understanding of or control of the link between drought exposure and response that these managers do not necessarily have, despite having roles that would seem to involve drought management.

These five groups vary in the decisions they make, the indicators they use to make these decisions, and the information sources on which they rely. What all this adds up to is distinct information needs for each of the five groups. Designing drought information products or tools without having a clear idea which group is being designed for is likely to result in less effective tools. These distinct types of drought managers provide a starting point for drought information providers to consider when defining the needs of their target audience(s).

\subsection{Supporting Users Within an "Ecosystem" of Drought Information Sources, Products, and Tools in the UCRB}

As a whole, respondents in this study depicted what can be described as a fluid ecosystem of information sources for understanding and monitoring drought indicators in the UCRB. Table 4 list more than a hundred agencies, general categories of sources, and specific information products named by users as sources of drought information. The list contains sources of varying specificity, since respondents were able to freely name their sources, rather than choosing from a prepopulated list (for example, NRCS appears as an agency when it was named at the general level by one user and the NRCS "Water and Climate Update" appears again when another user named that product specifically). As such, demonstrates the overlapping and wideranging nature of the datasets, information sources, products, and tools currently in use. This redundancy is not necessarily a bad thing, as making the same dataset available in multiple places gives users options about where and how they access it (Jeff Lukas, Western Water Assessment, oral commun., 2017).

Table 3, which depicts the information sources each individual user reported using, reinforces the point that tool use is multifaceted. Users are sophisticated in their knowledge of products and generally want as much information as possible, though a few mentioned situations where more information can complicate their jobs. Thus, they rely on suites of indicators and information to make decisions. The relatively extensive use of information by many users suggests that the UCRB DEWS and information providers in the region are already connecting users to information to a great extent, particularly for common types of drought information like precipitation information.

This description of the ecosystem of indicators and information sources has a number of implications for information providers. First, users do not always understand indicators and information sources in the same way as information providers do. Table 1, which reports the aggregate list of items named as indicators by study participants, contains many items that would technically be considered impacts according to the drought monitoring literature. This difference may reflect differing scientist and manager understandings of what constitutes an indicator, and (or) it may reflect the relative paucity of available statistically 
robust indicators to measure impacts that matter to managers, particularly for ecological impacts. If it indeed reflects a difference in definitions, information providers may want to be aware of the difference while conducting outreach. Similarly, few information sources or tools were reported as information sources for understanding ecological drought and rangeland impacts. Managers relied primarily on local-scale monitoring programs and experiential knowledge, suggesting an opportunity exists to develop robust indicators and information products aimed at understanding ecological drought.

A related point is that users do not always differentiate the products or producers of the information they use. Sometimes during the conversations users had to look up their internet bookmarks in order to describe the specific source of their information for an indicator; their identification of the tools is literally located within their internet bookmarks. McNie (2014) found the same link between the visual presentation of a tool and user recognition of it and thus chose to survey users based not only on tool name but also by presenting screenshots of tools and using common acronyms. For information providers this implies that they may need to find creative ways to reach out to or interact with users who may not even recognize they are using an information product that they do not recognize by name.

\subsection{Designing Tools Managers Choose to Use}

Respondents in this study echoed what previous research has found, namely that tools are used when information is perceived as salient and credible. Participants reported that they evaluate salience of an information source in relation to their specific drought management responsibilities. Information is used when it provides insight into the resources being managed, at relevant scales and in appropriate data formats. What this implies is that tools need to be easy to use, with accessible guidance that helps users quickly evaluate assumptions embedded in tools to determine salience in a given situation.

Respondents described challenges identifying the most useful information sources from many possible choices, leading to the use of heuristic shortcuts when evaluating the salience and credibility of new tools. Peer or agency recommendations are one important way tool credibility is evaluated. New information sources also must prove themselves to be not only as good as but significantly better than what is currently being used, as managers noted that transaction costs of switching can be high. Some ways that information providers might help overcome this transaction cost barrier in shifting between tools include obtaining peer review for new products, working with pilot users to implement tools on an experimental basis, and (or) by providing information that explicitly helps users compare between an existing source and a new one.

\subsection{Using Existing Networks to Optimize Outreach Efforts}

Distinct differences emerged when managers were asked how or from whom they would be most likely to hear about a new drought tool or information source. Water managers described a strong network and community of practice that regularly shares information across organizations. Land managers (both ecological and rangeland) reported much greater reliance on internal agency channels, either information flowing down from State or headquarters to the field or the other way around. A few respondents in the land management agencies reported not hearing about drought tools at all. Fire managers also described a strong interagency network, but one centered radially around the geographic coordination center. Fire managers reported receiving valuable drought information from fire meteorologists at RMCC. Fire managers in BLM and USFS offices then described distributing that information to other nonfire roles in BLM and USFS field offices. Other ecological and rangeland managers confirmed that fire managers in their offices can be an important source of drought information and expertise.

These findings have possible implications for how tool providers distribute or publicize drought information sources, products, and tools. The distinct differences in how different types of managers hear about tools suggest that the content and the usefulness of the information itself are not all that matter. Currently, drought tools and information reach users through existing information networks and channels. Water managers have multiple opportunities to hear about information, whether or not others in their organization are using it. Conversely, distribution to land managers generally requires collaboration and buy-in from State or headquarters offices, which serve as nodes in a fairly centralized distribution network. Information providers might consider developing formalized partnerships with the land management agency leadership and (or) exploring other channels such as place-based networks for making land managers aware of information sources, products, and tools. Current land management agency initiatives to raise the profile of drought such as the USFS regional drought workshops (https://www.fs.fed.us/managingland/sc/drought-workshops) may also contribute to the development of an interagency community of practice. 


\section{References Cited}

Agnew C., and Warren, A., 1996, A framework for tackling drought and land degradation: Journal of Arid Environments, v. 33, p. 309-20.

Beall King, A., and Thornton, M., 2016, Staying the course-Collaborative modeling to support adaptive and resilient water resource governance in the inland northwest: Water, v. 8, no. 6, p. 232, accessed March 29, 2018, at https://doi.org/10.3390/ w8060232.

Bureau of Reclamation (Reclamation), 2012, Colorado River Basin water supply and demand study: Bureau of Reclamation, accessed March 29, 2018, at https://www.usbr.gov/lc/region/programs/crbstudy/finalreport/index.html.

Bureau of Reclamation (USBR), 2015, Roster of water user organizations: Bureau of Reclamation, 19 p., accessed October 4, 2016, at https://www.usbr.gov/uc/water/users/BOR_roster_waterusers.pdf.

Cash, D.W., 2001, In order to aid in diffusing useful and practical information: Agricultural extension and boundary organizations: Science, Technology \& Human Values, v. 26, no. 4, p. 431-453, accessed March 29, 2018, at https://doi. org/10.1177/016224390102600403.

Cash, D.W., and others, 2003, Knowledge systems for sustainable development-Proceedings of the National Academy of Sciences, v. 100, no. 14, p. 8086-8091, accessed March 29, 2018, at https://doi.org/10.1073/pnas.1231332100.

Colorado Water Congress, [2018], Mission, purpose, core beliefs, and values, accessed March 2, 2018, at: http://www.cowatercongress.org/mission.html.

Colorado Water Congress, [2017], Conservancy and conservation districts of Colorado list, accessed October 21, 2017, at: http://web.cowatercongress.org/Water-Conservancy-and-Conservation-Districts-Colorado.

Colorado Water Conservation Board, 2013, Colorado drought mitigation and response plan-Prepared pursuant to Disaster Mitigation Act 2000 \& Section 409, PL 93-288, accessed March 1, 2018, at: http://cwcb.state.co.us/water-management/drought/ documents/statedroughtmitplan2013/coloradodroughtmitigationresponseplan2013.pdf.

Corbin J, Strauss A., 2008, Basics of qualitative research (3d ed.): Los Angeles, SAGE Publications, 400 p.

Crabtree, B.F. and Miller, W.L., 1999, Doing qualitative research (1st ed.): Los Angeles, SAGE Publications, 424 p.

Crausbay, S.D., and others, 2017, Defining ecological drought for the 21st century, Bulletin of the American Meteorological Society (BAMS), v. 98, no. 12, p. 2543-2550, accessed March 29, 2018, at https://doi.org/10.1175/BAMS-D-16-0292.1.

Cravens, A.E., 2016, Negotiation and decision making with collaborative software-How MarineMap "changed the game" in California’s Marine Life Protected Act Initiative: Environmental Management, v. 57, no. 2, p. 474-497, accessed March 29, 2018, at https://doi.org/10.1007/s00267-015-0615-9.

Dilling, L., and Lemos, M.C., 2011, Creating usable science-Opportunities and constraints for climate knowledge use and their implications for science policy: Global Environmental Change, v. 21 no. 2, p. 680-689, accessed March 29, 2018, at https://pubag.nal.usda.gov/catalog/418372 (doi:10.1016/j.gloenvcha.2010.11.006).

Dollison, R.M., 2010, The national map-New viewer, services, and data download: U.S. Geological Survey Fact Sheet 2010-3055, 2 p. [Also available at https://pubs.usgs.gov/fs/2010/3055/].

Geddess, B., 1990, How the cases you choose affect the answers you get-Selection bias in comparative politics: Political Analysis, v. 2, p. 131-150.

Geoffrion, A., 1983, Can MS/OR evolve fast enough?: Interfaces v. 13, p. 10-25, accessed March 29, 2018 , at https://doi.org/10.1287/inte.13.1.10.

Guest, G., MacQueen, K.M., Namey, E.E., 2011, Applied thematic analysis (1st ed): Los Angeles, SAGE Publications, 320 p.

Hegger, D., Lamers, M., Van Zeijl-Rozema, A., and Dieperink, C., 2012, Conceptualising joint knowledge production in regional climate change adaptation projects - Success conditions and levers for action: Environmental Science \& Policy, v. 18, p. 52-65, accessed March 29, 2018, at https://doi.org/10.1016/j.envsci.2012.01.002. 
Heim R.R., 2002, A review of twentieth-century drought indices used in the United States: Bulletin of the American Meteorological Society, v. 83, no. 8, p. 1149-1165.

Lopez, F.B., and Barclay, G.F., 2017, Plant anatomy and physiology, chapter 4 of Badal, S., and Delgoda, R., 2017, Pharmacognosy-Fundamentals, applications and strategies: San Francisco, Academic Press, p. 45-60, accessed March 29, 2018, at https://doi.org/10.1016/B978-0-12-802104-0.00004-4.

Luce, C., Morgan, P., Dwire, K., Isaak, D., Holden, Z., Rieman, B., 2012, Climate change, forests, fire, water, and fish-Building resilient landscapes, streams, and managers: Fort Collins, Colo.: U.S. Department of Agriculture, Forest Service, Rocky Mountain Research Station, Gen. Tech. Rep. RMRS-GTR-290, p. 207.

Lukas, J., Barsugli, J., Doesken, N., Rangwala, I., and Wolter, K., 2014, Climate change in Colorado-A synthesis to support water resources management and adaptation, in a report for the Colorado Water Conservation Board: Western Water Assessment, accessed March 29, 2018, at http://cwcb.state.co.us/public-information/publications/documents/reportsstudies/climatechangereportfull.pdf.

McKee, T., Doeskan, N., Kleist., J, Shrier, C., and Stanton, W., 2000, A history of drought in Colorado-Lessons learned and what lies ahead: Fort Collins, Colo., Colorado State University, Colorado Water Resources Research Institute Report No. 9, accessed March 29, 2018, at http://www.cwi.colostate.edu/publications/wb/9.pdf.

McKee, T., Doesken, N., and Kleist, J., 1999, Historical dry and wet periods in Colorado, Climatology Report 99-1: Fort Collins, CO, Department of Atmospheric Sciences, Colorado State University, accessed March 29, 2018, at http://climate.colostate.edu/pdfs/climo_rpt_99_1A.pdf.

McNeeley, S. M., 2014, A toad's eye view of drought—Regional socio-natural vulnerability and responses, in 2002 in northwest Colorado: Regional Environmental Change, v. 14, no. 4, p. 1451-1461, accessed March 29, 2018 , at https://doi.org/10.1007/s10113-014-0585-0.).

McNeeley, S.M., Beeton, T.A., and Ojima, D.S., 2016, Drought risk and adaptation in the interior United States-Understanding the importance of local context for resource management in times of drought: Weather, Climate, and Society, v. 8, no. 2, p. 147-161, accessed March 29, 2018, at https://doi.org/10.1175/WCAS-D-15-0042.1.).

McKee, T., Doesken, N., and Kleist, J., 1999, Historical dry and wet periods in Colorado, Climatology Report 99-1: Fort Collins, CO, Department of Atmospheric Sciences, Colorado State University, accessed March 29, 2018, at http://climate.colostate.edu/pdfs/climo_rpt_99_1A.pdf.

McNie, E., 2014, Evaluation of the NIDIS Upper Colorado River Basin drought early warning system: Boulder, CO: Western Water Assessment, accessed March 29, 2018, at http://wwa.colorado.edu/publications/reports/NIDIS_report.pdf.

Morgan, D., 2008, Snowball sampling, in Given, L., ed., The SAGE encyclopedia of qualitative research methods: Los Angeles, SAGE Publications, p. 816-817.

Morisette, J.T., and others, 2017, Crossing boundaries in a collaborative modeling workspace: Society \& Natural Resources, v. 30 no. 9, p. 1158-1167., accessed March 29, 2018 at, https://doi.org/10.1080/08941920.2017.1290178.

National Integrated Drought Information System (NIDIS), 2017, Intermountain west drought early warning system strategic plan 2017-2018, 42 p., accessed March 29, 2018, at https:/www.drought.gov/drought/sites/drought.gov.drought/files/media/ regions/rdews/UCRB/documents/IMW\%20DEWS\%20Strategic\%20Plan\%202017\%20-\%202018\%20\%281\%29.pdf.

National Integrated Drought Information System (NIDIS) [2016], What is NIDIS?, accessed October 18, 2017, at https://www.drought.gov/drought/what-nidis.

National Oceanic and Atmospheric Administration (NOAA) [n.d.], Dead Fuel Moisture: NOAA National Centers for Environmental Information, accessed October 20, 2017, at https://www.ncdc.noaa.gov/monitoring-references/dyk/deadfuelmoisture.

National Research Council, 2009, Informing decisions in a changing climate: Washington, D.C., The National Academies Press, accessed March 29, 2018, at https://doi.org/10.17226/12626.

National Research Council, 2012, Using science as evidence in public policy: Washington, D.C., The National Academies Press, accessed March 29, 2018, at https://doi.org/10.17226/13460. 
North Central Climate Science Center, 2015, North Central Climate Science Center adaptation statement of work, accessed October 18, 2017, at http://nccsc.colostate.edu/sites/default/files/NCCSC_AdaptationScience.pdf.

Oakley, N.S., Daudert, B., 2016, Establishing best practices to improve usefulness and usability of web interfaces providing atmospheric data: Bulletin of the American Meteorological Society (BAMS), v. 97, no. 2, p. 263-274, accessed March 29, 2018, at https://doi.org/10.1175/BAMS-D-14-00121.1.

Rayner, S., Lach, D., and Ingram, H., 2005, Weather forecasts are for wimps: Why water resource managers do not use climate forecasts: Climatic Change, v. 69, p. 197, accessed month, day, year, at https://doi.org/10.1007/s10584-005-3148-z.

Redmond, K.T., 2002, The depiction of drought: a commentary. Bulletin of the American Meteorological Society, 83(8), p. $1143-1147$.

Rondeau, R., B. Neely, B., Bidwell, M., Rangwala, I., Yung, L., Clifford, K., and Schulz, T., 2017, Sagebrush landscape-Upper Gunnison River Basin, Colorado, Social-Ecological Climate Resilience Project: Fort Collins, Colo., North Central Climate Science Center, 125 p., accessed March 29, 2018, at http://www.cnhp.colostate.edu/download/documents/2017/SECR_Sagebrush_Landscape_Report_4-30-2017_Final_and_Appendices.pdf.

Ryan, W, and Doesken, N., [2013], Drought of 2012 in Colorado, Fort Collins, Colo., Colorado State University, Colorado Climate Center, 7 p., accessed March 29, 2018, at http://climate.colostate.edu/pdfs/drought_2012.pdf.

State of Colorado, 2015, Colorado's water plan, 2015, accessed March 1, 2018 at: https://www.colorado.gov/pacific/cowaterplan/plan.

State of Colorado, 2016, Colorado's water plan, 2016, accessed March 1, 2018, at https:/www.colorado.gov/pacific/cowaterplan/plan.

Steinemann, A., Iacobellis, S.F., and Cayan, D.R., 2015, Developing and evaluating drought indicators for decision-making: Journal of Hydrometeorology, v. 16, no. 4, p. 1793-1803. U.S. Department of Health and Human Services, n.d. Personas: U.S. Department of Health and Human Services, accessed October 20, 2017, at https://www.usability.gov/how-to-and-tools/ methods/personas.html.

Van Loon, A.F., Gleeson, T., Clark, J., Van Dijk, A.I., Stahl, K., Hannaford, J., Di Baldassarre, G., Teuling, A.J., Tallaksen, L.M., Uijlenhoet, R., and Hannah, D.M., 2016, Drought in the Anthropocene: Nature Geoscience, v. 9, no. 2, p. 89-91.

Weiss, C., 1979, The many meanings of research utilization: Public Administration Review, v. 39, no. 5, p. 426-431, https://doi.org/10.2307/3109916.

Weiss, C.H., Murphy-Graham, E., and Birkeland, S., 2005, An alternate route to policy influence-Evidence from a study of the Drug Abuse Resistance Education (D.A.R.E.) Program: American Journal of Evaluation, v. 26, no. 1, p. 12-31.

Wenger, E., and Snyder, W., 2000, Communities of practice-The organizational frontier: Harvard Business Review (JanuaryFebruary), p. 139-145.

Wilhite, D.A., Sivakumar, M.V.K., and Wood, D.A. 2000, Early warning systems for drought preparedness and drought management in Proceedings of an Expert Group Meeting, Lisbon, Portugal, September 2000: Publisher, v. 57, p. 1-22.

Wilhite, D.A., Svoboda, M.D., and Hayes, M.J. 2007. Understanding the complex impacts of drought—A key to enhancing drought mitigation and preparedness: Water Resources Management, v. 21, p. 763-74.

Wilhite, D.A., and Vanyarkho, O., 2000. Drought: pervasive impacts of a creeping phenomenon, in Wilhite DA, ed., Drought—A global assessment: London/New York: Routledge, v. 1 and 2, no. 1, p. 245-255.

Williams, D.R., Steward, W.P., and Kruger, L.E. 2013, The emergence of place-based conservation, in Stewart, W.P. and others, eds., Place-based conservation-Perspectives from the Social Sciences, Dordrecht: Netherlands, Springer, p. 1-20, https://doi.org/10.1007/978-94-007-5802-5_1.

World Meteorological Organization (WMO) and Global Water Partnership (GWP), 2016: Handbook of drought indicators and indices: Geneva, Integrated Drought Management Programme (IDMP), Integrated Drought Management Tools and Guidelines Series 2, 46 p., accessed March 29, 2018 at http://digitalcommons.unl.edu/cgi/viewcontent.cgi?article=1118\&context=dr oughtfacpub. 


\section{Appendix 1. Codebook}

\section{Section 3. Managing for Drought in the Upper Colorado River Basin}

\begin{tabular}{|c|c|c|}
\hline Code & Subcode & Description \\
\hline \multirow[t]{6}{*}{ Decision contexts } & Agriculture or rangeland & Decisions or impacts related to agriculture, rangeland management, or grazing. \\
\hline & Ecological health & Decisions or impacts related to ecosystems, species, or ecological processes. \\
\hline & Fire management & Decisions or impacts related to wildfire suppression or prescribed burning. \\
\hline & Other & Other decisions or impacts related to drought. \\
\hline & Personnel & Decisions or impacts related to staffing and hiring \\
\hline & Planning & Decisions or impacts related to long-term planning. \\
\hline \multirow{4}{*}{ Decision timing } & Within a water year & Decisions that are made seasonally or annually, within a given water year. \\
\hline & One to five years & Decisions made looking one to five years into the future. \\
\hline & Greater than five years & Decisions made looking 5 to approximately 10 years into the future. \\
\hline & Longer term & Long term decisions, often 10 or 20 years or more in the future. \\
\hline \multirow[t]{5}{*}{ Drought indicators } & Ecological & Indicators that describe ecological status. \\
\hline & Climate change or variability & Indicators that describe long term trends associated with changing climatic conditions. \\
\hline & Snow and precipitation & Indicators that describe snow, rainfall, and runoff patterns. \\
\hline & Soil moisture & Indicators that describe soil moisture. \\
\hline & Fire & Indicators that describe wildfire risk and fire behavior. \\
\hline
\end{tabular}




\section{Section 4. Drought Information Sources and Tools}

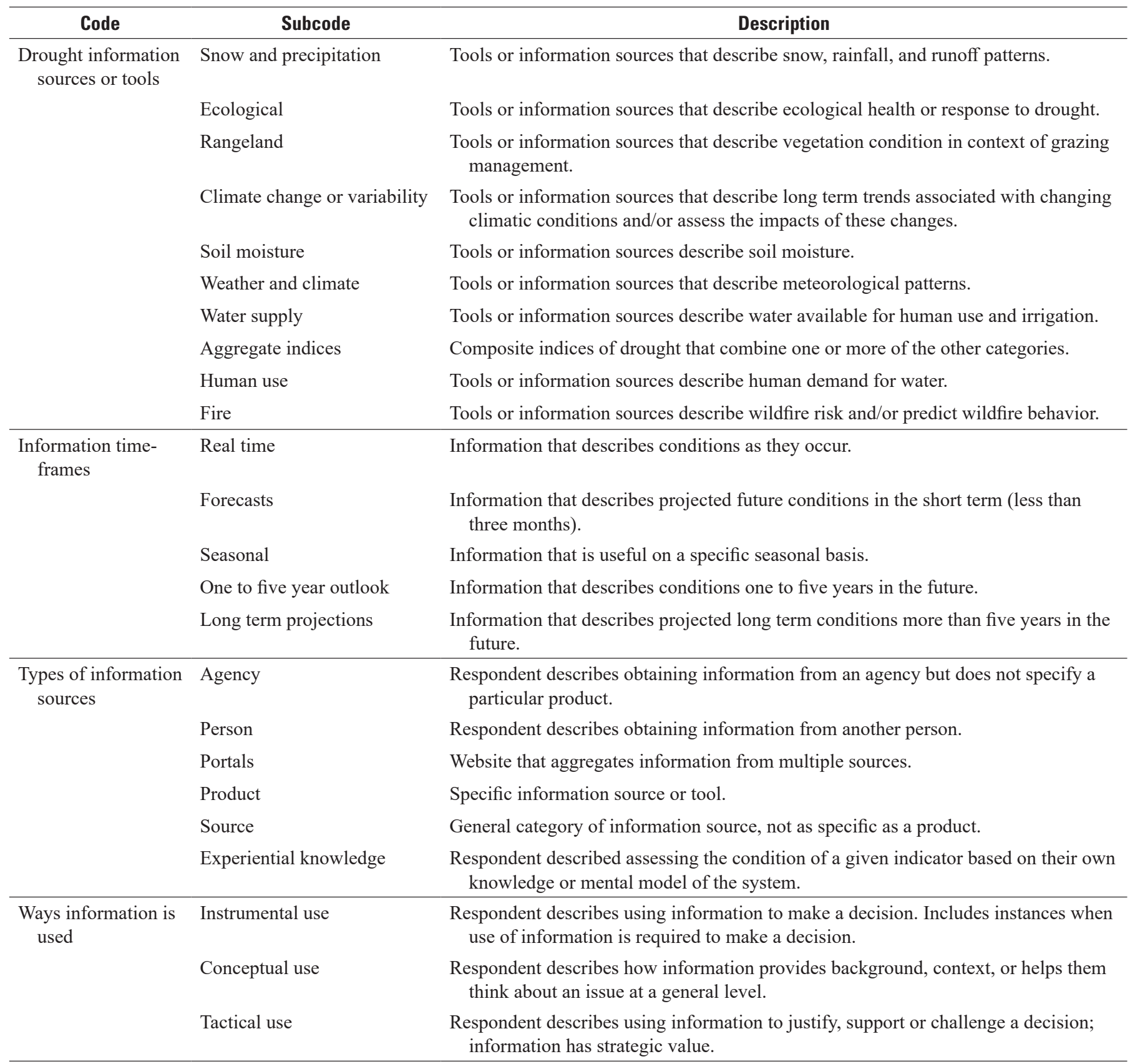




\section{Section 5. Selecting From Among Available Tools}

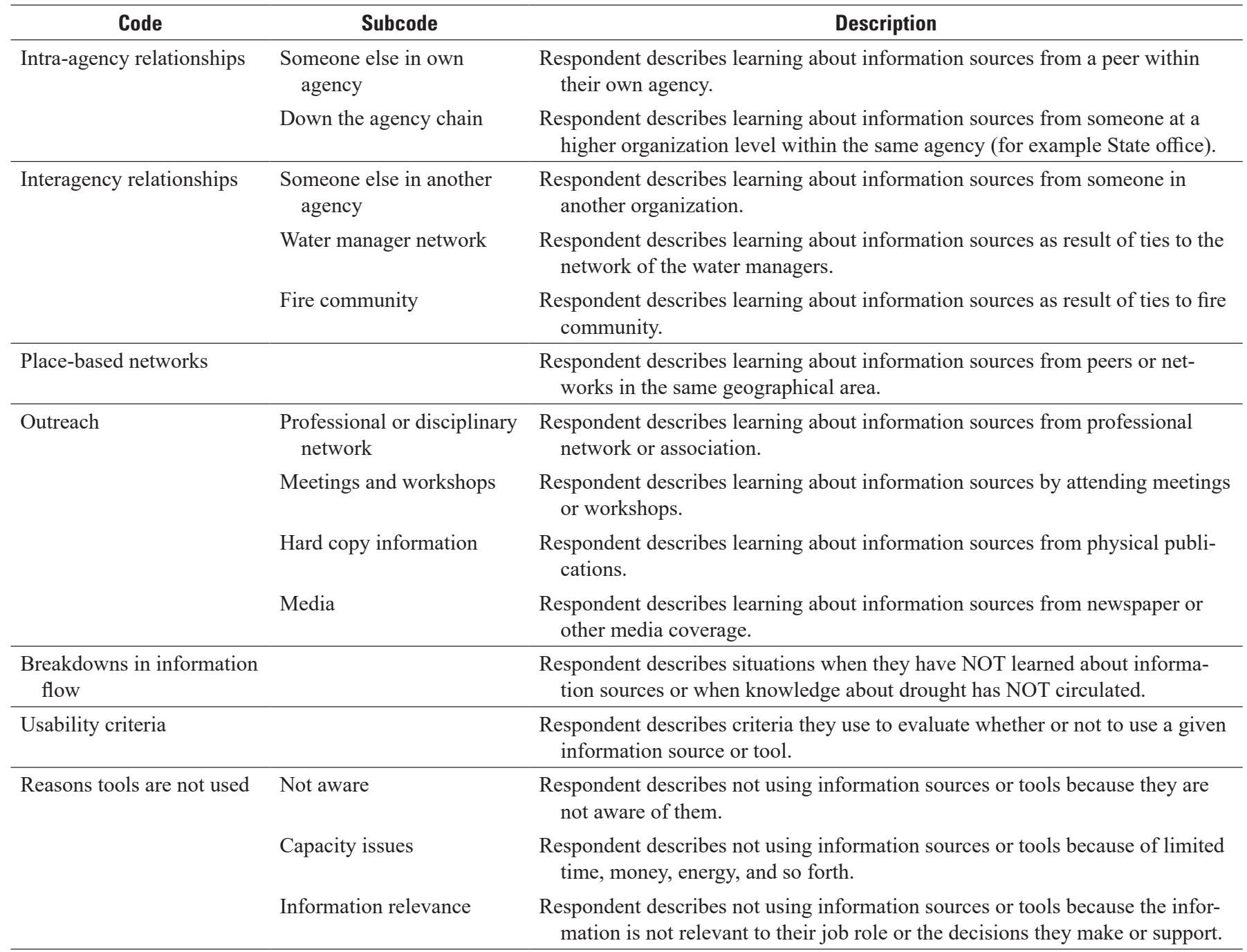




\section{Section 6. Perceived Gaps in Drought Information}

\begin{tabular}{|c|c|c|}
\hline Code & Subcode & Description \\
\hline \multirow[t]{3}{*}{ Better monitoring } & Soil moisture & $\begin{array}{l}\text { Respondent discusses need for more or better quality information about soil } \\
\text { moisture. }\end{array}$ \\
\hline & Weather & $\begin{array}{l}\text { Respondent discusses need for more or better quality information about } \\
\text { weather, weather forecasts, or short-term climate information. }\end{array}$ \\
\hline & Rainfall & $\begin{array}{l}\text { Respondent discusses need for more or better quality information about rainfall } \\
\text { or rain gages. }\end{array}$ \\
\hline \multirow[t]{3}{*}{ More analytic information } & Climate change & $\begin{array}{l}\text { Respondent discusses need for information related to effects of long term cli- } \\
\text { mate change or variability, including climate models. }\end{array}$ \\
\hline & Landscape characteristics & $\begin{array}{l}\text { Respondent discusses need for more or better quality information on relation } \\
\text { between hydrology and topography. }\end{array}$ \\
\hline & Water use & $\begin{array}{l}\text { Respondent discusses need for information about water consumption or de- } \\
\text { mand. }\end{array}$ \\
\hline No gaps or could not recall & & $\begin{array}{l}\text { Respondent reported perceiving no gaps in available information or could not } \\
\text { recall any gaps during conversation. }\end{array}$ \\
\hline Data formats & & $\begin{array}{l}\text { Respondent discusses needs related to data formats and translation of datasets } \\
\text { between technological systems. }\end{array}$ \\
\hline Integration & & Respondent discusses needs related to integrating multiple datasets together. \\
\hline
\end{tabular}


For additional information, contact::

Director, Fort Collins Science Center

U.S. Geological Survey

150 Centre Avenue, Building C

Fort Collins, CO 80526

or visit our website at: https://www.usgs.gov/fort

Publishing support provided by the Denver and West Trenton Publishing Service Centers 


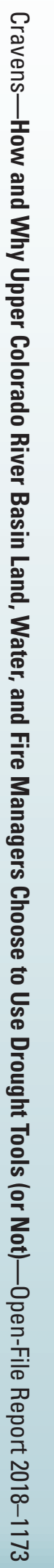

